\title{
PADRONIZAÇÃO E AVALIAÇÃO DE PCR MULTIPLEX PARA O DIAGNÓSTICO DE Escherichia coli ENTEROAGREGATIVA TÍPICA E ATÍPICA
}

Dissertação apresentada ao Programa de PósGraduação Interunidades em Biotecnologia USP/IPT/Instituto Butantan, para a obtenção do Título de Mestre em Biotecnologia. 


\section{FERNANDA BATISTA DE ANDRADE}

\section{PADRONIZAÇÃO E AVALIAÇÃO DE PCR MULTIPLEX PARA O DIAGNÓSTICO DE Escherichia coli ENTEROAGREGATIVA TÍPICA E ATÍPICA}

Dissertação apresentada ao Programa de PósGraduação Interunidades em Biotecnologia USP/IPT/Instituto Butantan, para a obtenção do Título de Mestre em Biotecnologia.

Área de concentração: Biotecnologia

Orientador: Dr. Waldir Pereira Elias Junior

Versão original 
DADOS DE CATALOGAÇÃO NA PUBLICAÇÃO (CIP)

Serviço de Biblioteca e Informação Biomédica do

Instituto de Ciências Biomédicas da Universidade de São Paulo

reprodução não autorizada pelo autor

Andrade, Fernanda Batista de.

Padronização e avaliação de PCR multiplex para o diagnóstico de Escherichia coli enteroagregativa típica e atípica / Fernanda Batista de Andrade. -- São Paulo, 2013.

Orientador: Prof. Dr. Waldir Pereira Elias Junior.

Dissertação (Mestrado) - Universidade de São Paulo. Instituto de Ciências Biomédicas. Programa de Pós-Graduação Interunidades em Biotecnologia USP/IPT/Instituto Butantan. Área de concentração:

Biotecnologia. Linha de pesquisa: Caracterização molecular de fatores de virulência de Escherichia coli diarréioge.

Versão do título para o inglês: Standardization and evaluation of multiplex PCR for the diagnostic of typical and atypical enteroaggregative Escherichia coli.

1. Escherichia coli 2. Reação em Cadeia por Polimerase 3. Diagnóstico I. Elias Junior, Prof. Dr. Waldir Pereira II. Universidade de São Paulo. Instituto de Ciências Biomédicas. Programa de PósGraduação Interunidades em Biotecnologia USP/IPT/Instituto Butantan III. Título. 
Título da

Orientador(a):
Padronização e avaliação de PCR multiplex para o diagnóstico de Escherichia coli enteroagregativa típica e atípica.

Prof. Dr. Waldir Pereira Elias Junior.

A Comissão Julgadora dos trabalhos de Defesa da Dissertação de Mestrado, em sessão pública realizada a considerou
( ) Aprovado(a)
( ) Reprovado(a)
Examinador(a): Assinatura:
Nome:
Instituição:
Examinador(a): Assinatura:
Nome:
Instituição:
Presidente: Assinatura:
Nome:
Instituição:




\section{CERTIFICADO DE ISENÇÃO}

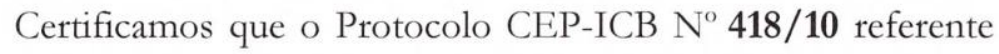
ao projeto intitulado: "Padronização e avaliação de PCR multiplex para o diagnóstico de Escherichia coli enteroagregativa típica e atípica” sob a responsabilidade de Fernanda Batista de Andrade, foi analisado na presente data pela CEUA - COMISSÃO DE ÉTICA NO USO DE ANIMAIS e pela CEPSH- COMISSÃO DE ÉTICA EM PESQUISA COM SERES HUMANOS, tendo sido deliberado que o referido projeto não envolve manipulação animal ou humana que justifique uma aprovação quanto aos princípios éticos exigidos por ambas as Comissões.

São Paulo, 21 de setembro de 2010.

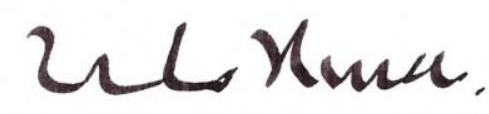

PROF. Dr. WOTHAN TAVARES DE LIMA Coordenador da CEUA - ICB/USP

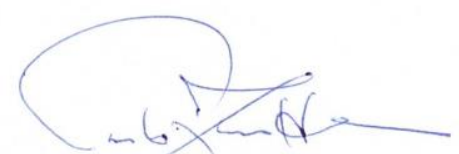

Prof. Dr. PaOlo M.A ZanOTTO Coordenador da CEPsh - ICB/USP 
Aos meus pais, pelo apoio e incentivo durante toda minha formação. 


\section{AGRADECIMENTOS}

Ao Dr. Waldir Pereira Elias Junior pela excelente orientação, incentivo e confiança.

Á Nivete Alves Batista, minha mãe sempre dedicada, companheira e carinhosa que sempre acreditou em mim e me deu todo o apoio em meus estudos e tenho certeza que estará sempre ao meu lado.

Ao Robert J.P. de Andrade, meu pai, super protetor, que com todo o seu amor, sempre quis me ver formada e continua me incentivando em continuar estudando.

Ao Cristiano R. C. Aguiar, meu companheiro, por toda a sua compreensão, admiração e incentivo.

Ao Jaime B. Fernandes, meu segundo pai, companheiro de sempre, amigo demais, dedicado, que também sempre me apoiou em meus estudos.

A todos os meus familiares principalmente a Barbara, Guilherme, Lucas, Sofia e Giane, pelo amor e carinho.

Aos colegas de laboratório, Afonso, Francielli, Claudia, Kamila, Fernando, Ludmila, Matilde, Demetria e Daniela Luz, pela ajuda sempre que necessária e as risadas que não foram poucas.

A Dr ${ }^{a}$ Roxane Piazza, por me permitir aprender ainda mais em seu laboratório.

A todos os alunos e funcionários do laboratório de Bacteriologia do Instituto Butantan.

Ao apoio financeiro do Comitê de Aperfeiçoamento de Pessoal de Nível Superior (CAPES) e da Fundação de Amparo a Pesquisa de São Paulo (FAPESP).

E por último, mas não menos importante a DEUS. 
Este trabalho foi desenvolvido no Laboratório de Bacteriologia do Instituto Butantan com auxílio financeiro da Fundação de Amparo à Pesquisa do Estado de São Paulo (Processo № 2010/19515-2) e da Coordenação de Aperfeiçoamento de Pessoal de Nível Superior. 


\section{RESUMO}

ANDRADE, F. B. Padronização e avaliação de PCR multiplex para o diagnóstico de Escherichia coli enteroagregativa típica e atípica. 2013. 86 f. Dissertação (Mestrado em Biotecnologia) - Instituto de Ciências Biomédicas, Universidade de São Paulo, São Paulo, 2013.

O patótipo de Escherichia coli diarreiogênica denominado $E$. coli enteroagregativa (EAEC) é definido pela expressão do padrão de adesão agregativo (AA) em células epiteliais cultivadas. A presença ou ausência do gene aggR, localizado no plasmídio de virulência de EAEC, define as EAEC como típicas ou atípicas, respectivamente. O diagnóstico padrão para a classificação de EAEC consiste em evidenciar o padrão AA no teste de adesão em células epiteliais cultivadas. Entretanto este teste é dispendioso, demorado e necessita de infraestrutura específica. Técnicas moleculares de diagnóstico têm sido desenvolvidas como alternativas ao teste de adesão. Esses ensaios detectam principalmente marcadores plasmidiais, não diagnosticando EAEC atípicas. O presente estudo teve como objetivo a padronização de uma PCR multiplex para o diagnóstico molecular de EAEC típica e atípica. Inicialmente os genes cromossômicos aaiA, aaiC, aaiG e aaiU foram avaliados quanto à especificidade e prevalência em EAEC. Todos foram específicos e aaiA e aaiG foram os mais prevalentes nos dois grupos de EAEC. Dessa forma, a PCR multiplex foi estabelecida incluindo esses dois genes em conjunto aos genes plasmidiais aatA e aggR. O teste foi padronizado com sucesso utilizando amostras protótipo de EAEC e seu limite de detecção foi de $125 \mathrm{ng}$ de DNA purificado. Em seguida, a reação foi avaliada em uma coleção de 403 amostras de $E$. coli de origem fecal previamente classificadas como pertencentes aos patótipos de $E$. coli diarreiogênicas ou como não patogênicas. A técnica apresentou $94,8 \%$ de sensibilidade, $94,5 \%$ de especificidade, $74,3 \%$ de valor preditivo de teste positivo e $99,1 \%$ valor preditivo de teste negativo. Além disso, permitiu um acréscimo de $60 \%$ na detecção de EAEC atípica. Dessa forma, o teste desenvolvido mostrou-se uma ferramenta sensível e específica para o diagnóstico de EAEC típica e atípica a partir de colônias de E. coli isoladas na coprocultura.

Palavras-chave: Diarreia. Escherichia coli enteroagregativa. PCR multiplex. Diagnóstico. 


\begin{abstract}
ANDRADE, F. B. Standardization and evaluation of multiplex PCR for diagnostic of typical and atypical enteroaggregative Escherichia coli. 2013. 86 p. Masters thesis (Biotechnology) - Instituto de Ciências Biomédicas, Universidade de São Paulo, São Paulo, 2013.
\end{abstract}

The diarrheagenic Escherichia coli pathotype known as enteroaggregative E. coli (EAEC) is defined by the expression of the aggregative adherence pattern (AA) on cultured epithelial cells. The presence or absence of the aggR gene, located in the EAEC virulence plasmid, defines EAEC as typical or atypical, respectively. The gold standard diagnostic for EAEC is the observation of the AA pattern in adherence tests with cultured epithelial cells. However, this assay is expensive, time consuming and needs specific laboratory infrastructure. Molecular diagnostic assays have been developed as alternatives to the adherence tests. These tests detect plasmid markers not suitable for atypical EAEC diagnosis. The present study aimed the standardization of a multiplex PCR for the molecular diagnosis of typical and atypical EAEC. Initially the chromosomal genes aaiA, aaiC, aaiG and aaiU were evaluated for specificity and prevalence in EAEC. All of them were specific and aaiA/aaiG were the most prevalent in both groups of EAEC. Thus, the multiplex PCR was established, including these two genes together with the plasmid genes aat $A$ and aggR. The test was successfully standardized using prototype EAEC strains and its detection limit was $125 \mathrm{ng}$ of purified DNA. Then, the reaction was evaluated in a collection of 403 strains of fecal $E$. coli previously classified as belonging to diarrheagenic $E$. coli pathotypes or as non-pathogenic. The technique presented $94.8 \%$ of sensitivity, $94.5 \%$ of specificity, $74.3 \%$ of positive predictive value and $99.1 \%$ of negative predictive value. Moreover, there was an increase of $60 \%$ in detecting atypical EAEC. Therefore, the test developed is a sensitive and specific tool for the diagnostic of typical and atypical EAEC employing isolated colonies of $E$. coli from stool cultures.

Keywords: Diarrhea. Enteroaggregative Escherichia coli. multiplex PCR. Diagnostic. 


\section{LISTA DE ILUSTRAÇÕES}

Figura 1 - Esquema do plasmídio de virulência pAA2 da amostra protótipo EAEC 042 com a localização dos genes que codificam fatores de virulência....

Figura 2 - Eletroforese em gel de agarose (1\%) dos produtos da PCR para detecção de aaiA, aaiC, aaiG e aail..

Figura 3 - Alinhamento das sequências de nucleotídeos parciais dos genes aaiA, aaiC, aaiG e aail

Figura 4 - Frequência dos genes cromossômicos

Figura 5 - Eletroforese em gel de agarose (1\%) do produto da PCR para detecção de aggR

Figura 6 - Alinhamento da sequência parcial de nucleotídeos do gene aggR... 54

Figura 7 - Eletroforese em gel de agarose (1\%) dos produtos da PCR

multiplex para detecção de aaiG, aatA, aaiA e aggR.

Figura 8 - Eletroforese em gel de agarose $(1 \%)$ dos produtos da PCR multiplex para detecção de aaiG, aatA, aaiA e aggR utilizando DNA purificado da amostra EAEC 042 em diversas concentrações

Figura 9 - Eletroforese em gel de agarose (1\%) dos produtos da PCR

multiplex com amostras representativas de EAEC típicas e atípicas.

Figura 10 - Avaliação da detecção de EAEC típicas e atípicas pela PCR multiplex. 


\section{LISTA DE TABELAS}

Tabela 1 - Estudos epidemiológicos sobre a etiologia da diarreia aguda com pesquisa de EAEC atípica......

Tabela 2 - Sequências dos iniciadores, tamanho dos fragmentos amplificados e ciclos de amplificação das reações de PCR para os genes aaiA, aaiC, aaiG e aaiU.

Tabela 3 - Sequências dos iniciadores, tamanho dos fragmentos amplificados e ciclo de amplificação da reação de PCR multiplex para os marcadores de virulência de EAEC.

Tabela 4 - Frequência dos genes aaiA, aaiC, aaiG e aail em amostras de E. coli diarreiogênicas, E. coli da microbiota intestinal e outras enterobactérias.

Tabela 5 - Perfis genéticos das amostras de EAEC típicas e atípicas com relação aos genes aaiA, aaiC, aaiG e aaiU.

Tabela 6 - Sequências dos iniciadores, ciclo de amplificação, concentração (pmol) dos iniciadores utilizados na PCR multiplex.

Tabela 7 - Classificação das 74 amostras de E. coli fecais positivas no ensaio PCR multiplex.

Tabela 8 - Combinações de genes detectados das 74 amostras de E. coli fecais positivas no PCR multiplex e suas classificações. 
1 INTRODUÇÃO.......................................................................... 15

1.1 Diarreia e saúde pública................................................................. 15

1.2 Escherichia coli................................................................................... 16

1.3 Escherichia coli diarreiogênica...................................................... 17

1.3.1 Escherichia coli enteropatogênica................................................ 18

1.3.2 Escherichia coli enterotoxigênica..................................................... 19

1.3.3 Escherichia coli produtora da toxina de Shiga.................................. 20

1.3.4 Escherichia coli enteroinvasora....................................................... 21

1.3.5 Escherichia coli que adere difusamente........................................... 22

1.3.6 Escherichia coli enteroagregativa................................................... 23

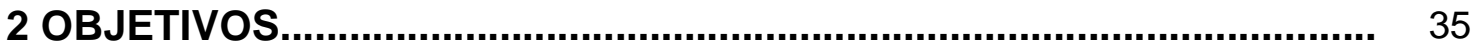

3 MATERIAL E MÉTODOS.................................................................. 36

3.1 Amostras Bacterianas.................................................................... 36

3.2 Cultivo das Amostras Bacterianas..................................................... 37

3.3 Pesquisa dos genes aaiA, aaiC, aaiG e aaiU.................................... 37

3.3.1 Reação em Cadeia da Polimerase (PCR)....................................... 37

3.3.2 Eletroforese em gel de agarose.................................................. 39

3.3.3 Sequenciamento dos amplicons................................................... 39

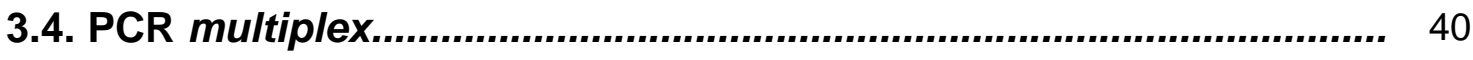

3.5. Limite de detecção da PCR multiplex........................................... 41

3.6 Validação da PCR multiplex............................................................ 42

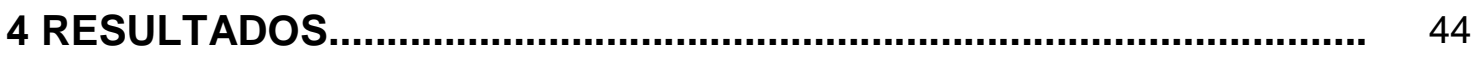

4.1 Frequência dos genes aaiA, aaiC, aaiG e aaiU............................... 44

4.2 PCR multiplex utilizando os genes aaiA, aaiG, aggR e aatA............ 52

4.3 Sensibilidade e especificidade da PCR multiplex........................... 59

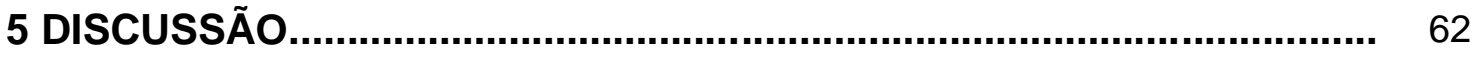

6 CONCLUSÃO............................................................................ 70 
REFERÊNCIAS 


\section{INTRODUÇÃO}

\subsection{Diarreia e saúde pública}

A doença diarreica é um importante problema de saúde pública já que no mundo ocorrem cerca de dois milhões de mortes por ano, causadas por essa doença (BLACK et al., 2010; FISCHER WALKER et al., 2012). A maior parte desses casos acomete crianças menores de cinco anos, residentes em países em desenvolvimento (PETRI et al., 2008), nos quais há falta de saneamento básico, higiene e água potável (UNITED NATIONS CHILDREN'S FUND; WORLD HEATTH ORGANIZATION, 2009; WHO, 2009).

Segundo dados do Instituto Brasileiro de Geografia e Estatística, cerca de 5 milhões de crianças brasileiras até 14 anos de idade sofrem risco de doenças, pois residem em domicílios sem estrutura de saneamento básico. Até o ano de 2011, $71,8 \%$ municípios brasileiros não possuíam uma política municipal de saneamento básico (IBGE, 2011). Sendo assim, também no Brasil a doença diarreica continua sendo um grave problema de saúde pública, importante causa de morbidade e mortalidade infantil, principalmente nas regiões norte e nordeste (OLIVEIRA; LATORRE, 2010).

A diarreia é caracterizada pela alteração no movimento de íons e de água que seguem um gradiente osmótico. Em condições normais o trato grato-intestinal tem uma grande capacidade de absorção de fluidos e eletrólitos. Diariamente cerca de $200 \mathrm{~mL}$ de fluidos são excretados nas fezes, provenientes de aproximadamente $9 \mathrm{~L}$ de fluídos absorvidos pelo trato intestinal (HODGES; GILL, 2010).

Esta patologia está associada a vírus, bactérias e outros parasitas, sendo que nos países em desenvolvimento as principais causas de infecções diarreicas são as bactérias entéricas e parasitas (HODGES; GILL, 2010). Uma variedade de bactérias têm sido escolhidas como modelos para alguns estudos, incluindo Vibrio cholerae como um clássico modelo de diarreia secretora, Clostridium difficile e Shigella spp., como agentes de diarreia inflamatória, assim como, alguns patótipos de Escherichia coli para a avaliação da alteração na absorção de íons pelas células epiteliais do intestino (HODGES; GILL, 2010). 


\subsection{Escherichia coli}

E. coli é um bacilo Gram negativo, anaeróbio facultativo, pertencente à família Enterobacteriaceae. Esse bacilo faz parte da microbiota intestinal de mamíferos e aves, além de estar presente em diversos ambientes terrestres e aquáticos (BOOP et al., 2003).

Este micro-organismo é a espécie anaeróbia facultativa mais abundante dentre os componentes da microbiota intestinal de humanos, que se estabelece logo nas primeiras horas de nascimento residindo no colón humano por toda a vida, estabelecendo assim uma relação simbiótica (FOUHY et al., 2012; KAPER; NATARO; MOBLEY, 2004; WINFIELD; GROISMAN, 2003). Existem poucos estudos relatando a relação simbiótica entre seres humanos e $E$. coli que possam justificar a sua dominância na composição da microbiota intestinal, porém, o fato dessa espécie poder utilizar o glutamato presente no colón de forma mais eficiente do que outras espécies residentes permitiria o seu sucesso nesse sítio (KAPER; NATARO; MOBLEY, 2004).

Durante a evolução, alguns clones de $E$. coli adquiriram fatores de virulência que Ihes conferiram adaptação a novos nichos e a capacidade de causar um amplo espectro de doenças (CLEMENTS et al., 2012). Esses clones patogênicos de E. coli são também conhecidos por patótipos ou patovares (CLEMENTS et al., 2012; CROXEN; FINLAY, 2010). Os vários patótipos de E. coli tendem a ser de grupos clonais que são caracterizados por compartilhar dos mesmos antígenos $O$ (sorogrupos) ou antígenos $\mathrm{O}$ e $\mathrm{H}$ (sorotipos) (BANDO et al., 2009; CAMPOS; FRANZOLIN; TRABULSI, 2004).

Os patótipos de E. coli podem causar as seguintes patologias: doença diarreica, infecção do trato urinário, meningite e sepse (CLEMENTS et al., 2012; KAPER; NATARO; MOBLEY, 2004). Desta forma as cepas patogênicas de E. coli podem causar infecções intestinais ( $E$. coli diarreiogênicas) ou extraintestinais. Estas últimas também são conhecidas por ExPEC (KAPER; NATARO; MOBLEY, 2004; RUSSO; JOHNSON, 2000). 


\subsection{Escherichia coli diarreiogênicas}

As E. coli diarreiogênicas (DEC), são classificadas em seis categorias, ou patótipos, de acordo com características específicas baseadas em seus mecanismos de patogenicidade, padrões distintos de adesão em células epiteliais cultivadas ou síndromes clínicas que causam. A classificação atual define os seguintes patótipos: E. coli enteropatogênica (EPEC), E. coli enterotoxigênica (ETEC), E. coli enteroagregativa (EAEC), E. coli enterohemorrágica (EHEC), E. coli enteroinvasora (EIEC) e E. coli que adere difusamente a células epiteliais (DAEC) (CLEMENTS et al., 2012; CROXEN; FINLAY, 2010).

Embora esta classificação seja mundialmente aceita, recentes avanços no conhecimento da patogenicidade de DEC mostraram que algumas categorias incluem micro-organismos distintos, tais como EPEC e EAEC que foram subdivididas em típicas e atípicas (TRABULSI; KELLER; GOMES, 2002; HARRINGTON; DUDLEY; NATARO, 2006) e as EHEC que passaram a fazer parte de uma subcategoria de E. coli produtora da toxina Shiga, ou STEC (NGUYEN; SPERANDIO, 2012).

Recentemente uma nova classificação foi proposta por Clements et al. (2012) na qual as $E$. coli são divididas em oito patótipos: os seis anteriormente descritos acrescidos de E. coli aderente invasiva (AIEC), associada com a doença de Crohn, e E. coli enteroagregativa produtora da toxina Shiga (STEAEC), responsável por um grande surto diarreico em 2011 na Europa.

Outro potencial patógeno de DEC proposto é denominado de E. coli citodestacante ou Cell Detaching E. coli (CDEC), caracterizadas pela atividade hemolítica e capacidade de destacar monocamadas de células epiteliais em cultura (GUNZBURG et al., 1993; OKEKE, 2009). Porém, CDEC ainda não foi significativamente associada a casos de diarreia (KNUTTON et al., 2001; MARQUES et al., 1995; OKEKE et al., 2000). 


\subsubsection{Escherichia coli enteropatogênica}

E. coli enteropatogênica (EPEC) foi o primeiro patótipo de DEC descrito e permanece como importante causa de diarreia infantil em países em desenvolvimento (OCHOA et al., 2008).

As EPEC são caracterizadas pela capacidade de causar uma lesão histopatológica no epitélio intestinal denominada lesão attaching-effacing, (lesão $A / E)$, característica histopatológica intestinal da infecção por EPEC. A lesão A/E é decorrência da aderência bacteriana inicial e íntima às células da mucosa intestinal, a qual induz mudanças no citoesqueleto da célula hospedeira, formando estruturas semelhantes a um pedestal, levando à destruição das microvilosidades (MOON et al., 1983; FRANKEL; PHILLIPS, 2008). A reorganização do citoesqueleto altera a morfologia e fisiologia normal da região apical das células, o que leva a perda das microvilosidades intestinais e suas funções, culminando com a diarreia (CROXEN; FINLAY, 2010; KAPER; NATARO; MOBLEY, 2004).

A lesão $A / E$ é desencadeada por proteínas codificadas em uma ilha de patogenicidade denominada LEE (locus of enterocyte effacement) que também está presente em EHEC (McDANIEL et al., 1995).

Posteriormente à definição de EPEC, houve a proposta de subdivisão das amostras pertencentes a esse patótipo em dois grupos: EPEC típica e atípica (KAPER, 1996). Essa classificação foi adotada e segue em uso (HERNANDES et al., 2009; TRABULSI; KELLER; GOMES, 2002). EPEC típica compreende as bactérias que apresentam o plasmídio EAF (EPEC adherence fator) e EPEC atípica as que não apresentam esse plasmídio e diferem das EHEC por não produzirem a toxina Shiga (Stx) (KAPER, 1996). Esse plasmídio alberga os genes envolvidos na montagem e expressão de uma adesina fimbrial, BFP (bundle-forming pilus), envolvida na patogênese de EPEC típica, que permite a aderência interbacteriana e possibilita a adesão às células epiteliais (GIRÓN et al., 1993; VIDAL et al., 2007).

Quando em contato com células epiteliais em cultura, amostras de EPEC típicas apresentam um padrão característico de adesão denominado adesão localizada (AL), no qual as bactérias estão aderidas em grupos compactos, em um 
ou mais pontos na superfície da célula epitelial (SCALETSKY; SILVA; TRABULSI, 1984).

Este fenótipo é decorrente da expressão da fímbria BFP (GIRÓN et al., 1993), ausente em EPEC atípica (HERNANDES et al., 2009). Por essa razão, amostras de EPEC atípica expressam frequentemente o padrão de adesão localizada-like (AL-L), onde as bactérias aderem em grupos bastante esparsos, em um ou mais pontos da superfície da célula hospedeira (RODRIGUES et al., 1996).

Além do padrão $A L-L$, os padrões difuso (AD) e agregativo (AA) de adesão também são observados em algumas amostras de EPEC atípica (HERNANDES et al., 2006; TRABULSI; KELLER; GOMES, 2002). No padrão AD as bactérias aderem difusamente por toda a superfície celular (SCALETSKY; SILVA; TRABULSI, 1984), enquanto no padrão AA as bactérias estão aderidas umas às outras, tanto na superfície celular como na lamínula, formando agregados semelhantes a tijolos empilhados (NATARO et al., 1987). Embora AD e AA sejam a priori os padrões que definem amostras de DEC como DAEC e EAEC, respectivamente (NATARO; KAPER, 1998), amostras que albergam a região LEE, mas expressam esses padrões são classificadas como EPEC (HERNANDES et al., 2006).

EPEC continua sendo uma das principais causas de diarreia infantil em países em desenvolvimento (HERNANDES et al., 2009; OCHOA; CONTRERAS, 2011). Entretanto, inúmeros estudos epidemiológicos recentes têm mostrado que EPEC atípica é mais frequente do que EPEC típica, situação inversa ao conhecido nas décadas de 1970 a 1990 (TRABULSI; KELLER; GOMES, 2002). EPEC atípica tem sido relacionada a casos de diarreia aguda e persistente, especialmente em crianças com menos de dois anos de idade, além de surtos de diarreia em países desenvolvidos (AFSET et al., 2004; HERNANDES et al., 2009; KAPER; NATARO; MOBLEY, 2004; NGUYEN, et al., 2006; SCALETSKY et al., 1999).

\subsubsection{Escherichia coli enterotoxigênica}

E. coli enterotoxigênica (ETEC) é o agente etiológico mais frequente da diarreia do viajante e de diarreia aguda em crianças e adultos em zonas endêmicas. 
Causa diarreia aquosa que pode variar de uma doença leve a uma doença grave e severa (ISIDEAN et al., 2011; QADRI et al., 2005).

As bactérias pertencentes a essa categoria têm como característica a produção de duas enterotoxinas denominadas termo-lábil e termo-estável. As amostras de ETEC podem expressar uma dessas toxinas ou ambas (KAPER; NATARO; MOBLEY, 2004; TURNER et al., 2006).

A toxina termo-lábil ativa a adenilato ciclase provocando um aumento considerável na produção de AMP cíclico (cAMP) e, consequentemente, o aumento na síntese de prostaglandinas, pelas células intoxicadas e um excessivo acúmulo de sal e água no lúmen intestinal causando a morte celular, assim como, os sintomas da diarreia aquosa causada por ETEC (SPANGLER, 1992). A toxina termoestável causa a elevação dos níveis de GMP cíclico, com consequente desequilíbrio no metabolismo hidrossalino causado pela ativação de guanilato ciclase (TURNER et al., 2006).

Além dessas toxinas, ETEC apresenta diversos fatores de colonização, que são estruturas adesivas da superfície bacteriana (ISIDEAN et al., 2011). Elas permitem que esse patótipo colonize a mucosa do intestino, viabilizando a expressão das toxinas (GAASTRA; SVENNERHOLM, 1996; QADRI et al., 2005).

\subsubsection{Escherichia coli produtora da toxina Shiga}

E. coli produtora da toxina Shiga (STEC) é um importante enteropatógeno em todo o mundo, podendo causar diarreia aguda, diarreia sanguinolenta e complicações de grande importância clínica, como a colite hemorrágica ou a síndrome hemolítica urêmica (CLEMENTS et al., 2012; HUNT, 2010). Essas bactérias produzem uma potente toxina denominada toxina Shiga (Stx), responsável pela diarreia sanguinolenta e desenvolvimento da síndrome hemolítica urêmica, ou SHU (BERGAN et al., 2012).

O gado bovino e outros ruminantes são reservatórios naturais de STEC, sendo a principal via de contaminação o consumo de água ou alimentos contaminados com as fezes desses animais. Dessa forma, as infecções causadas por STEC são consideradas zoonoses (KARMALI; GANNON; SARGEANT, 2010). 
Há uma subcategoria de STEC, denominada EHEC que também causa a SHU, sendo que a diarreia provocada por esse patótipo pode ser sanguinolenta ou não (KAPER; NATARO; MOBLEY, 2004; RILEY et al., 1983). O que difere as EHEC das demais STEC é que EHEC possui a ilha de patogenicidade LEE, desse modo, é capaz de causar a lesão $A / E$, semelhante à induzida por EPEC, além de estar intimamente associada com a SHU (CROXEN; FINLAY, 2010; NGUYEN; SPERANDIO, 2012).

O principal fator de virulência de EHEC é a toxina Stx, é conhecida também como verotoxina (NATARO; KAPER, 1998). Stx é constituída por cinco subunidades $B$ idênticas e uma única subunidade $A$. As subunidades $B$ são responsáveis pela ligação ao receptor Gb3, que é expresso amplamente nas células endoteliais glomerulares. Após a endocitose mediada pelo receptor, a subunidade A é internalizada e ativada, levando à depuração de adenosinas específicas no RNA ribossômico 28S, que resulta na inibição irreversível do alongamento da proteína e apoptose das células endoteliais (BERGAN et al., 2012). A toxina Stx é produzida no colón e transportada pela corrente sanguínea até os rins, onde irá causar danos nas células endoteliais renais e obstruir a microvasculatura, através da combinação da toxicidade direta e indução local da produção de quimiocinas, resultando assim na inflamação renal que pode levar ao desenvolvimento de SHU (POLITO; KIRZTAJN, 2010; NGUYEN; SPERANDIO, 2012).

\subsubsection{Escherichia coli enteroinvasora}

Escherichia coli enteroinvasora (EIEC) é o único patótipo de E. coli com patogênese intracelular, capaz de invadir e se replicar em células epiteliais e macrófagos, induzindo a apoptose nessas células. Além disso, pode elaborar uma ou mais enterotoxinas importantes na patogênese da diarreia causada por este patógeno (CROXEN; FINLAY, 2010).

O mecanismo de patogenicidade de EIEC consiste de cinco etapas: penetração na célula epitelial, lise do vacúolo endocítico, multiplicação bacteriana, movimentação no citoplasma e passagem para as células adjacentes (KAPER; NATARO; MOBLEY, 2004; PARSOT, 2005). Quando a infecção é severa essa 
sequência de eventos leva a uma forte reação inflamatória, causando possíveis ulcerações gerando um quadro de disenteria, com a presença de sangue e muco nas fezes (COSSART; SANSONETTI, 2004), porém algumas vezes EIEC causa somente diarreia aquosa indistinguível de outras E. coli patogênicas (KAPER; NATARO; MOBLEY, 2004; NATARO; KAPER, 1998).

Os genes necessários para este complexo mecanismo de patogenicidade estão albergado em um plasmídio de virulência presente também em Shigella spp. (JOHNSON; NOLAN, 2009). Este plasmídio codifica um sistema de secreção do tipo III que resulta múltiplos efeitos da patogenicidade de EIEC e de Shigella, secretando uma variedade de proteínas entre elas: IpaA, IpaB, IpaC, IpgD, que medeiam diversos eventos como sinalização das células epiteliais, o rearranjo do citoesqueleto, a absorção celular, a lise de vacúolos endocíticos, entre outras ações (CLEMENTS et al., 2012). Dessa forma, EIEC e Shigella spp. compartilham genes de virulência e mecanismos de patogenicidade (COSSART; SANSONETTI, 2004).

\subsubsection{Escherichia coli que adere difusamente}

E. coli que adere difusamente a células epiteliais (DAEC) é caracterizada por apresentar o padrão de aderência difusa (AD) em culturas de células HeLa ou HEp-2 (NATARO et al., 1987; SCALETSKY; SILVA; TRABULSI, 1984).

A associação epidemiológica entre DAEC e diarreia aguda é controversa, uma vez que a maioria dos estudos epidemiológicos sobre a etiologia da diarreia aguda não associa DAEC à diarreia (GOMES et al., 1998; NATARO et al., 1987; RODRIGUES et al., 2002). Por outro lado, parece existir correlação quando as populações são estratificadas por faixas etárias (GIRÓN et al., 1991; SCALETSKY et al., 2002; SPANO et al., 2008).

A patogênese da diarreia causada por esse patótipo permanece desconhecida, porém alguns potenciais fatores de virulência já foram identificados em DAEC (BENZ; SCHMIDT, 1992; BILGE et al., 1989; GUIGNOT et al., 2007; LE BOUGUÉNEC; SERVIN, 2006; TADDEl et al., 2003). 
Tem sido relatada a presença de adesinas fimbriais (F1845) e não fimbriais (AIDA-1, Sfa e P) em DAEC (LE BOUGUÉNEC; SERVIN, 2006), entretanto o real papel das mesmas na patogênese da diarreia ainda não está definido.

A proteína autotransportadora secreted autotransporter toxin (Sat) foi identificada em DAEC isoladas de casos de diarreia. Foi demonstrado ainda que Sat é mais comumente detectada em DAEC isoladas de crianças com diarreia do que de crianças sadias (GUIGNOT et al., 2007; TADDEl et al., 2003).

Estudos têm demonstrado que amostras de DAEC são capazes de induzir a extensão de projeções longas e finas da superfície celular, que envolve a bactéria e a protege da ação de antimicrobianos (COOKSON; NATARO, 1996; YAMAMOTO et al., 1992).

\subsubsection{Escherichia coli enteroagregativa}

Escherichia coli enteroagregativa (EAEC) é definida como o patótipo de DEC que expressa o padrão de adesão agregativa (AA) em células epiteliais cultivadas (NATARO; KAPER, 1998). No padrão AA as bactérias formam agregados em uma configuração que lembra tijolos empilhados. Essa adesão ocorre na superfície das células e também na superfície da lamínula formando arranjos que remetem aos favos de uma colmeia (NATARO et al., 1987).

Esse padrão foi descrito durante a análise da aderência em células HEp-2 de amostras de $E$. coli isoladas em um estudo epidemiológico sobre a etiologia da diarreia aguda no Chile (NATARO et al., 1987). Nesse estudo, os autores foram capazes de subdividir o fenótipo anteriormente descrito como aderente difuso (SCALETSKY; SILVA; TRABULSI, 1984) em duas classificações: aderência agregativa ( $A A$ ) e a aderência difusa (DA) propriamente dita. A alta prevalência do padrão $A A$ em $E$. coli de crianças com diarreia, levou à proposição do novo patótipo de DEC, denominado EAEC (NATARO; KAPER, 1998).

Dentre os agentes etiológicos bacterianos da diarreia EAEC se destaca como um enteropatógeno emergente ao redor do mundo (HARRINGTON; DUDLEY; NATARO, 2006). Nos últimos anos tem sido relatada a associação entre EAEC e diarreia aguda na infância, tanto em países em desenvolvimento (ARAUJO et al., 
2007; BUERIS et al., 2007; NGUYEN et al., 2005; OKEKE et al., 2003; SCALETSKY et al., 2002), como desenvolvidos (COHEN et al., 2005; NATARO et al., 2005; ROBINS-BROWNE et al., 2004).

No Brasil, vários estudos epidemiológicos recentes sobre a etiologia da diarreia aguda têm apontado EAEC como o patótipo de DEC mais prevalente (ARAUJO et al., 2007; BUERIS et al., 2007; GARCIA; SILVA; DINIZ, 2011; MORENO et al., 2010; PEREIRA et al., 2007; REGUA-MANGIA et al., 2004; RODRIGUES et al., 2002; SCALETSKY et al., 2002).

Vários surtos de diarreia em países desenvolvidos foram causados por cepas de EAEC e associados à ingestão de alimentos ou água contaminados (HARADA et al., 2007; ITOH et al., 1997; SMITH; CHEASTY; ROWE, 1997). Em 2011 um grande surto de diarreia que acometeu vários países da Europa foi causado por uma amostra de E. coli (sorotipo O104:H4) produtora de toxina Stx2 (BIELASZEWSKA et al., 2011). O sequenciamento do genoma dessa amostra revelou que se tratava de uma EAEC que adquiriu genes do fago que codifica Stx2 (RASKO et al., 2011). Esse surto foi associado ao consumo de alimento contaminado e teve graves consequências médicas, devido ao grande número de pacientes hospitalizados e que desenvolveram a SHU (MUNIESA et al., 2012).

A ingestão de alimentos contaminados talvez seja uma forma de infecção por EAEC, pois já houve relatos em países desenvolvidos da ocorrência de diversos surtos provocados por essa via (ITOH et al., 1997; HARADA et al., 2007; SMITH; CHEASTY; ROWE, 1997). No Brasil EAEC foi detectada em leite de mamadeiras de lactantes de baixo nível sócio econômico que haviam sido atendidos em ambulatórios de hospitais públicos, o que favorece a possibilidade de infecção por EAEC a partir de alimentos contaminados (MORAIS; GOMES; SIGULEM, 1997).

EAEC está fortemente associada à diarreia persistente, ou seja, com duração maior que 14 dias (BHAN et al., 1993; CRAVIOTO et al., 1991; FANG et al., 1995; LIMA et al., 1992), o que pode levar a má nutrição, problemas de crescimento e de desenvolvimento cognitivo (NAVARRO-GARCIA et al., 2010).

Vários estudos sobre a etiologia da diarreia do viajante, que é aquela que afeta indivíduos residentes de países desenvolvidos que visitam países em 
desenvolvimento, apontam a alta prevalência de EAEC como agente desses casos (ADACHI et al., 2002; JIANG et al., 2002; MOHAMED et al., 2007).

EAEC esta também associada com diarreia crônica em pacientes com Síndrome da Imunodeficiência Adquirida, ou SIDA (BERNIER; GOUNON; LE BOUGUÉNEC, 2002; MATHEWSON et al., 1995; NAVARRO-GARCIA; ELIAS, 2011; SAMIE et al., 2007).

De fato, Huang et al. (2006) demonstraram através de um estudo de metaanálise da literatura entre 1987 e 2006 que EAEC esteve estatisticamente associada à diarreia aguda e persistente em países desenvolvidos e em desenvolvimento, à diarreia em pacientes com HIV (Human Imunodeficiency Virus) e à diarreia do viajante.

Os sintomas mais comuns relatados na infecção por EAEC são diarreia aquosa com ou sem sangue e muco, dor abdominal, náusea, vômito e pouca febre. A diversidade de sintomas clínicos na infecção por esse patótipo pode ser devido à heterogeneidade entre os isolados de EAEC, à dose infecciosa e a fatores de susceptibilidade genética do hospedeiro, assim como, à reposta imune (HARRINGTON, DUDLEY; NATARO, 2006; HUANG et al., 2006).

Essa heterogeneidade ficou bastante evidente em um estudo com voluntários humanos que receberam inóculos por via oral de quatro amostras de EAEC, sendo que apenas uma delas causou diarreia (NATARO et al., 1995). Essa amostra denominada EAEC 042 (sorotipo O44:H18) passou então a ser amplamente caracterizada e considerada como protótipo (NAVARRO-GARCIA; ELIAS 2011).

Várias adesinas, toxinas e proteínas envolvidas em algum processo de virulência têm sido identificadas em EAEC, mas a prevalência dos genes que codificam esses marcadores é bastante variável e nenhum deles foi encontrado em todas as amostras (BOUZARI; JAFARI; ZAREPOUR, 2005; CZECZULIN et al., 1999; ELIAS et al., 2002; GIOPPO et al., 2000; JENKINS et al., 2006a; MOHAMED et al., 2007; OKEKE et al., 2003; PIVA et al., 2003; ZAMBONI et al., 2004). Essa complexidade não permitiu que a patogênese da diarreia causada por esse patótipo fosse totalmente esclarecida (HARRINGTON; DUDLEY; NATARO, 2006).

Apesar da complexidade e heterogeneidade de EAEC, um modelo com três estágios foi proposto para a patogênese da diarreia: (a) o primeiro estágio envolve a 
aderência na mucosa intestinal e na camada de muco através de adesinas fimbriais e/ou afimbriais; (b) no segundo estágio há a formação de abundante biofilme e aumento da produção de muco pelos enterócitos, o que pode promover uma colonização persistente e má absorção de nutrientes; (c) por último há a secreção de toxinas e outras proteínas de virulência levando à indução de resposta inflamatória, havendo alteração na mucosa e na secreção intestinal (HARRINGTON; DUDLEY; NATARO, 2006; HUANG; DUPONT, 2004; NAVARRO-GARCIA, et al., 2010).

Diversos fatores de virulência de EAEC são codificados por genes localizados no plasmídio ou no cromossomo das amostras consideradas protótipo. Dentre esses fatores estão diversas adesinas, toxinas, proteínas secretadas e sideróforos, identificados principalmente na EAEC 042, cujo genoma completo já foi sequenciado (CHAUDHURI et al., 2010; NAVARRO-GARCIA et al., 2010).

Devido à associação do fenótipo de aderência agregativa com plasmídios e ao grande número de potenciais fatores de virulência plasmidiais, esses plasmídios são conhecidos por plasmídios de virulência de EAEC e denominados pAA (HARRINGTON; DUDLEY; NATARO, 2006)

O plasmídio pAA1 presente na amostra protótipo EAEC 17-2 (sorotipo O3:H2) apresenta cerca de $100 \mathrm{~kb}$. Essa amostra foi a primeira EAEC a ser estudada geneticamente com relação às propriedades de aderência, o que permitiu a identificação da primeira fímbria de adesão agregativa (AAF/I) codificada no pAA1. Nesse plasmídio estão localizados os genes da biogênese de AAF/l, o regulador transcricional AggR, toxina EAST-1, proteína dispersina e seu sistema de secreção do tipo ABC (NATARO et al., 1992; NATARO et al.,1994; SAVARINO et al., 1991).

O plasmídio pAA2 presente na amostra EAEC 042 também apresenta aproximadamente $100 \mathrm{~Kb}$ e codifica muitos fatores de virulência bem caracterizados, tais como as toxinas Pet e EAST-1, a fímbria de aderência agregativa AAF/II, o regulador transcricional AggR, a proteína dispersina, seu sistema de secreção do tipo ABC e as proteínas Shf, Virk e CapU (CHAUDHURI et al., 2010; CZECZULIN et al., 1999). A figura 1 apresenta um esquema do pAA2 e a localização desses genes de virulência. 


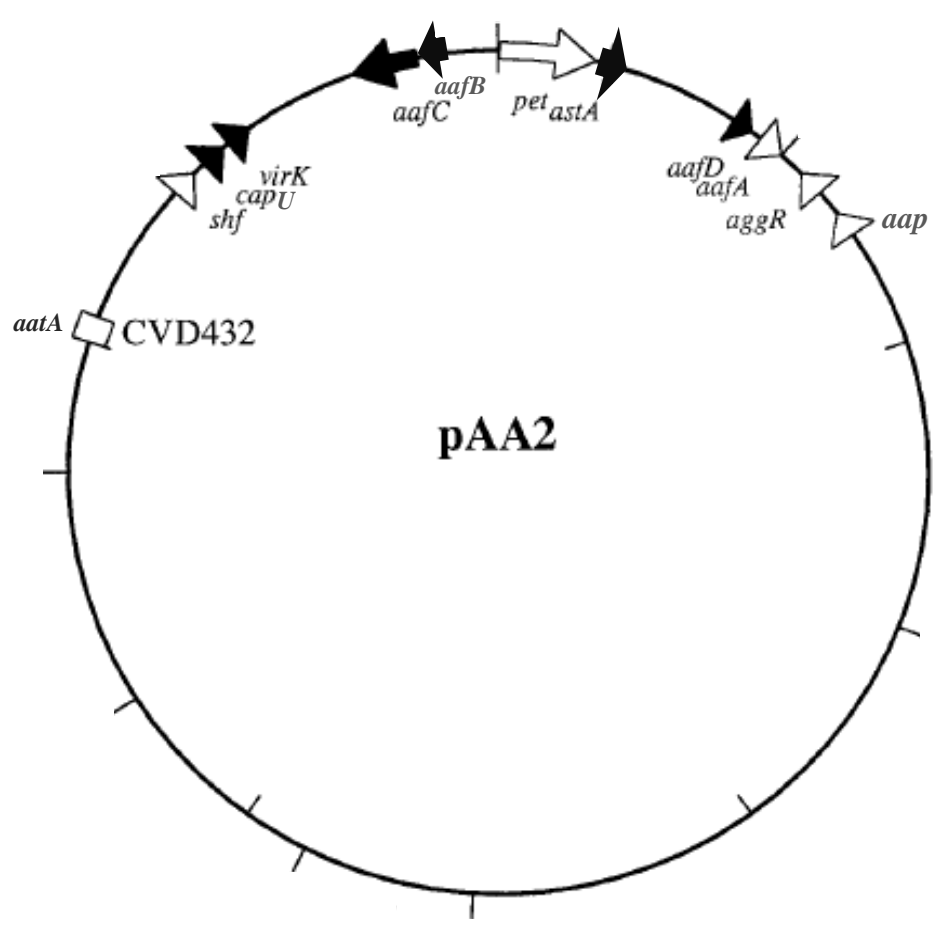

Figura 1 - Esquema do plasmídio de virulência pAA2 da amostra protótipo EAEC 042 com a localização dos genes que codificam fatores de virulência. aafABCD, genes da biogênese da fímbria $A A F / I I ; a g g R$, codifica a proteína AggR, ativadora transcricional de genes de virulência plasmidiais e cromossômicos; astA, codifica a toxina EAST-1; pet, codifica a toxina Pet; aap, codifica a proteína dispersina; CVD432, fragmento sonda para diagnóstico de EAEC correspondente a parte do gene aatA; operon shf-capU-virK, codificam as proteínas Shf, CapU e VirK, respectivamente.

Fonte: Adaptado de Chaudhuri et al., 2010 e Czeczulin et al., 1999.

Estudos sobre a patogênese de EAEC são focados no regulador transcricional AggR e a expressão de vários fatores de virulência presentes no pAA2 dependem deste regulador, definindo o regulon AggR (HARRINGTON; DUDLEY; NATARO, 2006). Morin et al. (2012) confirmaram a existência de ao menos 44 genes regulados por AggR utilizando a técnica de microarray e qRT-PCR. Destes genes, 16 codificam proteínas hipotéticas e somente cinco mostram homologia com outras proteínas conhecidas, incluindo os genes da biogênese de AAF/II, Pet, dispersina e uma ilha de patogenicidade cromossômica.

Recentemente foi proposta a classificação de amostras de EAEC nos grupos típica e atípica, levando em conta a presença ou ausência do gene aggR e, consequentemente, de seu regulon (HARRINGTON; DUDLEY; NATARO 2006; 
SARANTUYA et al., 2004). Essa classificação definiria dois grupos de amostras, sendo que o primeiro constituído pelas amostras típicas, com maior potencial patogênico pelo fato de apresentarem os genes de virulência regulados por AggR e o plasmídio de virulência PAA (HARRINGTON; DUDLEY; NATARO, 2006; KAPER; NATARO; MOBLEY, 2004; SARANTUYA et al., 2004).

No estágio inicial de aderência de EAEC participam adesinas fimbrias e afimbriais. Entretanto, apenas as adesinas fimbriais têm sido caracterizadas geneticamente (NAVARRO-GARCIA; ELIAS, 2011). Quatro fímbrias de aderência agregativa (AAF) já foram caracterizadas em EAEC (BERNIER; GOUNON; LE BOUGUÉNEC, 2002; BOISEN et al., 2008; CZECZULIN et al., 1997; NATARO et al., 1992).

A fímbria $A A F / l$ é responsável pelo padrão AA da amostra EAEC 17-2 (NATARO et al., 1992). Os genes responsáveis pela biogênese dessa fímbria estão localizados em duas regiões do plasmídio pAA1, designadas como região 1 (operon aggABCD) e região 2 (regulador transcricional aggR) (NATARO et al., 1992; NATARO et al., 1994; SAVARINO et al., 1994).

A fímbria $A A F / I I$ é responsável pelo fenótipo AA expresso pela amostra EAEC 042 (CZECZULIN et al., 1997). Os genes responsáveis pela biogênese de AAF/II estão localizados no plasmídio pAA2 em duas regiões organizadas de forma peculiar, uma contendo os genes aafA, aafD e agg $R$ (região 1) e a outra o gene aafC (região 2) (ELIAS et al., 1999).

A terceira fímbria, denominada AFF/III foi identificada na amostra de EAEC 55989 (sorotipo O104:H4) e também está envolvida na adesão às células epiteliais no padrão AA (BERNIER; GOUNON; LE BOUGUÉNEC, 2002). Os genes responsáveis pela biogênese dessa fímbria são denominados agg3ABCD e aggR e estão organizados em duas regiões no plasmídio pAA3 similares à organização genética de AAF/I (NAVARRO-GARCIA et al., 2010).

A adesina descrita por Boisen et al. (2008), responsável pelo padrão de adesão AA na amostra $\mathrm{C1010-00} \mathrm{(sorotipo} \mathrm{OR:H1)} \mathrm{isolada} \mathrm{na} \mathrm{Dinamarca,} \mathrm{foi}$ inicialmente denominada $\mathrm{HdA}$. O operon $h d a A B C D$ que codifica a fímbria é aparentemente regulado por aggR e responsável pelo fenótipo agregativo em amostras de EAEC que não apresentam as outras adesinas AAF. Posteriormente, 
essa adesina foi renomeada AAF/IV e seu operon chamado de agg $4 A B C D$ (BOISEN et al., 2012; NAVARRO-GARCIA; ELIAS, 2011).

Foi demonstrado que em uma amostra de EAEC atípica isolada na Sérvia denominada C1096 (sorotipo O4:HNT), a adesão agregativa em células epiteliais cultivadas e à superfície abiótica era mediada por um pili do tipo IV, codificado por genes presentes em um plasmídio do grupo de incompatibilidade Incl1. O gene pilS codifica a pilina correspondente a subunidade principal do pili tipo IV descrito nessa amostra. A expressão do pili tipo IV é necessária, mas não totalmente responsável pela aderência agregativa e formação de biofilme (COBELJIC et al., 1996; DUDLEY et al., 2006a).

A proteína dispersina ou Aap (anti agregation protein) constitui um importante fator de virulência de EAEC, responsável por mediar a dispersão de EAEC na mucosa intestinal (SHEIKH et al., 2002). É codificada pelo gene aap localizado no plasmídio pAA2 (CZECZULIN et al., 1999; SHEIKH et al., 2002). A dispersina é uma proteína secretada para o meio externo onde fica ligada ao lipopolissacarídeo da bactéria, o que neutraliza a carga negativa da superfície da célula bacteriana e permite a projeção das fímbrias AAF, levando a um fenótipo de antiagregação e dispersão da bactéria pela mucosa intestinal (VELARDE et al., 2007).

A dispersina requer um sistema de transporte do tipo $A B C$, codificado pelo operon aatPABCD (enteroaggregative $A B C$ transporter), presente no plasmídio pAA2 (NISHI et al., 2003). O gene aatA corresponde ao fragmento sonda CVD432, desenvolvido por Baudry et al. (1990), e codifica uma proteína de membrana externa que age diretamente como um poro para a translocação da proteína dispersina (NISHI et al., 2003).

O gene shf, também localizado no pAA2, não apresenta função conhecida, mas tem homologia com dois genes descritos em Shigella flexneri 2a (shf1 e shf2) que codificam um proteína similar a IcaB de Staphylococcus epidermidis relacionada com a formação de biofilme (CZECZULIN et al., 1999). Estudos com a amostra protótipo EAEC 042 e mutantes sugerem que o gene shf não tem relação com a agregação na fase líquida e na fase inicial de aderência, mas é necessário para formar múltiplas camadas no biofilme na fase de maturação, exercendo papel crucial 
na capacidade de formação de biofilme (FUJIYAMA et al., 2008; VASCONCELLOS, 2009).

EAEC produz alguns efeitos citotóxicos como vesiculação das microvilosidades e aumento na extrusão das células epiteliais (HARRINGTON; DUDLEY; NATARO, 2006). Várias toxinas têm sido associadas a estes efeitos citotóxicos. Dentre elas Pet e EAST-1, codificadas por genes plasmidiais (ESLAVA et al., 1998; SAVARINO et al., 1993), e Shet1 e Pic, codificadas por genes cromossômicos (HENDERSON et al., 1999).

EAST-1 (enteroaggregative heat-stable toxin 1) é uma enterotoxina termoestável, mas imunologica e geneticamente distinta da toxina termo-estável de ETEC (SAVARINO et al., 1991). É codificada pelo gene astA presente nos plasmídios pAA (CZECZULIN et al., 1999). A toxina ativa adenilato ciclase, induzindo a ação de GMP cíclico que altera o transporte de íons gerando uma resposta secretória (SAVARINO et al., 1991; SAVARINO et al., 1993).

A toxina Pet (plasmid-enconded toxin), pertence à classe de proteínas autotransportadoras (CZECZULIN et al., 1999; NAVARRO-GARCIA et al., 1998). Pet é uma citotoxina que altera o citoesqueleto dos enterócitos levando ao arredondamento e descolamento celular. O mecanismo citotóxico de Pet decorre da degradação da a-fodrina, uma proteína de membrana dos enterócitos (NAVARROGARCIA et al., 1998; VILLASECA et al., 2000).

Pic (protein involved in colonization), também uma proteína autotransportadora, apresenta atividade mucinolítica e de hemaglutinação. Os fenótipos identificados para Pic sugerem que ela esteja envolvida nas fases iniciais da patogênese de EAEC, promovendo a colonização do intestino (HENDERSON, et al., 1999; NAVARRO-GARCIA; ELIAS, 2011).

Recentemente foi identificada uma ilha de patogenicidade (PAI) inserida no locus do tRNA pheU no cromossomo da amostra EAEC 042. Essa PAI pheU apresenta 117 kb e codifica um sistema de secreção do tipo VI codificado pelo operon aai (AggR-activated island) composto por 25 genes (de aaiA até aaiY). (DUDLEY et al., 2006b). No sistema de secreção do tipo VI descrito na amostra protótipo 042 o aparato para a secreção da proteína AaiC é composto pelos genes 
aaiA até aaiP. AaiC foi descrita como sendo uma proteína que não apresenta homólogos no GenBank (DUDLEY et al., 2006b).

A contribuição dos produtos dos genes aai na patogênese de EAEC ainda é desconhecida, porém essas proteínas parecem não ter um papel na aderência da bactéria a superfícies abióticas ou das células epiteliais intestinais, como ocorre com outros genes regulados por AggR (HARRINGTON; DUDLEY; NATARO, 2006).

A distribuição desses e de outros genes de virulência não é homogênea entre as cepas de EAEC, evidenciando a heterogeneidade deste patótipo. Dessa forma é difícil fornecer uma definição genotípica para EAEC ou propor com exatidão todo o modelo de patogênese. Essa heterogeneidade esclarece em parte a falha de alguns estudos em associar essas cepas à diarreia e sugerem que somente um determinado grupo de isolados de EAEC sejam patógenos humanos (ESTRADAGARCIA; NAVARRO-GARCIA, 2012; HARRINGTON; DUDLEY; NATARO, 2006).

O padrão AA, demonstrado no teste de adesão em células HeLa ou HEp-2, é considerado como o diagnóstico padrão para a identificação de EAEC, uma vez que ainda não foi encontrado um determinante genético comum para todas as amostras deste patótipo (ESTRADA-GARCIA; NAVARRO-GARCIA, 2012; NATARO, 2005). Entretanto, a técnica do teste de adesão em células epiteliais cultivadas é dispendiosa, demorada e necessita de infraestrutura restrita a laboratórios de referência. Na tentativa de propor um ensaio com menos limitações, aderência em células HEp-2 fixadas com formalina foi proposta para facilitar a execução do ensaio, porém apesar da boa especificidade e sensibilidade, não tem sido utilizada (MIQDADY et al., 2002).

Como alternativa aos ensaios de adesão, técnicas moleculares de diagnóstico de EAEC começaram a ser desenvolvidas, por serem mais rápidas, práticas e possibilitarem a análise de um maior número de amostras.

Baudry et al. (1990) desenvolveram uma sonda para o diagnóstico de EAEC, denominada CVD432, a qual foi inicialmente descrita como um fragmento críptico do plasmídio pAA1 da amostra EAEC 17-2. Essa sonda tem sido amplamente utilizada em diversos estudos epidemiológicos, demonstrando especificidade e sensibilidade muito variável (FANG et al., 1995; GIOPPO et al., 2000; GOMES et al., 1998; OKEKE et al., 2003). 
Posteriormente, esse fragmento foi sequenciado permitindo a síntese de um par de iniciadores para a detecção de EAEC através de uma reação em cadeia da polimerase (PCR) (SCHMIDT et al., 1995). Recentemente, Nishi et al. (2003) evidenciaram que o fragmento sonda CVD432 corresponde à parte do gene aat $A$ que, conforme mencionado anteriormente, faz parte de um operon de cinco genes $($ aatPABCD) que codificam as proteínas do sistema do tipo $A B C$ de secreção. Desta forma, a sonda CVD432 passou a ser corretamente denominada de aatA.

A reatividade com o fragmento aat $A$, através de ensaios de hibridização de colônias ou PCR, indica a presença do plasmídio pAA, ou seja, detecta apenas amostras de EAEC típicas. Essa técnica exclui a grande maioria das EAEC atípicas, as quais são bastante prevalentes em vários países, conforme apresentado na tabela 1.

Tabela 1 - Estudos epidemiológicos sobre a etiologia da diarreia aguda com pesquisa de EAEC atípica

\begin{tabular}{|c|c|c|c|c|c|}
\hline \multirow[t]{2}{*}{$\begin{array}{l}\text { Local de } \\
\text { isolamento }\end{array}$} & \multirow[t]{2}{*}{$\begin{array}{l}\text { População } \\
\text { estudada }\end{array}$} & \multirow[t]{2}{*}{$\begin{array}{l}\text { Método de } \\
\text { detecção }\end{array}$} & \multicolumn{2}{|c|}{$\begin{array}{l}\text { Reatividade com } \\
\text { aggR }\end{array}$} & \multirow[t]{2}{*}{ Referência } \\
\hline & & & $\begin{array}{l}\% \text { de } \\
\text { amostras } \\
\text { positivas }\end{array}$ & $\begin{array}{l}\% \text { de } \\
\text { amostras } \\
\text { negativas }\end{array}$ & \\
\hline Bamako, Mali & $\begin{array}{l}\text { Crianças até } 5 \\
\text { anos }\end{array}$ & PCR (aaiC e aatA) & 69,4 & 30,6 & $\begin{array}{l}\text { Boisen et al., } \\
2012\end{array}$ \\
\hline $\begin{array}{l}\text { México, Índia } \\
\text { e Guatemala }\end{array}$ & Adultos & AA em células HEp-2 & 30 & 70 & $\begin{array}{l}\text { Huang et al., } \\
2007\end{array}$ \\
\hline Hamadan, Irã & $\begin{array}{l}\text { Crianças até } 12 \\
\text { anos }\end{array}$ & $\begin{array}{l}\text { Sonda CVD } 432 \text { e AA } \\
\text { em células HeLa }\end{array}$ & 73,3 & 26,7 & $\begin{array}{l}\text { Aslani et al., } \\
2010\end{array}$ \\
\hline $\begin{array}{l}\text { São Paulo, } \\
\text { Brasil }\end{array}$ & $\begin{array}{l}\text { Crianças até } 5 \\
\text { anos }\end{array}$ & $\begin{array}{l}\text { Sonda CVD432 e AA } \\
\text { em células HeLa }\end{array}$ & 74,2 & 25,8 & $\begin{array}{l}\text { Elias et al., } \\
2002\end{array}$ \\
\hline México & Adultos & AA em células HEp-2 & 27,5 & 72,5 & $\begin{array}{l}\text { Huang et al., } \\
2003\end{array}$ \\
\hline $\begin{array}{l}\text { Brasil (várias } \\
\text { localidades) }\end{array}$ & $\begin{array}{l}\text { Crianças até } 2 \\
\text { anos }\end{array}$ & AA em células HEp-2 & 71,5 & 28,4 & $\begin{array}{l}\text { Zamboni et al., } \\
2004\end{array}$ \\
\hline $\begin{array}{l}\text { Índia, Jamaica } \\
\text { e México }\end{array}$ & Adultos & AA em células HEp-2 & 41 & 59 & $\begin{array}{l}\text { Jiang et al., } \\
2002\end{array}$ \\
\hline $\begin{array}{l}\text { Espirito Santo, } \\
\text { Brasil }\end{array}$ & $\begin{array}{l}\text { Crianças até } 12 \\
\text { anos }\end{array}$ & $\begin{array}{l}\text { Sonda CVD } 432 \text { e AA } \\
\text { em células HEp-2 }\end{array}$ & 16,4 & 83,6 & $\begin{array}{l}\text { Monfardini, } \\
2012\end{array}$ \\
\hline
\end{tabular}


Há vários relatos na literatura sobre o desenvolvimento de PCR multiplex para a detecção de vários patótipos de DEC simultaneamente. Entretanto, aqueles ensaios que incluem a detecção de EAEC utilizam na sua maioria apenas um ou dois marcadores plasmidiais, não abordando a detecção de EAEC atípica (ARANDA et al., 2007; BUERIS et al., 2007; FUJIOKA et al., 2009; PANCHALINGAM et al., 2012; SOUZA et al., 2013; TOMA et al., 2003).

Alguns autores propuseram o diagnóstico isolado para EAEC baseado na técnica de PCR multiplex, empregando a detecção simultânea de marcadores plasmidiais (BOUZARI; JAFARI; ZAREPOUR, 2005; CERNA; NATARO; GARCIAESTRADA, 2003; RÜTTLER et al., 2006) ou plasmidiais e cromossômicos (JENKINS et al., 2006b).

Cerna, Nataro e Garcia-Estrada (2003) padronizaram uma PCR multiplex para a detecção de três genes plasmidiais de EAEC (aatA, aap e aggR). O método foi eficaz para a detecção de EAEC, porém só foram avaliadas amostras pertencentes a este patótipo, não permitindo os cálculos de especificidade e sensibilidade. $O$ mesmo foi realizado por Bouzari, Jafari e Zarepour (2005), alcançando resultados similares. Essa mesma técnica também foi avaliada como específica e sensível para a caracterização de amostras de EAEC isoladas de fezes diarreicas (CORDEIRO et al., 2008). Por outro lado, Monteiro et al. (2009) avaliou essa técnica incluindo amostras de outros patótipos de DEC e E. coli não patogênicas, demonstrando que o gene que codifica a dispersina (aap) não é exclusivo de EAEC.

Rüttler et al. (2006) padronizaram uma PCR multiplex para detecção simultânea de aggR e astA, que codifica a enterotoxina EAST-1 (SAVARINO et al., 1993). Entretanto, o gene ast $A$ já foi detectado em outros patótipos de DEC e em $E$. coli da microbiota intestinal (SAVARINO et al., 1996) e dessa forma não é específico para EAEC, fato que impossibilita o seu uso como um marcador para este patótipo.

Já a PCR multiplex descrita por Jenkins et al. (2006b) detecta o gene cromossômico aaiA, localizado na PAl aai inserida em pheU, além dos genes plasmidiais aat $A$ e ast $A$. Esses autores demonstraram que os genes aat $A$ e aai $A$ podem ser bons marcadores no diagnóstico de EAEC típicas e atípicas, mas o ensaio descrito detecta também o gene ast $A$, mencionado anteriormente como inespecífico para EAEC. 
Tendo em vista o significado epidemiológico de EAEC atípica e típica em nosso meio, faz-se necessário o estabelecimento de marcadores de virulência específicos para esses dois subgrupos de EAEC, assim como o desenvolvimento de uma técnica diagnóstica rápida em substituição ao teste de adesão em células HeLa/HEp-2, podendo ser uma alternativa futura também para os laboratórios clínicos na identificação de EAEC.

Desse modo, o presente estudo visa caracterizar e padronizar uma PCR multiplex contendo dois genes plasmidias (aat $A$ e agg $R$ ) e dois cromossômicos, afim de detectar EAEC típica e atípica. Para isso foram selecionados quatro genes cromossômicos (aaiA, aaiC, aaiG e aail) pertencentes a PAI pheU da EAEC 042 para a determinação de suas frequências e especificidades, permitindo a escolha de dois deles para a composição da PCR multiplex para EAEC típica e atípica. 


\section{OBJETIVOS}

Padronizar um ensaio de PCR multiplex para o diagnóstico de EAEC típica e atípica e avaliar a sua sensibilidade e especificidade. 


\section{MATERIAL E MÉTODOS}

\subsection{Amostras bacterianas}

Como controles positivos foram empregadas neste estudo as amostras protótipo de EAEC típicas 042 e 17-2 (NATARO et al., 1985; NATARO et al., 1992) e como controle negativo foi utilizada a amostra de E. coli DH5a (SAMBROOK; FRITSCH; MANIATIS, 1989).

Nos ensaios de PCR foram empregadas as seguintes coleções de amostras: - 103 amostras de EAEC isoladas em um estudo epidemiológico sobre a etiologia da doença diarreica na infância na cidade de São Paulo (GOMES et al., 1998). Essas amostras foram classificadas como EAEC através da detecção do padrão AA em células HeLa e caracterizadas quanto à prevalência dos genes de virulência de EAEC (ELIAS et al., 2002; GOMES et al., 1998). Elas fazem parte da coleção de culturas da Profa. Dra. Tânia A. T. Gomes (Disciplina de Microbiologia da Escola Paulista de Medicina - UNIFESP) e foram denominadas EAEC-EPM.

- 97 amostras de E. coli diarreiogênicas compreendendo: 40 EPEC (20 típicas e 20 atípicas), 20 ETEC, 17 EIEC, 20 STEC e 20 DAEC, que fazem parte da coleção de culturas do Laboratório de Bacteriologia do Instituto do Butantan. Essas amostras foram isoladas e caracterizadas em estudos prévios como pertencentes a esses patótipos, devido à presença de fatores de virulência específicos (BUERIS et al., 2007; MAIRENA et al., 2004; MARTINEZ et al., 1999; MENEZES et al., 2006; MONTEIRO et al., 2009; TADDEl et al., 2003). Essa coleção foi denominada DEC$\mathrm{IBu}$.

- 34 amostras de diferentes espécies da família Enterobacteriaceae, com exceção de E. coli (Shigella boydii, Shigella flexneri, Salmonella Agona, S. Infantis, Salmonella Newport, Salmonella enterica sorovar Typhimurium, Citrobacter freundii, Hafnia alvei, Providencia spp., Klebsiella oxytoca, Klebsiella pneumoniae, Proteus mirabilis, Morganella morganii, Enterobacter cloacae, Edwardsiella tarda, Erwinia spp. e Serratia marcescens), que fazem parte da coleção de culturas do Laboratório de Bacteriologia do Instituto do Butantan. Essa coleção foi denominada EnterobacIBu. 
- 42 amostras de E. coli isoladas em um estudo epidemiológico sobre a etiologia da doença diarreica na infância (BUERIS et al., 2007; GOMES et al., 1998). Essas amostras fazem parte da coleção de culturas do Laboratório de Bacteriologia do Instituto do Butantan e da coleção de culturas da Profa. Dra. Tânia A. T. Gomes (Disciplina de Microbiologia da Escola Paulista de Medicina - UNIFSEP). Todas essas amostras são desprovidas de marcadores de virulência de DEC e não apresentam padrão de adesão agregativo ou difuso em células epiteliais cultivadas HEp-2 ou HeLa, desse modo são consideradas como E. coli não patogênicas. Essa coleção foi denominada Microbiota.

\subsection{Cultivo das amostras bacterianas}

Todas as amostras bacterianas foram cultivadas em caldo TSB (tryptic soy broth) a $37^{\circ} \mathrm{C}$ durante $18 \mathrm{~h}$. Após esse período, as culturas positivas foram semeadas em ágar McConkey para análise da pureza da cultura. As placas foram mantidas a $37^{\circ} \mathrm{C}$ durante $18 \mathrm{~h}$ e em seguida uma colônia isolada foi transferida para uma nova placa contendo ágar Luria Bertani (LB) também mantidas a $37^{\circ} \mathrm{C}$ por 18 h. Em seguida, uma colônia isolada foi selecionada para o preparo do lisado, descrito a seguir.

\subsection{Pesquisa dos genes aaiA, aaiC, aaiG e aaiU}

\subsubsection{Reação em Cadeia da Polimerase (PCR)}

A detecção dos genes aaiA, aaiC, aaiG e aail através da técnica de PCR foi realizada nas coleções EAEC-EPM, DEC-IBu, Enterobac-IBu e Microbiota, utilizando como controles positivos as amostras protótipos de EAEC 042 e 17-2 e como controle negativo a amostra DH5a. As reações de PCR foram realizadas em um termociclador GeneAmp PCR System 9700 (Applied Biosystem, EUA).

Os lisados bacterianos utilizados como DNA molde nas reações de amplificação foram obtidos da seguinte forma: uma colônia isolada de uma placa de 
ágar LB foi transferida para um tubo de polipropileno contendo $300 \mu \mathrm{L}$ de água MilliQ estéril, submetida à fervura por 10 min e imediatamente resfriada em banho de gelo.

Para cada reação foram utilizados $1 \mu \mathrm{L}$ do DNA molde, 2,5 U de Taq DNA Polymerase (Invitrogen, EUA), 1,5 mM de cloreto de magnésio, tampão de PCR 1X e 0,2 mM da mistura de dNTPs (Invitrogen). A concentração dos iniciadores foram as seguintes: 40 pmol para aaiA e 25 pmol para aaiC, aaiG, e aaiU, sendo essas concentrações satisfatórias para a amplificação dos respectivos genes. As sequências dos iniciadores e os ciclos de amplificação para cada um deles estão listados na tabela 2. As sequências dos iniciadores para os genes aaiA e aaiC foram obtidos do estudo de Dudley et al. (2006b) e as sequências de aaiG e aaiU foram desenhadas a partir das respectivas sequências da amostra 042 (número de acesso no GeneBank FN554766).

Tabela 2- Sequências dos iniciadores, tamanhos dos fragmentos amplificados e ciclos de amplificação das reações de PCR para os genes aaiA, aaiC, aaiG e aaiU

\begin{tabular}{|c|c|c|c|c|}
\hline Gene & $\begin{array}{c}\text { Sequência dos iniciadores } \\
\left(5^{\prime}-3^{\prime}\right)\end{array}$ & Amplicon & $\begin{array}{c}\text { Ciclo de } \\
\text { amplificação }\end{array}$ & Referência \\
\hline aaiA & $\begin{array}{l}\text { (F) CCCACGACCAGATAACG } \\
\text { (R) } \\
\text { GTTTTCAGGATTGCCATTAG }\end{array}$ & $476 \mathrm{pb}$ & $\begin{array}{l}25 \mathrm{x}: 94^{\circ} \mathrm{C} / 30 \mathrm{~s}, 50 \\
{ }^{\circ} \mathrm{C} / 30 \mathrm{~s}, 72^{\circ} \mathrm{C} / 30 \mathrm{~s} .\end{array}$ & $\begin{array}{l}\text { Dudley et al. } \\
(2006 b)\end{array}$ \\
\hline aaic & $\begin{array}{l}\text { (F) } \\
\text { AAAAAATCTAGATGTCAAAT } \\
\text { AGAGATATAGGTG } \\
\text { (R) } \\
\text { TATATATCTAGAAACAACCT } \\
\text { TAAATGATGAGT }\end{array}$ & $278 \mathrm{pb}$ & $\begin{array}{l}30 \mathrm{x}: 94^{\circ} \mathrm{C} / 1 \mathrm{~m}, 52 \\
{ }^{\circ} \mathrm{C} / 1 \mathrm{~m}, 72^{\circ} \mathrm{C} / 1 \mathrm{~m} .\end{array}$ & $\begin{array}{l}\text { Dudley et al. } \\
(2006 b)\end{array}$ \\
\hline aaiG & $\begin{array}{l}\text { (F) } \\
\text { GGGAGTGTTTCAGTCTGGA } \\
\text { C } \\
\text { (R) } \\
\text { ATTTGTCACAAGCTCAGCAT }\end{array}$ & $782 \mathrm{pb}$ & $\begin{array}{l}30 \mathrm{x}: 94^{\circ} \mathrm{C} / 1 \mathrm{~m}, 55 \\
{ }^{\circ} \mathrm{C} / 1 \mathrm{~m}, 72^{\circ} \mathrm{C} / 1 \mathrm{~m} .\end{array}$ & Este estudo \\
\hline aaiU & $\begin{array}{l}\text { (F) } \\
\text { CAGACAGGAAGCATGGTTC } \\
\text { A } \\
\text { (R) } \\
\text { CAGGCATGTCATACTCAAG } \\
\text { A }\end{array}$ & $806 \mathrm{pb}$ & $\begin{array}{l}30 \mathrm{x}: 94^{\circ} \mathrm{C} / 1 \mathrm{~m}, \\
54^{\circ} \mathrm{C} / 1 \mathrm{~m}, 72^{\circ} \mathrm{C} / 1 \\
\mathrm{~m} .\end{array}$ & Este estudo \\
\hline
\end{tabular}

$(\mathrm{F})$ iniciador forward; $(\mathrm{R})$ iniciador reverse. 


\subsubsection{Eletroforese em gel de agarose}

Os géis de agarose foram preparados por aquecimento, fundindo-se agarose (Invitrogen) em tampão TAE $1 \times$ (Tris base $0,04 \mathrm{M}$, ácido acético glacial $1 \mathrm{M}$, EDTA $50 \mathrm{mM}$ ), nas concentrações de 1 ou $2 \%$. Os fragmentos de DNA obtidos através das reações de PCR foram acrescidos de tampão de amostra 1x (azul de bromofenol 0,25\%; xileno cianol $0,25 \%$; glicerol $30 \%$ ). A eletroforese foi realizada utilizando como tampão de corrida também o TAE $1 \mathrm{x}$ em uma corrente constante de 70 a $80 \mathrm{~V}$. Os marcadores de tamanho molecular $1 \mathrm{~Kb}$ DNA Ladder (Invitrogen) ou $100 \mathrm{bp}$ DNA Ladder (Invitrogen) foram utilizados para verificar o tamanho dos produtos amplificados. As bandas foram detectadas através da coloração por solução de brometo de etídeo na concentração de $10 \mu \mathrm{g} / \mathrm{mL}$ ou com solução de Gel Red ${ }^{T M}$ (Molecular Probes, EUA) na concentração de 1:10000 e visualizadas utilizando um transiluminador de luz ultravioleta, registrando as imagens por um sistema de captação de imagens Alphalmager 2200 (Alpha Innotech, EUA).

\subsubsection{Sequenciamento dos amplicons}

Os produtos amplificados em algumas PCR para a detecção dos genes aaiA, aaiC, aaiG e aaiU, foram sequenciados para confirmação da especificidade dos iniciadores. Os amplicons foram purificados a partir do produto da reação de PCR com auxílio do GFX ${ }^{\mathrm{TM}}$ PCR DNA and Gel Band Purification Kit (GE Healthcare, EUA), de acordo com instruções do fabricante. Após a purificação, os fragmentos foram quantificados a partir de eletroforese em gel de agarose a $2 \%$ utilizando como padrão de concentração de DNA o marcador de massa molecular Low DNA Mass Ladder (Invitrogen). O sequenciamento foi realizado no Centro de Estudos do Genoma Humano (Universidade de São Paulo), utilizando o sequenciador automático MegaBACE 1000 (Amersham Pharmacia Biotech). As reações foram realizadas de acordo com o protocolo do fabricante, utilizando o kit APBiotech DYEnamic ET Dye Terminator Cycle Sequencing (empregando a Thermo Sequenase $^{\mathrm{TM}}$ II DNA Polimerase) e os iniciadores específicos, na concentração de 5 pmol cada. As sequências obtidas foram analisadas e alinhadas com auxílio do 
software BioEdit. As sequências obtidas foram comparadas com as respectivas da amostra 042 no banco de dados do Pubmed através do BLAST (http://blast.ncbi.nlm.nih.gov/), a fim de confirmar a especificidade de todos os iniciadores.

\subsection{PCR multiplex}

Para a padronização da PCR multiplex foram utilizados os genes cromossômicos aaiA e aaiG, escolhidos após a determinação da prevalência dos mesmos nas amostras EAEC-EPM, DEC-IBU, ENTEROBAC-IBU e MICROBIOTA, e os plasmidiais aatA e aggR. Como controles positivos foram utilizadas as amostras 042 e 17-2 e como controles negativos a amostra DH5a. Em um primeiro momento a PCR multiplex foi testada somente com as amostras EAEC-EPM.

As reações de PCR multiplex foram realizadas no termociclador Mastercycler Gradient (Eppendorf) seguindo o protocolo descrito no item 3.3.1, utilizando os iniciadores específicos que estão descritos na tabela 3, assim como as condições da reação de PCR multiplex.

As concentrações dos iniciadores utilizadas na reação foram as seguintes: 20 pmol para aaiA, aaiG e aggR e 50 pmol para aatA. Essas concentrações foram padronizadas através de uma titulação de concentrações de iniciadores de 10 a 100 pmol, variando de 10 pmol em 10 pmol, para cada um deles separadamente. Após a análise dos amplicons em gel de agarose a $1 \%$ foi verificada em qual concentração foi obtido um amplicon de melhor qualidade para cada gene e esta concentração foi a escolhida para a montagem da reação de PCR multiplex. Após a amplificação os produtos obtidos foram analisados em gel de agarose $1 \%$, conforme descrito no item 3.3.2.

Os iniciadores para os genes aaiA e aaiG foram os mesmos empregados no item 3.3. Para aat $A$ foram utilizados iniciadores previamente descritos na literatura (SCHIMIDT et al., 1995).

O iniciador para o gene agg $R$ foi desenhado a partir da respectiva sequência da amostra EAEC 042, obtida no GeneBank (número de acesso: FN554767). O 
produto amplificado a partir da amostra 042 utilizando esses iniciadores foi sequenciado de acordo com o descrito no item 3.3.3.

Tabela 3 - Sequências dos iniciadores, tamanhos dos fragmentos amplificados e ciclo de amplificação da reação de PCR multiplex para os marcadores de virulência de EAEC

\begin{tabular}{|c|c|c|c|c|}
\hline Gene & $\begin{array}{c}\text { Sequência dos iniciadores } \\
\left(5^{\prime}-3^{\prime}\right)\end{array}$ & Amplicon & $\begin{array}{c}\text { Ciclo de } \\
\text { amplificação }\end{array}$ & Referência \\
\hline aaiA & $\begin{array}{l}(\text { F) } \\
\text { CCCACGACCAGATAACG } \\
\text { (R) } \\
\text { GTTTTCAGGATTGCCATTA } \\
\text { G }\end{array}$ & $476 \mathrm{pb}$ & $\begin{array}{l}30 \mathrm{x}: \\
94^{\circ} \mathrm{C} / 1 \mathrm{~min}, \\
56^{\circ} \mathrm{C} / 1 \mathrm{~min},\end{array}$ & Dudley et al. (2006b) \\
\hline aaiG & $\begin{array}{l}\text { (F) } \\
\text { GGGAGTGTTTCAGTCTGG } \\
\text { AC } \\
\text { (R) } \\
\text { ATTTGTCACAAGCTCAGCA } \\
\text { T }\end{array}$ & $782 \mathrm{pb}$ & $72^{\circ} \mathrm{C} / 7 \mathrm{~min}$ & Este estudo \\
\hline $\operatorname{agg} R$ & $\begin{array}{l}\text { (F) } \\
\text { CGATACATTAAGACGCCTA } \\
\text { AAG } \\
\text { (R) } \\
\text { TCTGATACATTAAATTCATC } \\
\text { TGC }\end{array}$ & $346 \mathrm{pb}$ & & Este estudo \\
\hline aatA & $\begin{array}{l}(\text { F) } \\
\text { CTGGCGAAAGACTGTATCA } \\
T \\
\text { (R) } \\
\text { CAATGTATAGAAATCCGCT } \\
\text { GTT }\end{array}$ & $630 \mathrm{pb}$ & & Schimidt et al. (1995) \\
\hline
\end{tabular}

$(\mathrm{F})$ iniciador forward; $(\mathrm{R})$ iniciador reverse.

\subsection{Limite de detecção da PCR multiplex}

Para avaliar o limite de detecção da PCR multiplex foi utilizado o DNA genômico purificado da amostra protótipo 042 em diferentes concentrações. O DNA genômico foi extraído utilizando o kit illustra ${ }^{T M}$ bacteria genomicPrep Mini Spin Kit (GE Healthcare), de acordo com as instruções do fabricante. O produto da extração de DNA foi analisado e quantificado através de eletroforese em gel de agarose a $2 \%$ usando como marcador de peso molecular o High DNA Mass Ladder (Invitrogen). Para confirmação dessa concentração foi realizada a análise no espectrofotômetro 
Ultrospec 2100pro (Amersham Biosciences, Reino Unido) através da leitura de absorbância em comprimento de onda de $260 \mathrm{~nm}$.

Para determinar o limite de detecção da PCR multiplex (descrita no item 3.4) foi empregado como molde o DNA genômico purificado da amostra 042 e seguido o protocolo de padronização da reação. As seguintes concentrações de DNA foram utilizadas: $1,00 \mu \mathrm{g}, 0,75 \mu \mathrm{g}, 0,50 \mu \mathrm{g}, 0,25 \mu \mathrm{g}, 0,125 \mu \mathrm{g}, 0,100 \mu \mathrm{g}, 0,075 \mu \mathrm{g}, 0,050$ $\mu \mathrm{g}, 0,025 \mu \mathrm{g}, 0,0125 \mu \mathrm{g}$ e $0,0100 \mu \mathrm{g}$, diluindo com a quantidade necessária de $\mathrm{H}_{2} \mathrm{O}$ MilliQ estéril para cada uma das concentrações. Após a amplificação, os produtos foram analisados em eletroforese em gel de agarose conforme descrito no item 3.3.2.

\subsection{Validação da PCR multiplex}

Para a validação do ensaio de PCR multiplex foram analisadas 403 amostras de E. coli isoladas em um estudo epidemiológico sobre a etiologia da doença diarreica aguda na infância, conduzido na cidade de São Paulo (SOBEL et al., 2004). As amostras de E. coli foram previamente avaliadas quanto à presença de marcadores de virulência que definem os patótipos de DEC (EPEC, ETEC, EIEC e STEC). Dentro da população estudada, as amostras de 200 casos e 200 controles pareados, selecionados aleatoriamente, tiveram os seus padrões de adesão determinados em ensaios com células HeLa, classificando assim as EAEC e DAEC (GOMES et al., 1998). As EAEC foram posteriormente analisadas quanto à presença do gene aggR, definindo os subgrupos típica e atípica (ELIAS et al., 2002).

Dessa forma, a coleção de E. coli avaliada pela PCR multiplex incluiu amostras de casos e controles classificadas como EPEC (típica e atípica), ETEC, EHEC, EIEC, DAEC, EAEC (típica e atípica), ou como desprovidas de marcadores de virulência que definem $E$. coli diarreiogênicas (amostras não patogênicas). $O$ ensaio desenvolvido no presente estudo foi então aplicado às cegas nessa coleção, ou seja, sem o conhecimento da classificação prévia das amostras para os cálculos de sensibilidade e especificidade.

Dessa forma, o total de 403 amostras selecionadas (198 de casos e 205 de controles) compreenderam 32 amostras de EPEC (14 típicas e 18 atípicas), 17 de 
ETEC, 16 de EIEC, 81 DAEC, 58 EAEC (39 típicas e 19 atípicas) e 199 amostras sem marcadores de virulência de DEC e não aderente em células epiteliais.

Os resultados da PCR multiplex foram confrontados com os dados individuais de cada amostra com relação à classificação ou não em patótipos de DEC. Os cálculos de especificidade, sensibilidade e de valor preditivo (de um teste positivo ou negativo) foram realizados segundo as seguintes fórmulas descritas por Crowther (2001):

Sensibilidade $=$ VP $/($ VP+FN $) \times 100$

Especificidade $=\mathrm{VN} /(\mathrm{VN}+\mathrm{FP}) \times 100$

Valor preditivo do teste positivo $=[\mathrm{VP} /(\mathrm{VP}+\mathrm{FP})] \times 100$

Valor preditivo do teste negativo $=[\mathrm{VN} /(\mathrm{VN}+\mathrm{FN})] \times 100$

Onde:

VP: verdadeiros positivos VN: verdadeiros negativos

FN: falsos negativos FP: falsos positivos

As amostras de EAEC caracterizadas a partir da expressão do padrão AA em células HeLa foram consideradas como "verdadeiros positivos" quando detectadas no ensaio, ou seja, a expressão do padrão AA foi considerada como o padrão ouro para o diagnóstico de EAEC. 


\section{RESULTADOS}

\subsection{Frequência dos genes aaiA, aaiC, aaiG e aaiU}

Os genes aaiA, aaiC e aaiG, cujos produtos compõem um sistema de secreção do tipo $\mathrm{VI}$, e aaiU que codifica uma proteína hipotética, fazem parte de uma PAI inserida em pheU no cromossomo da amostra EAEC 042. Devido a sua localização, os genes dessa PAI têm potencial como bons marcadores para EAEC com ou sem o plasmídio pAA, ou seja, tanto para EAEC típica como atípica. Esses quatro genes foram escolhidos na intenção de selecionar dois deles para a montagem da PCR multiplex, juntamente com os genes aggR e aatA, (plasmidiais) determinados em outros estudos como específicos para EAEC típica.

Inicialmente, as PCR foram padronizadas empregando como controle positivo o DNA da amostra protótipo de EAEC 042. Conforme apresentado na figura 2, houve amplificação de um único fragmento no tamanho esperado em cada uma das reações, ou seja, 476 pb para aaiA, 308 pb para aaiC, 782 pb para aaiG e 806 pb para aaiU.
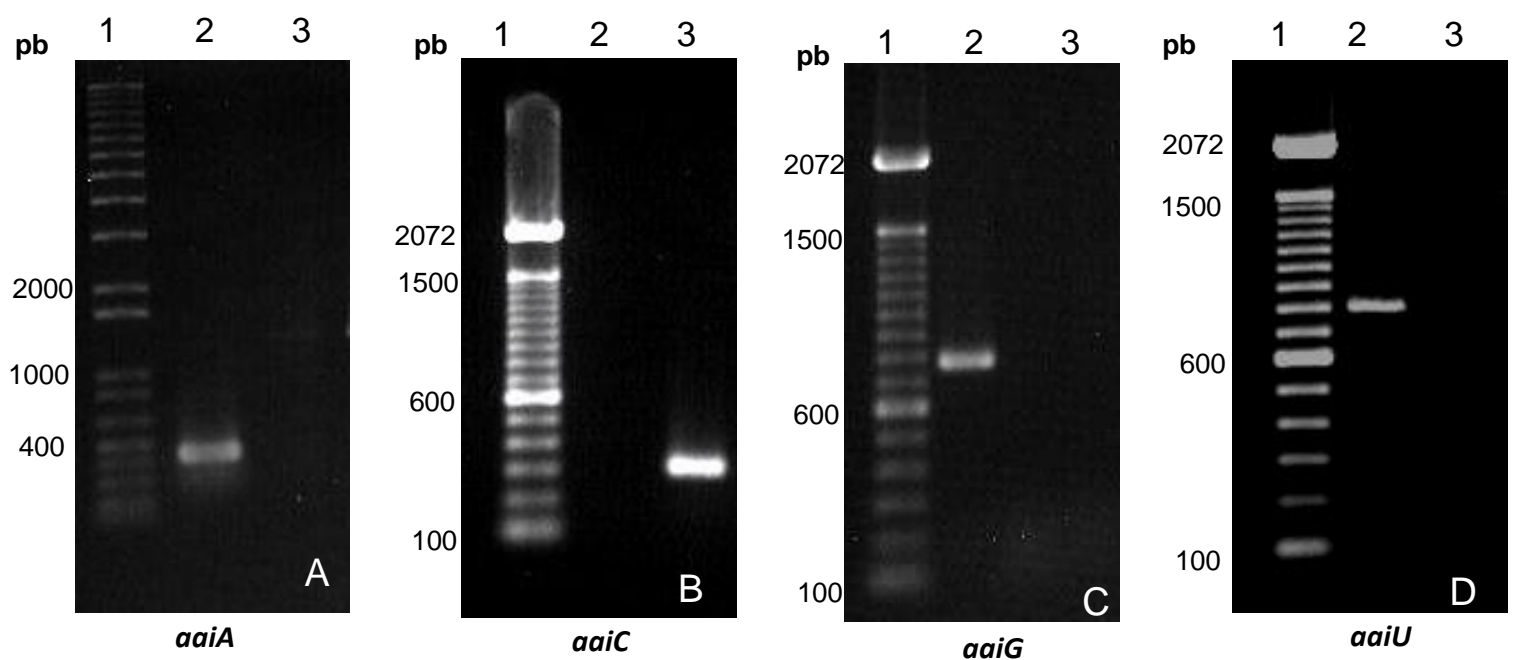

Figura 2 - Eletroforese em gel de agarose (1\%) dos produtos da PCR para detecção de aaiA, aaiC, aaiG e aaiU. (A) Amplificação do gene aaiA. Canaletas: $1-1 \mathrm{~Kb}$ Plus DNA Ladder (Invitrogen); 2 - amostra 042 (controle positivo); 3 - amostra DH5a (controle negativo). (B) Amplificação do gene aaiC. Canaletas: 1 - 100 bp DNA Ladder (Invitrogen); 2 - amostra DH5a; 3 - amostra 042. (C) Amplificação do gene aaiG. Canaletas: 1 - 100 bp DNA Ladder (Invitrogen); 2 - amostra 042; 3 - amostra DH5a. (D) Amplificação do gene aaiU. Canaletas: 1 - 100 bp DNA Ladder (Invitrogen); 2 - amostra 042; 3 - amostra DH5a. 
Após a validação da detecção dos quatro genes através da PCR foi iniciada a etapa de pesquisa da frequência desses genes em outros patótipos de DEC, outras enterobactérias e em amostras de $E$. coli da microbiota. Nessa avaliação pretendiase determinar a especificidade desses genes para EAEC.

Os resultados obtidos a partir das amostras DEC-IBu, Enterobac-IBu e Microbiota mostraram que os genes aaiA, aaiC, aaiG e aaiU apresentam pouca ou nenhuma frequência nessas amostras. A tabela 4 apresenta os resultados obtidos para cada um dos genes, em cada uma das categorias de DEC separadamente, assim como, nas amostras de Enterobac-IBu e Microbiota.

Tabela 4 - Frequência dos genes aaiA, aaiC, aaiG, e aaiU em amostras de E. coli diarreiogênicas, E. coli da microbiota intestinal e outras enterobactérias

\begin{tabular}{|c|c|c|c|c|c|c|c|c|}
\hline \multirow[b]{2}{*}{ Gene } & \multicolumn{8}{|c|}{$\mathbf{N}^{\circ}(\%)$ de amostras positivas } \\
\hline & $\begin{array}{l}\text { EIEC } \\
(n=17)\end{array}$ & $\begin{array}{l}\text { ETEC } \\
(n=20)\end{array}$ & $\begin{array}{l}\text { aEPEC } \\
(n=20)\end{array}$ & $\begin{array}{l}\text { tEPEC } \\
(n=20)\end{array}$ & $\begin{array}{l}\text { DAEC } \\
(\mathrm{n}=20)\end{array}$ & $\begin{array}{l}\text { STEC } \\
(n=20)\end{array}$ & $\begin{array}{c}\text { EB } \\
(n=34)\end{array}$ & $\begin{array}{c}M I \\
(n=42)\end{array}$ \\
\hline aaiA & 0 & 0 & 0 & 0 & 0 & 0 & 0 & $1(2,4)$ \\
\hline aaic & 0 & $1(5)$ & $1(5)$ & 0 & 0 & 0 & 0 & 0 \\
\hline aaiG & 0 & 0 & $2(10)$ & 0 & 0 & 0 & 0 & 0 \\
\hline aail & 0 & 0 & 0 & 0 & 0 & 0 & 0 & 0 \\
\hline
\end{tabular}

EIEC, E. coli enteroinvasora; ETEC, E. coli enterotoxigênica; aEPEC, $E$ coli enteropatogênica atípica; tEPEC, E. coli enteropatogênica típica; DAEC, E. coli de adesão difusa; STEC, E. coli produtora da toxina de Shiga; EB, Enterobactérias; MI, E. coli da microbiota intestinal.

No total de amostras em conjunto a frequência dos quatro genes foi de $2,1 \%$. As quatro amostras em que algum dos genes pesquisados foi detectado estão listadas a seguir, com uma breve descrição de algumas de suas características.

O gene aaiA foi detectado em uma $E$. coli da microbiota intestinal (amostra BA253) a qual apresenta o padrão de adesão indefinido em células HeLa (ensaio de 6h) e não apresenta nenhum dos marcadores de virulência de DEC.

O gene aaiC foi detectado em uma ETEC (amostra 616, sorotipo O25:H16), a qual produz toxina ST; e em uma EPEC atípica (amostra BA1652, sorotipo 0131:H4), que apresenta o padrão de adesão localizado like (LAL) em células HEp2. 
O gene aaiG foi detectado em duas EPEC atípicas: amostra BA1652 (também positiva para aaiC) e amostra BA2145 (sorotipo 0105:H7), a qual apresenta o padrão de adesão agregativo em células HEp-2.

Para confirmar a especificidade dos amplicons obtidos na PCR para os quatro genes, os respectivos produtos de amplificação da amostra 042 foram sequenciados, assim como os amplicons das amostras BA253 (aaiA), ETEC 616 (aaiC), BA1652 (aaiC e aaiG) e BA2145 (aaiG).

As sequências obtidas foram analisadas e comparadas com o banco de dados BLAST (http://blast.ncbi.nlm.nih.gov/). Todas elas apresentaram identidade com os respectivos genes do genoma da EAEC 042 (CHAUDRHURI et al., 2010). Os resultados dessas análises estão apresentados a seguir.

Com relação aos amplicons obtidos a partir da amostra EAEC 042 todas as sequências apresentaram alta identidade com as regiões estudadas dos respectivos genes da mesma amostra, ou seja, 100\% para aaiA e aaiC, 99\% para aaiU e $100 \%$ para aaiG (Figura 3).

A sequência de nucleotídeos do amplicon aaiA da amostra BA253 (Microbiota), apresentou $100 \%$ de identidade com a região de análise do respectivo gene da amostra EAEC 042.

Com relação aos amplicons da amostra BA1652 (EPEC atípica), a sequência de aaiC apresentou $100 \%$ de identidade com a região analisada do respectivo gene da amostra EAEC 042; e a sequência de aaiG apresentou $98 \%$ de identidade com a região de análise, também da amostra EAEC 042.

Já a sequência de nucleotídeos do amplicon aaiC da amostra ETEC 616 apresentou $94 \%$ de identidade com a região de análise do respectivo gene da amostra EAEC 042.

Finalmente, a sequência de nucleotídeos do amplicon aaiG da amostra BA2145 (aEPEC) apresentou 100\% de identidade com a região de análise do respectivo gene da amostra EAEC 042.

Todas as sequências dos amplicons obtidos a partir do DNA da amostra EAEC 042 foram alinhadas com as sequências dos respectivos genes do genoma da amostra EAEC 042 depositadas no GeneBank, utilizando o programa BioEdit. A figura $3(A-D)$ apresenta esses alinhamentos 


\section{(A)}

(b)

gi|28. (b) 042 aaiA

emb| FN554766.1|

.$|\ldots| \ldots|\ldots| \ldots|\ldots| \ldots|\ldots| \ldots|\ldots| \ldots|\ldots| \ldots|\ldots| \ldots$ CAGATAACGTATGATGTTGAAACCGGAGATGCTGAAACTGCGAAAGAGTT CAGATAACGTATGATGTTGAAACCGGAGATGCTGAAACTGCGAAAGAGTT

$$
4893180 \quad 4893190 \quad 4893200 \quad 4893210 \quad 4893220
$$
.$|\ldots| \ldots|\ldots| \ldots|\ldots| \ldots|\ldots| \ldots|\ldots| \ldots|\ldots| \ldots$ gi|284919779|emb|FN554766.1| E ACCCCTTGTCATCGGGGTTTTGGGTGAGTACTCTTCGTCAGAAAAACCAT 042 aaiA ACCCCTTGTCATCGGGGTTTTGGGTGAGTACTCTTCGTCAGAAAAACCAT

gi|284919779|emb|FN554766.1| E 042 aaiA

gi|284919779|emb|FN554766.1| E 042 aaiA

gi |284919779|emb|FN554766.1| E 042 aaiA

gi|284919779|emb|FN554766.1| E 042 aaiA

gi|284919779|emb|FN554766.1| E 042 aaiA
$4893230 \quad 4893240 \quad 4893250 \quad 4893260 \quad 4893270$

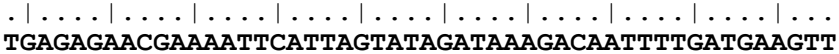
TGAGAGAACGAAAATTCATTAGTATAGATAAAGACAATTTTGATGAAGTT $\begin{array}{lllll}4893280 & 4893290 & 4893300 & 4893310 & 4893320\end{array}$ ATGGCATCAATGAGTCCGACTGCTCATTTTATGGTGGACAGTGTTATCCC ATGGCATCAATGAGTCCGACTGCTCATTTTATGGTGGACAGTGTTATCCC

$4893330 \quad 4893340 \quad 4893350 \quad 4893360 \quad 4893370$ . ... GGGAAATGAAGGAAAACTGGATGTCGAACTGAGGTTTAGTTGCAAAGATG GGGAAATGAAGGAAAACTGGATGTCGAACTGAGGTTTAGTTGCAAAGATG

$4893380 \quad 4893390 \quad 4893400 \quad 4893410 \quad 4893420$ $|\ldots| \ldots|\ldots| \ldots|\ldots| \ldots|\ldots| \ldots|\ldots| \ldots \mid \ldots$ ATTTTTCTCCCGATAATGGATTCAACAGGTTGAGTGTCTAAGAAAATTA ATTTTTCTCCCGATAATGTGATTCAACAGGTTGAGTGTCTAAGAAAATTA

$4893430 \quad 4893440 \quad 4893450 \quad 4893460 \quad 4893470$ $.|\ldots| \ldots|\ldots| \ldots|\ldots| \ldots|\ldots| \ldots|\ldots| \ldots|\ldots| \ldots \mid \ldots$ TCGGAATTGAGGTTGCATCTTTGTGACCTACGAAACAGGGCTGCAAGTAA TCGGAATTGAGGTTGCATCTTTGTGACCTACGAAACAGGGCTGCAAGTAA

$4893480 \quad 4893490 \quad 4893500 \quad 4893510 \quad 4893520$ $.|\ldots| \ldots|\ldots| \ldots|\ldots| \ldots|\ldots| \ldots|\ldots| \ldots|\ldots| \ldots \mid \ldots$ gi|284919779|emb|FN554766.1| E TGAGAAACTGAAAGAAAAACTTCAGGAATTGCTGGTGACTACTAATGGCA 042 aaiA TGAGAAACTGAAAGAAAAACTTCAGGAATTGCTGGTGACTACTAATGGCA

4893530

. | ... . . . .

gi|284919779|emb|FN554766.1| E ATCCTGAAAAC

042 aaiA 
(B)

$4893540 \quad 4893550 \quad 4893560 \quad 4893570 \quad 4893580$ gil: (b) $9 / \mathrm{emb} \mid$ FN554766.1| E AACAGTGGTGACTACTTTGATGGACATTGTCCTCAGGCATTTCACGCTTT 042 dall AACAGTGGTGACTACTTTGATGGACATTGTCCTCAGGCATTTCACGCTTT

$4893590 \quad 4893600 \quad 4893610 \quad 4893620 \quad 4893630$ $\ldots|\ldots| \ldots|\ldots| \ldots|\ldots| \ldots|\ldots| \ldots|\ldots| \ldots|\ldots|$. gi|284919779|emb|FN554766.1| E TTCAGGAATTGACGGTACTGTTTTTGATTTAATTAATTTGAAGCTTAGGG 042 aaic TTCAGGAATTGACGGTACTGTTTTTGATTTAATTAATTTGAAGCTTAGGG

$4893640 \quad 4893650 \quad 4893660 \quad 4893670 \quad 4893680$

$\ldots|\ldots| \ldots|\ldots| \ldots|\ldots| \ldots|\ldots| \ldots|\ldots| \ldots|\ldots|$. gi|284919779|emb| FN554766.1| E TTACTAAACACATACAAGACCTTCTGGAGAACTTTTTTAAGAGAGGTGAA 042 aaic TTACTAAACACATACAAGACCTTCTGGAGAACTTTTTTAAGAGAGGTGAA

$4893690 \quad 4893700 \quad 4893710 \quad 4893720 \quad 4893730$

$\ldots|\ldots| \ldots|\ldots| \ldots|\ldots| \ldots|\ldots| \ldots|\ldots| \ldots|\ldots|$. gi|284919779|emb|FN554766.1| E AAAGAAGTTAAAATAGAAATTTTACGTAGGGAATCAACTAAATCAGGTAG 042 aaic AAAGAAGTTAAAATAGAAATTTTACGTAGGGAATCAACTAAATCAGGTAG

gi|284919779|emb|FN554766.1| E $4893740 \quad 4893750 \quad 4893760$ 042 aaic

$\ldots|\ldots| \ldots|\ldots| \ldots|\ldots|$.

TGCATACTCATCATTTAAGGTTGTTT

TGCATACTCATCATTTAAGGTTGTTT

(C)

gij (b)

$\begin{array}{lllll}4899710 & 4899720 & 4899730 & 4899740 & 4899750\end{array}$ 042 aaig

779 |emb|FN554766.1| E ACAATGACAATGAACATGCTGGTTTGTGTTATTGTGATTTGTGTGCTTCA ACAATGACAATGAACATGCTGGTTTGTGTTATTGTGATTTGTGTGCTTCA

gi|284919779|emb|FN554766.1| E $\begin{array}{lllll}4899760 & 4899770 & 4899780 & 4899790 \quad 4899800\end{array}$ $\ldots|\ldots| \ldots|\ldots| \ldots|\ldots| \ldots|\ldots| \ldots|\ldots| \ldots|\ldots| \ldots$ 042 aaig gatAaTAAAAGCTCACTTAATTTCAGCCGTGAATTTAAAACACCTATTAT

$\begin{array}{rrrrr}4899810 & 4899820 \quad 4899830 \quad 4899840 \quad 4899850\end{array}$ $\ldots|\ldots| \ldots|\ldots| \ldots|\ldots| \ldots|\ldots| \ldots|\ldots| \ldots|\ldots| \ldots \mid$. . . . gi|284919779|emb|FN554766.1| E TCCCGGTGTTTTACTTGCCAGAGTGGTCGGTCCTGACTCCGAAGAATATT 042 aaig TCCCGGTGTTTTACTTGCCAGAGTGGTCGGTCCTGACTCCGAAGAATATT

$4899860 \quad 4899870 \quad 4899880 \quad 4899890 \quad 4899900$ $\ldots|\ldots| \ldots|\ldots| \ldots|\ldots| \ldots|\ldots| \ldots|\ldots| \ldots|\ldots| \ldots$ gi|284919779|emb|FN554766.1| E ATACAGATGATAATGGGCGTGTAAAAATCAGCTTTCTCTGGGGAGAAAG 042 aaig ATACAGATGATAATGGGCGTGTAAAAATCAGCTTTCTCTGGGGAGAAAAG

$4899910 \quad 4899920 \quad 4899930 \quad 4899940 \quad 4899950$ $\ldots|\ldots| \ldots|\ldots| \ldots|\ldots| \ldots|\ldots| \ldots|\ldots| \ldots|\ldots| \ldots$ gi|284919779|emb|FN554766.1| E TCAGCGGCAGGTACAGATAAAACCTCCTGTTGGGTCCGTGTATCTCAGGT 042 aaiG TCAGCGGCAGGTACAGATAAAACCTCCTGTTGGGTCCGTGTATCTCAGGT

$4899960 \quad 4899970 \quad 4899980 \quad 4899990 \quad 4900000$ $\ldots|\ldots| \ldots|\ldots| \ldots|\ldots| \ldots|\ldots| \ldots|\ldots| \ldots|\ldots| \ldots$ gi|284919779|emb|FN554766.1| E ATGGTCCGGGGAGGGATTCGGTAGTCAGTTTATTCCTCGCATTGGCAGTG 042 aaiG ATGGTCCGGGGAGGGATTCGGTAGTCAGTTTATTCCTCGCATTGGCAGTG

$4900010 \quad 4900020 \quad 4900030 \quad 4900040 \quad 4900050$ $\ldots|\ldots| \ldots|\ldots| \ldots|\ldots| \ldots|\ldots| \ldots|\ldots| \ldots \mid \ldots$ gi|284919779| emb| FN554766.1| E AGGTTCTGGTTAGTTTTATACAGGGTAATCCTGACTATCCAGTTATCGTT 042 aaig AGGTTCTGGTTAGTTTTATACAGGGTAATCCTGACTATCCAGTTATCGTT

$4900060 \quad 4900070 \quad 4900080 \quad 4900090 \quad 4900100$ $\ldots|\ldots| \ldots|\ldots| \ldots|\ldots| \ldots|\ldots| \ldots|\ldots| \ldots|\ldots| \ldots$ gi|284919779|emb|FN554766.1| E GGTACAGTGTATAATGGTCAGAATACATCGCCTTTTTCTCTTCCTGAGAA 042 aaig GGTACAGTGTATAATGGTCAGAATACATCGCCTTTTTCTCTTCCTGAGAA

$$
4900110 \quad 4900120 \quad 4900130 \quad 4900140 \quad 4900150
$$

$\ldots|\ldots| \ldots|\ldots| \ldots|\ldots| \ldots|\ldots| \ldots|\ldots| \ldots \mid \ldots$ gi|284919779|emb|FN554766.1| E TAATTGTAAGTCTGGATTTATCACCCGTAGTGTTAAGAATGGTAAAAAAG 
042 aaig

gi|284919779 |emb|FN554766.1| E 042 aaiG

gi|284919779|emb|FN554766.1| E 042 aaig

gi|284919779|emb|FN554766.1| E 042 aaig

gi|284919779|emb|FN554766.1| E 042 aaig

gi|284919779|emb|FN554766.1| E 042 aaig

(D)

(b)

gi|284919779|emb|FN554766.1| E 042 aaiU

gi|284919779|emb|FN554766.1| E 042 aaiu

gi|284919779|emb|FN554766.1| E 042 aaiu

gi|284919779|emb|FN554766.1| E 042 aaiu

gi|284919779|emb|FN554766.1| E 042 aaiu

gi|284919779|emb|FN554766.1| E 042 aaiu

gi|284919779|emb|FN554766.1| E 042 aaiu

$4915950 \quad 4915960 \quad 4915970 \quad 4915980 \quad 4915990$ $\ldots|\ldots| \ldots|\ldots| \ldots|\ldots| \ldots|\ldots| \ldots|\ldots| \ldots|\ldots| \ldots$ CTCATGTTACGGCCACTCAGATGCGGACGAATATTCTTATCTGGTATATT CTCATGTTACGGCCACTCAGATGCGGACGAATATTCTTATCTGGTATATT

$4916000 \quad 4916010 \quad 4916020 \quad 4916030 \quad 4916040$ $\ldots|\ldots| \ldots|\ldots| \ldots|\ldots| \ldots|\ldots| \ldots|\ldots| \ldots$ AAAAATGTTATTCCTGCTATGCAAAGTCTGCCTGATGATGAGAAAACCTA AAAAATGTTATTCCTGCTATGCAAAGTCTGCCTGATGATGAGAAAACCTA

$4916050 \quad 4916060 \quad 4916070 \quad 4916080 \quad 4916090$ $\ldots|\ldots| \ldots|\ldots| \ldots|\ldots| \ldots|\ldots| \ldots|\ldots| \ldots$ CTCGTCATTAACCTTGCTGGAGGATGCATTAACATTATTGGCTGATCTCG CTCGTCATTAACCTTGCTGGAGGATGCATTAACATTATTGGCTGATCTCG

$4916100 \quad 4916110 \quad 4916120 \quad 4916130 \quad 4916140$ $\ldots|\ldots| \ldots|\ldots| \ldots|\ldots| \ldots|\ldots| \ldots|\ldots| \ldots \mid \ldots$ AATACAATCTTCTTTCTGGCAAATTTTTTATCGTTTCAGATATGCTGGCT AATACAATCTTCTTTCTGGCAAATTTTTTATCGTTTCAGATATGCTGGCT

$4916150 \quad 4916160 \quad 4916170 \quad 4916180 \quad 4916190$ $\ldots|\ldots| \ldots|\ldots| \ldots|\ldots| \ldots|\ldots| \ldots|\ldots| \ldots|\ldots| \ldots$ GAACTCAAGAGACAAAAGAGTGATGACTCAGAAAGTACTGATGCCGCACA GAACTCAAGAGACAAAAGAGTGATGACTCAGAAAGTACTGATGCCGCACA

$4916200 \quad 4916210 \quad 4916220 \quad 4916230 \quad 4916240$

$\ldots|\ldots| \ldots|\ldots| \ldots|\ldots| \ldots|\ldots| \ldots|\ldots| \ldots|\ldots| \ldots \mid \ldots$ TCATGATTCAGGATCACATGATGCGAAAGATATTCGGTCTTTTAGCAGTG TCATGATTCAGGATCACATGATGCGAAAGATATTCGGTCTTTTAGCAGTG

$4916250 \quad 4916260 \quad 4916270 \quad 4916280 \quad 4916290$

$\ldots|\ldots| \ldots|\ldots| \ldots|\ldots| \ldots|\ldots| \ldots|\ldots| \ldots|\ldots| \ldots|\ldots| \ldots|\ldots| \ldots \mid$ GTTTACCTACGAATATTGACTCCAATTATACTGCTGGACCAGAACACAAT

$4916300 \quad 4916310 \quad 4916320 \quad 4916330 \quad 4916340$

$\ldots|\ldots| \ldots|\ldots| \ldots|\ldots| \ldots|\ldots| \ldots|\ldots| \ldots|\ldots| \ldots$ gi|284919779|emb|FN554766.1| E ACGTTAATTAAGAAAGATAAGAAACTGCGCATATATTATAACGTCGTTTC 042 aaiu

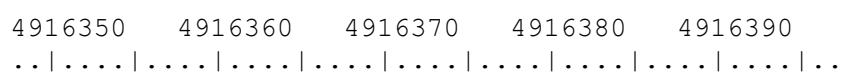




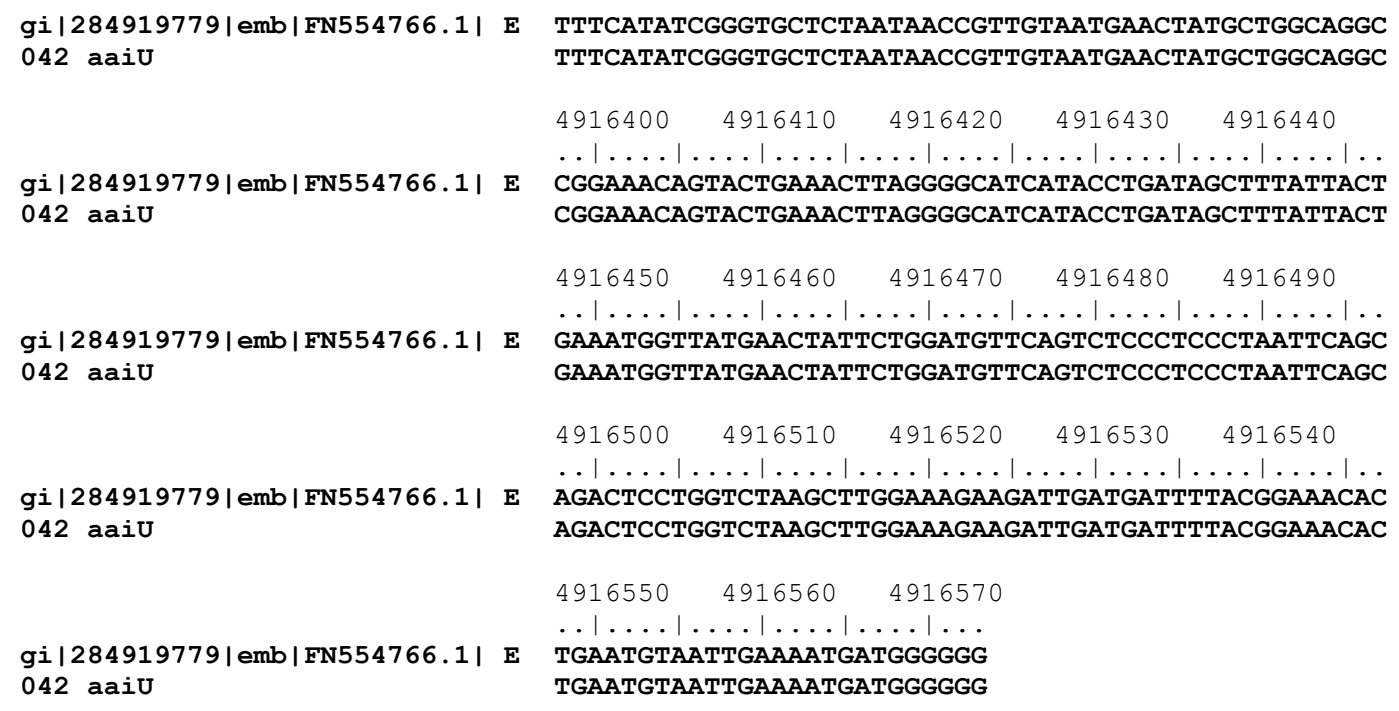

Figura 3 - Alinhamento das sequências de nucleotídeos parciais dos genes aaiA, aaiC, aaiG e aaiU. As sequências foram amplificadas a partir do DNA da amostra protótipo EAEC 042. (A) alinhamento da sequência de nucleotídeo do amplicon aaiA com a sequência disponível no BLAST da amostra 042 (FN554766); (B) alinhamento da sequência de nucleotídeos do amplicon aaiC com a sequência disponível no BLAST da amostra 042 (FN554766); (C) alinhamento da sequência de nucleotídeos do amplicon aaiG com a sequência disponível no BLAST da amostra 042 (FN554766); (D) alinhamento da sequência de nucleotídeos do amplicon aaiU com a sequência disponível no BLAST da amostra 042 (FN554766).

Uma vez determinada a especificidade de todos os produtos amplificados pela PCR, a etapa seguinte deste estudo correspondeu à avaliação da frequência dos quatro genes dessa PAI em amostras de EAEC típicas e atípicas. Para isso foi empregada a coleção de amostras denominada EAEC-EPM.

Os resultados obtidos mostraram que os quatro genes apresentam uma frequência significativa em amostras de EAEC, principalmente nas amostras típicas, sendo que os genes aaiA e aaiG apresentaram os melhores resultados em ambos os grupos. No total de 103 amostras foi observada a frequência de 45,6\% para o gene aai $A, 42,7 \%$ para o gene aaiG, $38,8 \%$ para o gene aaiC e $19,4 \%$ para o gene aaiU. Ao analisar essas frequências nos grupos típica e atípica separadamente, aai $A$ e aaiG também foram os genes mais frequentes e todos os valores foram inferiores no grupo das EAEC atípicas (Figura 4). 


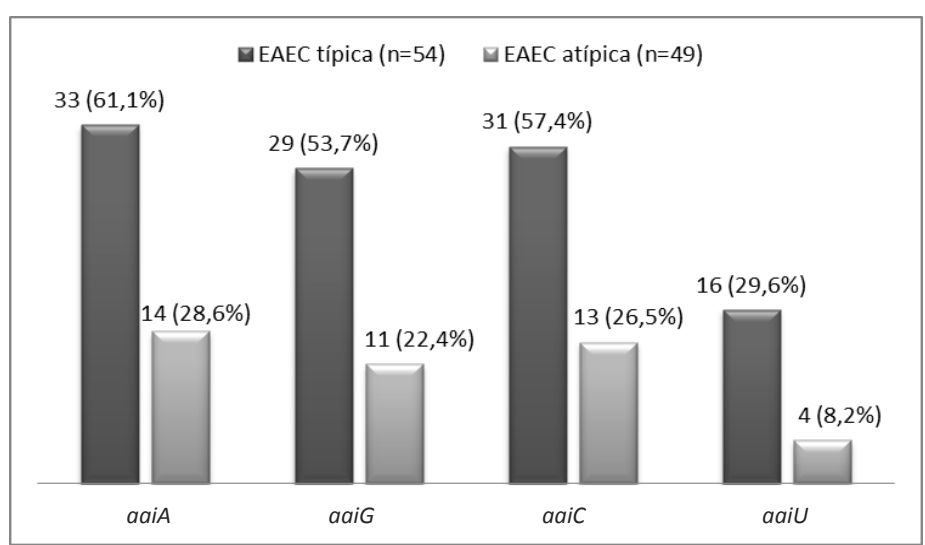

Figura 4 - Frequência dos genes cromossômicos. O gráfico demonstra a frequência dos genes aaiA, aaiC, aaiG, e aaiU em amostras de EAEC típica e atípica.

Em seguida, esses mesmos resultados foram analisados quanto às possíveis combinações dos quatro genes presentes em cada amostra. Conforme apresentado na tabela 5, houve uma grande diversidade de perfis genéticos em ambos os grupos e somente 10 amostras (9 típicas e 1 atípica) apresentaram os quatro genes pesquisados.

Tabela 5 - Perfis genéticos das amostras de EAEC típicas e atípicas com relação aos genes aai $A$, aaiC, aaiG e aail

\begin{tabular}{lcc}
\hline \multirow{2}{*}{ Combinações genéticas } & \multicolumn{2}{c}{$\mathbf{N}^{\circ}(\%)$ de amostras positivas } \\
\cline { 2 - 3 } & $(\mathbf{n}=54)$ & $\begin{array}{c}\text { EAEC atípica } \\
(\mathbf{n}=49)\end{array}$ \\
\hline aaiA & 0 & $1(2)$ \\
aaiC & $4(7,4)$ & $5(10,2)$ \\
aaiG & 0 & 0 \\
aaiU & 0 & $1(2)$ \\
aaiA-aaiC & 0 & $1(2)$ \\
aaiA-aaiG & $1(1,8)$ & $1(2)$ \\
aaiA-aaiU & 0 & 0 \\
aaiC-aaiG & 0 & $1(2)$ \\
aaiC-aaiU & $1(1,8)$ & 0 \\
aaiG-aaiU & 0 & $1(2)$ \\
aaiA-aaiC-aaiG & $14(25,9)$ & $4(8,2)$ \\
aaiA-aaiC-aaiU & $2(3,7)$ & 0 \\
aaiA-aaiG-aaiU & $4(7,4)$ & $2(4,1)$ \\
aaiC-aaiG-aaiU & 0 & 0 \\
aaiA-aaiC-aaiG-aaiU & $9(16,7)$ & $1(2)$ \\
Nenhum dos 4 genes & $21(38,9)$ & $28(57,1)$ \\
\hline
\end{tabular}


Com o objetivo de determinar a porcentagem de detecção de EAEC quando apenas dois desses quatro genes fossem unidos na PCR multiplex, as amostras positivas para cada uma das possíveis combinações de genes, apresentadas na tabela 4, foram analisadas quanto à presença de pelo menos um dos genes de cada dupla possível, ou seja, aaiA e/ou aaiG, aaiA e/ou aaiC, aaiA e/ou aaiU, aaiC e/ou aail, aaiC e/ou aaiG e aaiU e/ou aaiG. Essa análise considerou a tentativa de empregar dois desses genes em combinação na PCR multiplex. Do total de 103 amostras aaiA e/ou aaiG foram detectados em 42, aaiA e/ou aaiC em 51, aaiA e/ou aaiU em 43, aaiC e/ou aail em 50, aaiC e/ou aaiG em 51 e aail e/ou aaiG em 42 amostras.

Desse modo a utilização do gene aaiC junto a aaiA ou aaiG seriam boas opções para compor a PCR multiplex para a detecção de EAEC de ambos os grupos. Entretanto, os iniciadores para aaiC utilizados neste estudo amplificam um fragmento de $278 \mathrm{pb}$, o que o deixaria muito próximo ao amplicon do gene agg $R$ (346 pb) na eletroforese em gel de agarose. Além disso, aaiC foi detectado em uma amostra de EPEC atípica e em uma de ETEC. Por outro lado, os genes aaiA e aaiG foram os mais prevalentes em ambos os grupos de EAEC (45,6\% para aaiA e $42,7 \%$ para aaiG) e em conjunto detectariam 42 amostras (30 típicas e 12 atípicas), resultados promissores para a composição da PCR multiplex junto aos genes plasmidiais aatA e aggR.

\subsection{PCR multiplex utilizando os genes aaiA, aaiG, aggR e aatA}

Os genes aggR e aat $A$ já foram utilizados por outros autores como alternativa para diagnóstico molecular de EAEC através de PCR multiplex, porém em conjunto com o gene aap (dispersina), o que diminui a especificidade do teste considerando que aap não é exclusivo de EAEC (MONTEIRO et al., 2009).

Há descrição na literatura de iniciadores para o gene aggR que têm sido amplamente utilizados com sucesso em diversos estudos, amplificando um fragmento de $308 \mathrm{pb}$ em ciclo de amplificação com temperatura de anelamento de $50^{\circ} \mathrm{C}$. Dessa forma os iniciadores utilizados para os genes aaiA, aaiG e aat $A$ foram testados nos ciclos de amplificação descritos na tabela 2 , mas com temperatura de 
anelamento de $50^{\circ} \mathrm{C}$. Entretanto, os iniciadores para os genes aaiG e aatA não anelaram ou geram fragmentos de DNA inespecíficos, inviabilizando a utilização dessa temperatura no ciclo de amplificação.

Por esse motivo foram realizados ensaios de padronização com os iniciadores descritos na literatura para o gene aggR (CZECZULIN et al., 1999) em temperaturas de anelamento maiores do que $50^{\circ} \mathrm{C}$ e os resultados foram negativos, ou seja, não houve amplificação de fragmentos.

Dessa forma, novos iniciadores para o gene aggR foram desenhados neste estudo, com base na sequência da amostra protótipo EAEC 042 (Número de acesso no GenBank: FN554767). As sequências destes iniciadores estão descritas na tabela 3. Esses novos iniciadores de aggR foram eficientes na temperatura de anelamento de $56{ }^{\circ} \mathrm{C}$, permitindo a utilização na PCR multiplex. A figura 5 ilustra a amplificação de um único fragmento específico de 346 pb, tamanho esperado para estes iniciadores.

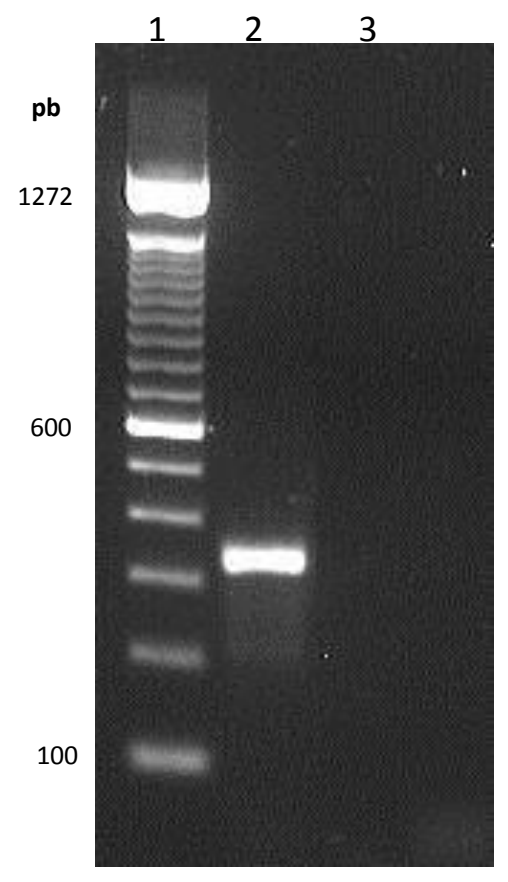

Figura 5 - Eletroforese em gel de agarose (1\%) do produto da PCR para detecção de aggR. Canaletas: 1 - 100 pb DNA Ladder (Invitrogen); 2 - amostra 042 (controle positivo); 3 - amostra DH5a (controle negativo).

O amplicon correspondente a esses novos iniciadores para aggR foi sequenciado e a sua sequência analisada mostrando $99 \%$ de identidade com o mesmo fragmento da sequência de aggR da amostra EAEC 042 depositada no 
GeneBank (número de acesso: FN554767). A figura 6 mostra a sequência de 320 nucleotídeos obtida para o gene aggR, alinhada com a respectiva sequência da amostra protótipo 042 depositada no GeneBank.

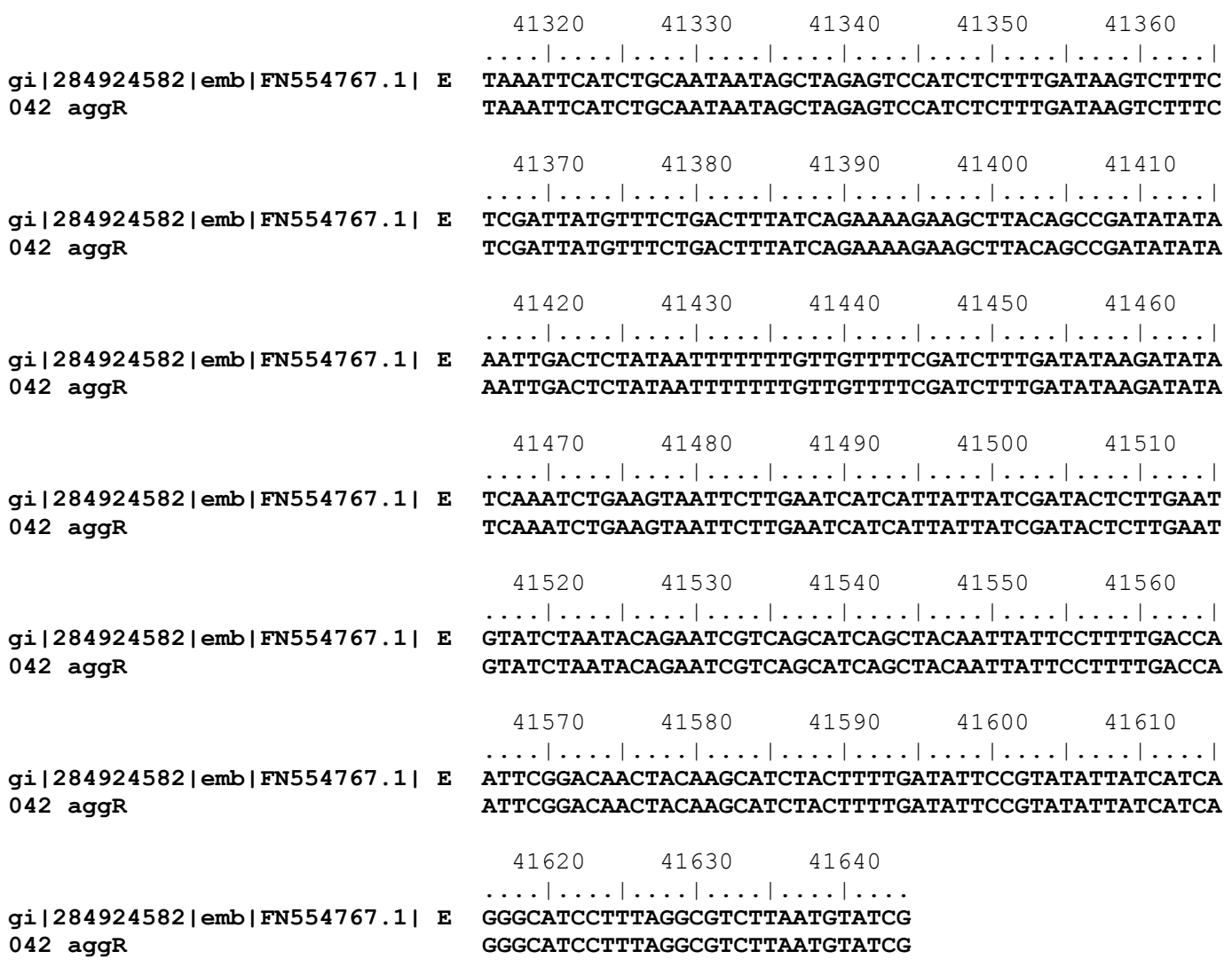

Figura 6 - Alinhamento da sequência parcial de nucleotídeos do gene aggR. Sequência do amplicon aggR deste estudo e a correspondente sequência parcial do gene aggR da amostra protótipo EAEC 042 (№ de acesso no GenBank: FN554767).

Uma vez que os resultados apontaram para a escolha dos genes cromossômicos aaiA e aaiG, a etapa seguinte deste estudo constituiu na padronização da detecção simultânea de aat $A$, aggR, aaiA e aaiG. Primeiramente foram avaliadas diferentes temperaturas de anelamento entre 54 e $58^{\circ} \mathrm{C}$ e foi observado que na temperatura de anelamento de $56{ }^{\circ} \mathrm{C}$ os quatro genes em conjunto foram amplificados separadamente de maneira correta.

Em seguida foi determinada a concentração ideal de iniciadores na reação, realizando uma titulação de diferentes concentrações desses iniciadores para cada um dos genes separadamente. As seguintes concentrações em pmol foram 
utilizadas: 10 pmol, 20 pmol, 30 pmol, 40 pmol, 50 pmol, 60 pmol, 70 pmol, 80 pmol, 90 pmol e 100 pmol, obtendo-se fragmentos específicos nas concentrações de 20 pmol para aaiA, aaiG e agg $R$ e de $50 \mathrm{pmol}$ para aatA (Tabela 6).

Tabela 6 - Sequências dos iniciadores, ciclo de amplificação e concentração (pmol) dos iniciadores utilizados na PCR multiplex

\begin{tabular}{|c|c|c|c|c|}
\hline Gene & $\begin{array}{l}\text { Sequência dos iniciadores } \\
\left(5^{\prime}-3^{\prime}\right)\end{array}$ & $\begin{array}{c}\text { Concentração } \\
\text { dos } \\
\text { iniciadores }\end{array}$ & $\begin{array}{c}\text { Ciclo de } \\
\text { amplificação }\end{array}$ & Referências \\
\hline aaiA & $\begin{array}{l}\text { (F) CCCACGACCAGATAACG } \\
\text { (R) } \\
\text { GTTTTCAGGATTGCCATTAG }\end{array}$ & $20 \mathrm{pmol}$ & & Dudley et al. (2006b) \\
\hline aaiG & $\begin{array}{l}\text { (F) } \\
\text { GGGAGTGTTTCAGTCTGGAC } \\
\text { (R) }\end{array}$ & $20 \mathrm{pmol}$ & & Este estudo \\
\hline $\operatorname{agg} R$ & $\begin{array}{l}\text { (F) } \\
\text { CGATACATTAAGACGCCTAA } \\
\text { AG } \\
\text { (R) } \\
\text { TCTGATACATTAAATTCATCT } \\
\text { GC }\end{array}$ & $20 \mathrm{pmol}$ & $\begin{array}{l}94^{\circ} \mathrm{C} / 1 \mathrm{~min}, \\
56^{\circ} \mathrm{C} / 1 \mathrm{~min}, \\
72^{\circ} \mathrm{C} / 7 \mathrm{~min}\end{array}$ & Este estudo \\
\hline aatA & $\begin{array}{l}\text { (F) } \\
\text { CTGGCGAAAGACTGTATCAT } \\
\text { (R) } \\
\text { CAATGTATAGAAATCCGCTG } \\
\text { TT }\end{array}$ & $50 \mathrm{pmol}$ & & Schimidt et al. (1995) \\
\hline
\end{tabular}

$(\mathrm{F})$ iniciador forward; $(\mathrm{R})$ iniciador reverse.

Inicialmente, a PCR multiplex foi padronizada empregando como controle positivo o DNA das amostras protótipo de EAEC 042 e 17-2, ambas positivas para os quatro genes. Conforme apresentado na figura 7 , houve amplificação dos quatro fragmentos nos tamanhos esperados, ou seja, $782 \mathrm{pb}$ para aaiG, $630 \mathrm{pb}$ para aat $A$, $476 \mathrm{pb}$ para aaiA e $346 \mathrm{pb}$ para agg $R$. 


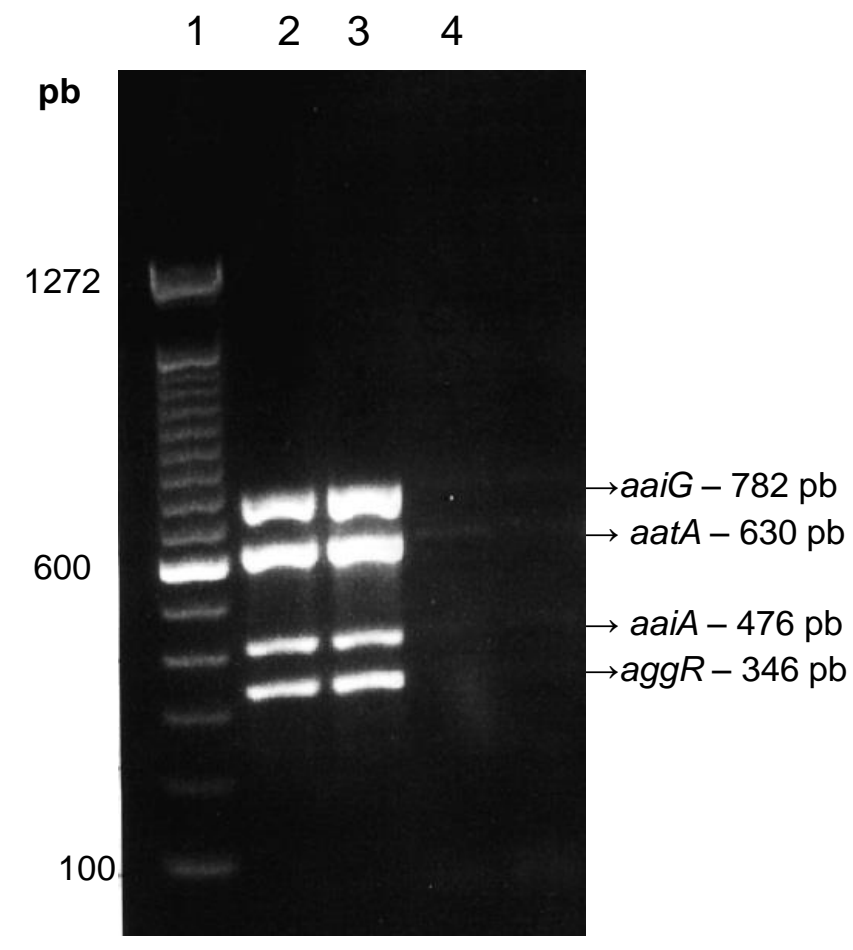

Figura 7 - Eletroforese em gel de agarose (1\%) dos produtos da PCR multiplex para detecção de aaiG, aatA, aaiA e aggR. Canaletas: 1 - 100 pb DNA Ladder (Invitrogen); 2 - amostra 042; 3 - amostra 17-2; 4 - amostra DH5a.

A fim de avaliar a concentração mínima de DNA detectável pela PCR multiplex (limite de detecção) foram realizadas reações com diferentes concentrações de DNA genômico purificado da amostra 042. Conforme apresentado na figura 8, utilizando entre 0,125 e $5 \mu \mathrm{g}$ de DNA, todos os genes foram amplificados. A partir de $0,1 \mu \mathrm{g}$ o gene aggR não foi mais detectado, enquanto os outros três genes continuaram sendo detectados. Desta forma, foi considerado como limite de detecção a concentração de $0,125 \mu \mathrm{g}(125 \mathrm{ng})$ de DNA genômico purificado da amostra EAEC 042 

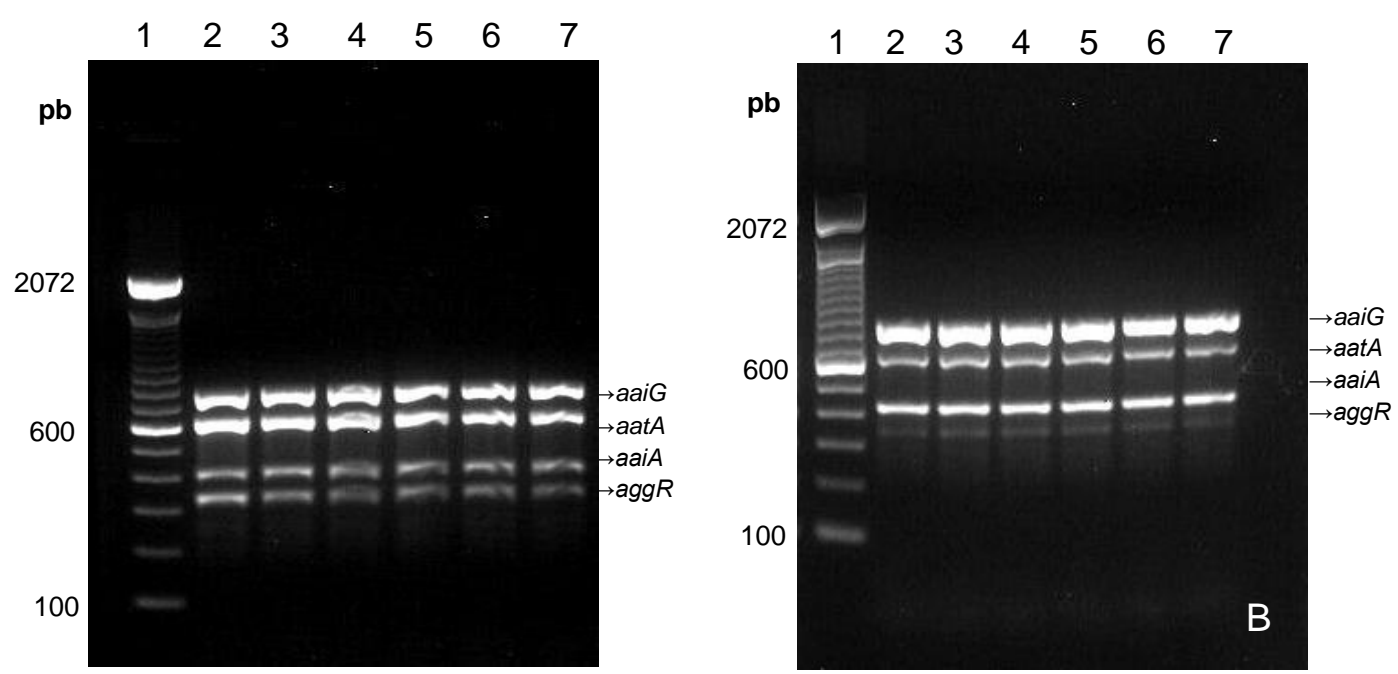

Figura 8 - Eletroforese em gel de agarose (1\%) dos produtos da PCR multiplex para detecção de aaiG, aatA, aaiA e agg $R$ utilizando DNA purificado da amostra EAEC 042 em diversas concentrações. (A) Canaletas: 1 - 100 bp DNA Ladder (Invitrogen); 2 - $5 \mu \mathrm{g}$ de DNA; $3-1 \mu \mathrm{g}$ de DNA; $4-0,75 \mu \mathrm{g}$ de DNA; $5-0,5 \mu \mathrm{g}$ de DNA; $6-0,25 \mu \mathrm{g}$ de DNA; 7- 0,125 $\mu \mathrm{g}$ de DNA. (B) Canaletas: 1 - $100 \mathrm{pb}$ DNA Ladder (Invitrogen); 2 - 0,1 $\mu \mathrm{g}$ de DNA; 3 - 0,075 $\mu \mathrm{g}$ de DNA; $4-0,05 \mu \mathrm{g}$ de DNA; 5 - 0,025 $\mu \mathrm{g}$ de DNA; 6 - 0,0125 $\mu \mathrm{g}$ de DNA; 7 - 0,01 $\mu \mathrm{g}$ de DNA; 8 amostra DH5a.

Em seguida a PCR multiplex foi aplicada nas amostras da coleção EAECEPM, com o objetivo de determinar a sua sensibilidade. A reação mostrou-se eficiente na detecção de EAEC típica e atípica. A figura 9 apresenta alguns exemplos de resultados da PCR multiplex empregando as condições de amplificação e concentrações de iniciadores descritas na tabela 6. A reação apresentou a amplificação correta dos quatro amplicons na amostra protótipo 042 (canaleta 19) e ausência de amplificação no controle negativo (canaleta 18). Algumas amostras representativas de EAEC típica e atípica foram incluídas neste gel de agarose, demonstrando a possibilidade de amplificação de um ou vários amplicons. 


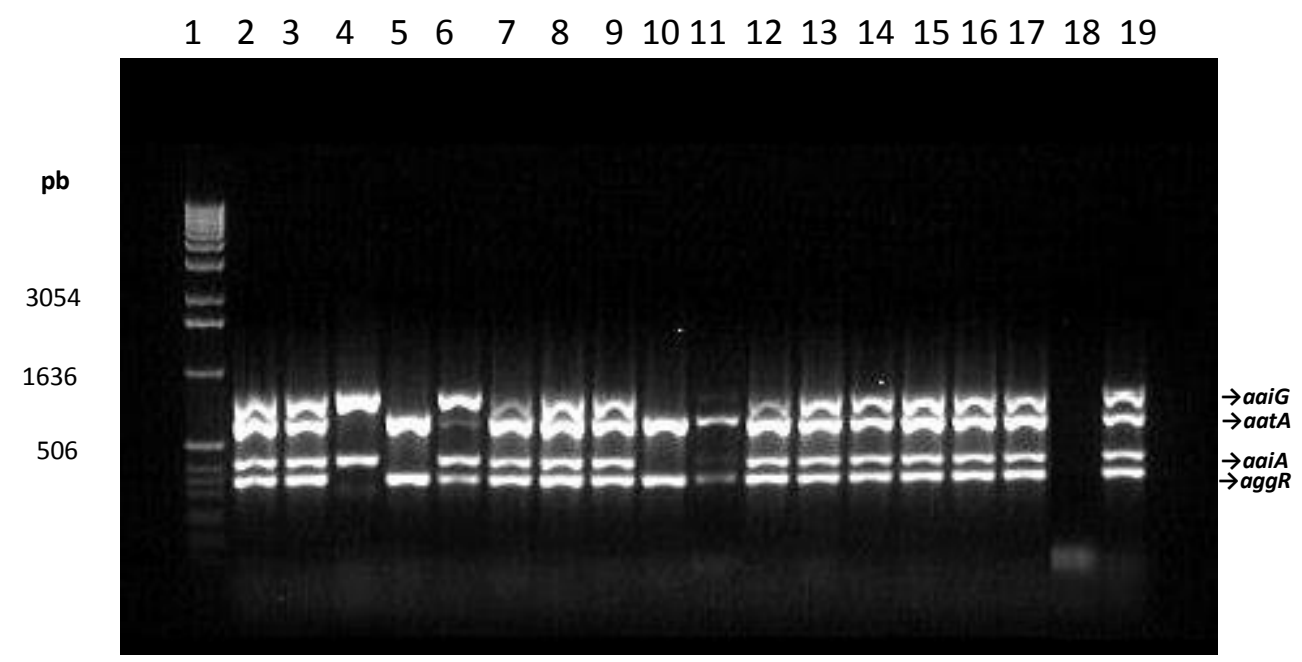

Figura 9 - Eletroforese em gel de agarose (1\%) dos produtos da PCR multiplex com amostras representativas de EAEC típicas e atípicas. Canaletas: $1-1 \mathrm{~kb}$ DNA Ladder (Invitrogen); 2 - amostra 1031-4 (EAEC-EPM); 3 - amostra 1091-1 (EAEC-EPM); 4 - amostra 1191-1 (EAEC-EPM); 5 - amostra 2051-1 (EAECEPM); 6 - amostra 2351-1 (EAEC-EPM); 7 - amostra 3201-2 (EAEC-EPM); 8 amostra 3301-1 (EAEC-EPM); 9 - amostra 3531-3 (EAEC-EPM); 10 - amostra 3621-2 (EAEC-EPM); 11 - amostra 3641-2 (EAEC-EPM); 12 - amostra 3701-1 (EAEC-EPM); 13 - amostra 3861-1 (EAEC-EPM); 14 - amostra 4081-1 (EAECEPM); 15 - amostra 4311-6 (EAEC-EPM); 16 - amostra 4691-2 (EAEC-EPM); 17 - 4981-1; 18 - DH5a (controle negativo); 19 - amostra 042 (controle positivo).

Os resultados obtidos com a PCR multiplex aplicada em todas as amostras EAEC-EPM estão apresentados na figura 10. A positividade do teste foi considerada quando pelo menos um dos quatro genes foi detectado.

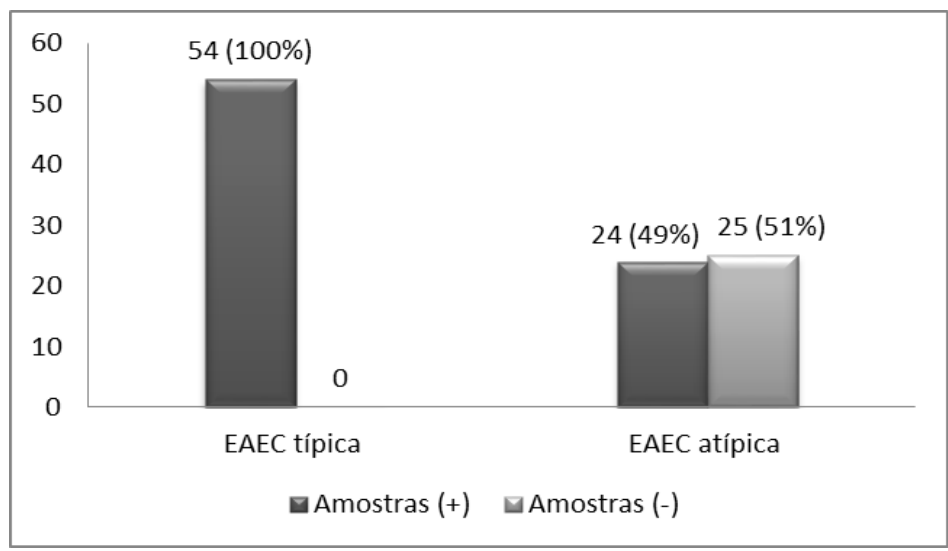

Figura 10 - Avaliação da detecção de EAEC típicas e atípicas pela PCR multiplex. O gráfico demonstra a detecção das amostras de EAEC típica e atípica, através da PCR multiplex. 
Pode-se observar que todas as amostras de EAEC típicas da coleção EAECEPM foram detectadas a partir da PCR multiplex. Com relação às amostras de EAEC atípicas, 24 (49\%) foram detectadas pelo teste padronizado.

\subsection{Sensibilidade e especificidade da PCR multiplex}

As 403 amostras de E. coli fecais pertencentes a patótipos de E. coli diarreiogênica (EPEC, ETEC, EIEC, DAEC, EAEC) e sem marcadores de virulência de $\mathrm{DEC}$ e não aderente em células HEp-2 foram analisadas quanto à reatividade com a PCR multiplex às cegas, ou seja, sem conhecimento da classificação prévia em termos de patótipos. Os testes foram realizados segundo a descrição apresentada na tabela 6.

Do total de amostras analisadas 74 (18,4\%) foram detectadas pelo ensaio de PCR multiplex, considerando como teste positivo a presença de pelo menos um dos quatro genes. Cabe salientar que não houve diferença quanto à origem das amostras, ou seja, 38 foram isoladas de casos e 36 de controles. Dessa forma, todos os resultados foram analisados sem essa distinção.

A maioria das amostras positivas (55 ou 74,3\%) pertencia à categoria EAEC, incluindo as típicas $(\operatorname{agg} R+)$ e atípicas (aggR-). Entretanto, algumas amostras de outros patótipos e amostras desprovidas de marcadores de E. coli diarreiogênicas (19 ou $25,7 \%$ ) também foram detectadas pelo ensaio (Tabela 7 ).

Tabela 7 - Classificação das 74 amostras de E. coli fecais positivas no ensaio de PCR multiplex

\begin{tabular}{cc}
\hline $\begin{array}{c}\text { Classificação das amostras de } E . \\
\text { coli fecais }\end{array}$ & $\mathbf{N}^{\circ}(\%)$ de amostras positivas na PCR multiplex \\
\hline EAEC típica & $39(52,7)$ \\
EAEC atípica & $16(21,6)$ \\
DAEC & $3(4,1)$ \\
EPEC & $4(5,4)$ \\
Não patogênicas* & $12(16,2)$ \\
\hline
\end{tabular}

*Foram consideradas aquelas amostras que não apresentam marcadores de virulência de $E$. coli diarreiogênicas e/ou padrão de adesão em células HEp-2 não característico ou não aderente. 
Dentre as 58 amostras de EAEC incluídas no total de amostras analisadas no teste, 55 (94,8\%) foram detectadas, incluindo 39 típicas (100\%) e 16 (84,2\%) atípicas.

A análise dos resultados das amostras positivas no ensaio de PCR multiplex mostrou que os quatro genes foram detectados em diversas combinações (Tabela 8).

As EAEC típicas detectadas apresentaram os perfis: aaiG/aatA/aaiA/aggR, aatA/aggR e aaiA. As EAEC atípicas foram detectadas pelos seguintes perfis: aaiG/ aatA/aaiA, aaiG/aaiA e aatA.

Dentre as atípicas detectadas pelo teste, 10 foram positivas para os genes cromossômicos aaiA e aaiG somente, desse modo se fossem utilizados apenas os genes plasmidiais aggR e aat $A$ essas amostras não seriam detectadas, sendo assim, houve um aumento de $60 \%$ na detecção de EAEC atípica, com a inserção desses marcadores cromossômicos.

As amostras não classificadas como EAEC e detectadas pelo ensaio apresentaram as seguintes combinações de genes: 8 amostras positivas para aaiG/aaiA (1 DAEC e 7 não patogênicas) e 11 amostras positivas apenas para aaiA (2 DAEC, 4 EPEC e 5 não patogênicas). É importante mencionar que a combinação aaiG/aaiA foi também detectada em 10 EAEC, mas a detecção isolada de aaiA ocorreu em apenas uma EAEC, ao passo que detectou 11 amostras não EAEC.

Tabela 8 - Combinações de genes detectados das 74 amostras de E. coli fecais positivas no ensaio de PCR multilplex e suas classificações

\begin{tabular}{lcl}
\hline $\begin{array}{l}\text { Combinações de } \\
\text { genes detectados }\end{array}$ & $\begin{array}{l}\mathbf{N}^{\circ} \text { (\%) de amostras } \\
\text { positivas }\end{array}$ & $\begin{array}{l}\text { Classificação das amostras (No de amostras } \\
\text { positivas) }\end{array}$ \\
\hline aaiG, aatA, aaiA, aggR & $20(26,7)$ & tEAEC (20) \\
aatA, aggR & $18(25,3)$ & tEAEC (18) \\
aaiG, aaiA & $18(24)$ & aEAEC (10), DAEC (1), não patogênica (7) \\
aaiA & $12(16)$ & tEAEC (1), DAEC (2), EPEC (4), não patogênica (5) \\
aatA & $5(6,7)$ & aEAEC (5) \\
aaiG, aatA, aaiA & $1(1,3)$ & aEAEC (1)
\end{tabular}

* tEAEC, E. coli enteroagregativa típica; aEAEC, E. coli enteroagregativa atípica; E. coli não patogênicas, aquelas amostras que não apresentam marcadores de virulência de $E$. coli diarreiogênicas e/ou padrão de adesão em células HEp-2 não característico ou não aderente. 
Em seguida, de posse desses resultados em confronto com os dados de padrões de adesão em células HeLa e da presença de marcadores de virulência de patótipos de E. coli diarreiogênicas, foi possível calcular os valores de sensibilidade, especificidade, valor preditivo do teste negativo e valor preditivo do teste positivo.

Os verdadeiros positivos (VP) incluíram as amostras de EAEC classificadas a partir da expressão do padrão agregativo em células HEp-2, uma vez que esse é o teste considerado padrão ouro para o diagnóstico de EAEC (NAVARRO-GARCIA; ELIAS, 2011), e que foram detectadas pela PCR multiplex. Cinquenta e cinco amostras foram consideradas como VP (30 de casos e 25 de controles).

Os verdadeiros negativos (VN) incluíram as amostras que não apresentaram padrão de adesão agregativo em células HEp-2 e não foram detectados pela PCR multiplex. Trezentas e vinte e seis amostras foram consideradas VN (160 de casos e 166 de controles).

Os falsos negativos (FN) incluíram as amostras que apresentam padrão de adesão agregativo em células HEp-2, mas não foram detectadas pela PCR multiplex. Três amostras de controles foram consideradas FN.

Os falsos positivos (FP) incluíram as amostras que apresentam padrões de adesão diferentes do agregativo (difuso, localizado, localizado-like, não característico ou não aderente) e que foram detectadas na PCR multiplex. Dezenove amostras foram consideradas FP (8 de casos e 11 de controles).

Dessa forma, o ensaio de PCR multiplex desenvolvido neste estudo apresentou sensibilidade de $94,8 \%$, especificidade de $94,5 \%$, valor preditivo de teste positivo de $74,3 \%$ e valor preditivo de teste negativo de $99,1 \%$. 


\section{DISCUSSÃO}

EAEC é considerada um enteropatógeno emergente por diversos autores, devido a sua associação com diarreia aguda e persistente em crianças e adultos, tanto em países desenvolvidos quanto em desenvolvimento, bem como a surtos de diarreia e a diarreia do viajante (ESTRADA-GARCIA; NAVARRO-GARCIA, 2012; HARRINGTON et al., 2006; HUANG et al., 2006).

Os aspectos genotípicos e fenotípicos de virulência mostram que EAEC é um patótipo heterogêneo, ou seja, não há um marcador comum a todas as amostras que compõem o grupo, dificultando a compreensão da sua patogênese (BOISEN et al., 2012; CZECZULIN et al., 1999; HUANG et al., 2007; NATARO, 2005; VILA et al., 2000). Nesse sentido houve a proposta de subdivisão do patótipo EAEC nos grupos típica e atípica, partindo da premissa de que o grupo das típicas seria constituído de amostras com maior potencial de virulência visto que albergam um maior número de genes de virulência sob regulação de AggR (NATARO, 2005; SARANTUYA et al., 2004).

Contudo, vários estudos epidemiológicos apontam que a frequência de EAEC atípica como agente de diarreia aguda é significativa, em alguns casos superior a de EAEC típica (Tabela 1). Além disso, uma amostra de EAEC atípica foi responsável por um surto hospitalar de diarreia na Sérvia (COLBEJIC et al., 1996; DUDLEY et al., 2006a).

Esses estudos empregaram diferentes metodologias para classificar as bactérias como EAEC, mas em todos houve a detecção do gene aggR. Resumidamente, EAEC atípica foi detectada em frequências superiores a EAEC típica (HUANG et al., 2003; HUANG et al., 2007; MONFARDINI, 2012), similares (JIANG et al., 2002) ou inferiores (ARAUJO et al., 2007; ASLANI et al., 2010; BOISEN et al., 2012;ELIAS et al., 2002; ZAMBONI et al., 2004).

Nesses estudos nota-se que a metodologia utilizada para a classificação das amostras interfere no resultado da frequência de EAEC atípica. Por exemplo, Araujo et al. (2007) utilizaram aatA como sonda genética para a detecção de EAEC obtendo então $100 \%$ de amostras típicas. Porém, outros autores que utilizaram a sonda CVD432 (aatA) em conjunto com o ensaio de adesão em células epiteliais (HeLa ou 
HEp-2) detectaram EAEC atípica (ASLANI et al., 2010; GOMES et al., 1998). Já nos estudos em que as EAEC atípicas foram mais frequentes do que EAEC típicas a metodologia utilizada foi o teste de adesão em células epiteliais (JIANG et al., 2002; HUANG et al., 2003; HUANG et al., 2007).

Tendo em vista que a frequência de EAEC atípica é significativa, inclusive em nosso meio (CORDEIRO et al., 2008; GIOPPO et al., 2000; GOMES et al., 1998; MONFRADINI, 2012; PIVA 2003; LIMA et al., 2013b; ZAMBONI et al., 2004), tornase necessário que essas cepas também sejam detectadas.

O diagnóstico de EAEC considerado como padrão ouro é a observação da expressão do fenótipo de adesão agregativa em células HeLa ou HEp-2 (NATARO; KAPER; 1998). Porém, como já mencionado anteriormente, esse ensaio demanda de infraestrutura laboratorial específica disponível apenas em laboratórios de referência. Por esse motivo surgiram alguns diagnósticos moleculares para EAEC, como tentativa para substituir os ensaios de adesão.

Dentre eles destacam-se os testes de PCR que se fundamentam na detecção de fatores de virulência associados à EAEC. Alguns utilizam a PCR multiplex detectando simultaneamente mais de um marcador de virulência desse patótipo (CERNA et al., 2003; JENKINS et al., 2006b; RÜTTLER et al., 2006). Entretanto, como no ensaio descrito por Cerna et al. (2003), somente marcadores plasmidiais são detectados, o que não permite a detecção de EAEC atípicas. Além disso, o gene aap utilizado por esses autores não é específico para EAEC (MONTEIRO, et al., 2009). Já no teste descrito por Jenkins et al. (2006b) foram utilizados genes plasmidiais e cromossômicos (presentes na PAl pheU) associados a EAEC, mas esses autores incluíram o gene astA (enterotoxina EAST-1) que é altamente prevalente em outros patótipos de DEC, bem como em outras enterobactérias (SAVARINO et al., 1996).

Dessa forma, no presente estudo foram selecionados quatro genes cromossômicos (aaiA, aaiC, aaiG e aail) de uma PAI descrita na amostra protótipo de EAEC 042 (DUDLEY et al., 2006) para a escolha de pelo menos dois dentre eles que fossem específicos e frequentes em EAEC. Esses dois genes seriam então, em conjunto com aggR e aatA, usados em uma PCR multiplex para a deteç̧ão de EAEC típica e atípica. 
A PAl que contém esses genes apresenta $117 \mathrm{~kb}$, está inserida no locus do tRNA pheU no cromossomo da amostra 042 e apresenta 25 genes (de aaiA até aaiY) (DUDLEY et al., 2006). Muitos desses genes apresentam homologia com genes de outras bactérias Gram negativas que possuem um sistema de secreção do tipo VI, tal como IcmF-Associated Homologous Proteins (IAHP) em Vibrio cholerae (PUKATZKI et al., 2006).

A contribuição dos produtos dos genes aai na patogênese de EAEC ainda é desconhecida, porém essas proteínas aparentemente não têm papel na aderência da bactéria a superfícies abióticas ou das células epiteliais intestinais, como ocorre com outros genes regulados por AggR (BOISEN et al., 2012; HARRINGTON et al., 2006; JENKINS et al., 2006a; LIMA et al., 2013a; TANIUCHI et al., 2012).

Diversos estudos mostraram que aaiA e aaiC são comumente encontrados em isolados de EAEC, particularmente em amostras de EAEC típica, o que sustenta a hipótese de que o sistema de secreção do tipo VI seja um mediador da patogenicidade dessas bactérias (DUDLEY et al., 2006).

Alguns autores já utilizaram genes da PAl inserida em pheU como uma tentativa de detecção molecular de EAEC. Jenkis et al. (2006a) utilizaram no ensaio de PCR o gene aaiA, além de outros genes cromossômicos, com o objetivo de caracterizar um perfil genético para amostras de EAEC. O gene aaiA foi detectado em $48,9 \%$ das amostras de EAEC e em $3 \%$ das não classificadas como EAEC, demonstrando sua alta frequência nesse patótipo de DEC. Em outro estudo Jenkis et al. (2006b) realizaram uma PCR multiplex contendo também o gene aaiA e detectaram $36 \%$ de amostras positivas para este gene.

Recentemente Boisen et al. (2012) descreveram quatro distintas PCR multiplex que detectam 21 potenciais genes de virulência de EAEC, entre eles os genes plasmidiais aggR, aatA e aap e o cromossômico aaiC. Porém, a PCR multiplex desse estudo teve como objetivo a caracterização genômica de uma coleção de EAEC isoladas de crianças com diarreia, não envolvendo diretamente o diagnóstico. Os genes agg $R$, aatA e aaiC foram detectados em $69,4 \%, 68,6 \%$ e $47,9 \%$ das amostras, respectivamente.

Assim, no presente estudo foram obtidos resultados semelhantes aos disponíveis na literatura, ou seja, aaiA esteve presente em 45,6\% das EAEC, e o 
gene aaiC em 38,8\%. Já para os genes aaiG e aaiU, não há dados na literatura para comparação, mas foi observado que aaiG também tem uma boa frequência em amostras de EAEC (46\% das amostras estudadas).

Entretanto, quando esses dados foram analisados separadamente com relação aos grupos de EAEC típicas e atípicas, os resultados mostraram frequências inferiores a $30 \%$ no grupo das atípicas. Por esse motivo outros genes cromossômicos foram pesquisados como alternativa para uma maior frequência em EAEC atípicas. Foram selecionados então os genes air e pheU4529, também localizados no cromossomo da EAEC 042 (CHAUDHURI et al., 2010; DUDLEY et al., 2006; SHEIKH et al., 2006).

O gene air está localizado em uma PAI inserida no tRNA glyU e codifica uma proteína que tem similaridade significativa com intiminas e invasinas (SHEIKH et al., 2006).

Para verificar a frequência do gene air nas amostras EAEC-EPM foram desenhados iniciadores de acordo com a sequência correspondente ao gene da amostra protótipo EAEC 042 (número de acesso no GenBank: FN554766) e estabelecida a PCR. Entretanto, não foi possível padronizar a reação mesmo utilizando diferentes ciclos de amplificação e concentrações de iniciadores e componentes da PCR. O fragmento amplificado (806 pb) foi sempre acompanhado de diversas bandas inespecíficas, tanto na amostra 042 como no controle negativo (dados não apresentados).

O outro gene escolhido (pheU4529) codifica uma proteína hipotética do sistema de secreção do tipo VI (DUDLEY et al., 2006). Esse gene foi escolhido porque dentre alguns avaliados por Jenkins et al. (2006a) foi o que apresentou a maior frequência nas amostras de EAEC atípica.

Para verificar a frequência do gene pheU4529 nas amostras EAEC-EPM foram desenhados iniciadores de acordo com a sequência correspondente ao gene da amostra protótipo EAEC 042 (número de acesso no GenBank: FN554766) e estabelecida a PCR. Não houve diferença significativa entre os obtidos anteriormente com os genes aaiG e aaiA, ou seja, pheU4529 foi detectado em 16 (32,6\%) EAEC atípicas e em 25 (46,3\%) típicas. Porém, na etapa de verificação da frequência desse gene nas coleções DEC-IBu, ENTEROBAC-IBu e Microbiota, a 
PCR apresentou diversas bandas inespecíficas quando o gene de interesse estava presente (dados não apresentados).

Esses resultados inviabilizaram a utilização de ambos os genes em uma PCR multiplex para diagnóstico. Dessa forma o presente trabalho teve continuidade utilizando os genes aaiA e aaiG na composição da PCR multiplex em conjunto com os genes plasmidiais aatA e aggR.

Os genes aggR e aatA já tiveram suas frequências determinadas utilizando PCR multiplex como ferramenta para o diagnóstico desse patótipo, mostrando que esses genes são prevalentes em cepas de EAEC (ARANDA, et al., 2007; BOUZARI et al., 2005; CERNA et al., 2003; FUJIOKA et al., 2009; MÜLLER et al., 2007; RÜTLER et al., 2006; SAMIE et al., 2007; TOMA et al., 2002). Monteiro et al. (2009) em seu estudo verificaram também a prevalência dos genes aat $A$ e aggR em outras amostras de DEC (com exceção de EAEC) e os mesmos não foram detectados, o que demonstra a especificidade desses genes em bactérias pertencentes a esta categoria. Por tal motivo esses dois genes plasmidiais foram utilizados para compor a PCR multiplex estabelecida junto aos genes cromossômicos aaiA e aaiG.

Recentemente diversos autores desenvolveram PCRs multiplex como alternativa de diagnóstico rápido e simultâneo para diversos patótipos de DEC, incluindo EAEC (ARANDA et al., 2004; ARANDA et al., 2007; GUION et al., 2008; FUJIOKA et al., 2009; LIMA et al., 2012; PANCHALINGAM et al., 2012; SOUZA et al., 2013; TANIUCHI et al., 2012; TOMA et al., 2003).

Empregando a detecção de vários marcadores de virulência, alguns desses estudos detectaram EAEC com base na presença do gene aggR (ARANDA et al., 2007; GUION et al., 2008; TOMA et al., 2003), aatA (ARANDA et al., 2004; BISCHOFF et al., 2005; SOUZA et al., 2013) ou de aggR e astA (FUJIOKA et al., 2009). Porém, aggR ou aatA detectam apenas EAEC típica (KAPER et al., 2004) e astA não é específico para EAEC (SAVARINO et al., 1996). Além disso, os resultados de Toma et al. (2003), mostraram claramente que a PCR multiplex usando apenas aggR não detectou amostras de EAEC atípica.

Outros ensaios do tipo multiplex para o diagnóstico de patótipos de DEC detectaram EAEC usando os genes aatA e aaiC, aumentando assim a detecção de 
EAEC que não albergam o plasmídio pAA, devido à inclusão de aaiC (LIMA et al., 2012; PANCHALINGAM et al., 2012; TANIUCHI et al., 2012).

A PCR multiplex composta por aaiA, aaiG, aatA e aggR desenvolvida no presente trabalho foi avaliada inicialmente em uma coleção unicamente composta por amostras de EAEC, onde se mostrou uma excelente alternativa para a detecção dessas amostras. Isso pôde ser evidenciado pelos dados obtidos com a coleção EAEC-EPM, onde sem os marcadores cromossômicos a porcentagem de detecção seria 52,4\% (54 EAEC típicas). Já com a inclusão dos marcadores cromossômicos essa taxa passou para 75,7\% (54 EAEC típicas e 24 atípicas), ou seja, um aumento de $44,4 \%$ na detecção.

Em seguida o ensaio de PCR multiplex desenvolvido neste estudo foi avaliado na detecção de EAEC em uma grande coleção de amostras de E. coli fecais previamente classificadas como DEC ou não patogênicas, permitindo o cálculo dos valores de sensibilidade, especificidade e valores preditivos de teste positivo e negativo. Essa abordagem é pouco aplicada nos trabalhos de diagnóstico de EAEC descritos na literatura. Quando o valor de sensibilidade é citado, geralmente referese ao limite de detecção da técnica.

O teste aqui desenvolvido apresentou valores excelentes de sensibilidade $(94,8 \%)$, especificidade $(94,5 \%)$ e de valor preditivo de teste negativo $(99,1 \%)$, ou seja, a chance de uma amostra realmente negativa tende a ser diagnosticada pelo teste como negativa. Não há muitos dados na literatura analisando a sensibilidade e a especificidade de ensaios de PCR para a detecção de EAEC. O ensaio de PCR multiplex empregando os genes aggR, aatA e aap (dispersina) descrito por Cordeiro et al. (2008) apresentou os valores de $93,5 \%$ de sensibilidade, $81 \%$ de especificidade e $95,3 \%$ de valor preditivo do teste negativo, semelhantes aos encontrados no presente trabalho. Outros estudos descreveram ensaios de PCR multiplex (aggR, aatA e aap), mas não calcularam esses valores, uma vez que só empregaram amostras de EAEC, definidas pela expressão do padrão agregativo em células epiteliais cultivadas (BOUZARI et al., 2005; CERNA et al., 2003). No estudo de Taniuchi et al. (2012) os valores de sensibilidade e especificidade são descritos, entretanto, quando o ensaio é comparado na detecção de EAEC a partir de colônias isoladas, do cultivo em caldo de enriquecimento ou diretamente das fezes. 
Já o valor preditivo de teste positivo, representando a chance de que uma amostra realmente positiva seja diagnosticada pelo teste como positiva, apresentou valor mais baixo que os outros indicadores $(74,3 \%)$, mas semelhante $(75,2 \%)$ ao obtido também no estudo de Cordeiro et al. (2008).

Esse valor foi mais baixo em decorrência das 19 amostras consideradas "falsos positivos", ou seja, amostras de DAEC, EPEC e não patogênicas diagnosticadas pelo teste. Dentre elas, 11 apresentaram somente o gene aaiA, o qual foi detectado isoladamente em apenas uma EAEC. Dessa forma, o achado isolado de aaiA deve ser considerado com precaução. A análise de uma coleção mais ampla de amostras de EPEC e DAEC através do ensaio de PCR multiplex permitirá a confirmação de que 0 achado isolado de aaiA nesse teste deva ser considerado como um resultado negativo.

O ensaio desenvolvido detectou 39 EAEC típicas (100\%) e 16 atípicas $(84,2 \%)$. Cabe salientar que dentre as atípicas detectadas, 10 foram positivas apenas para os genes cromossômicos aaiA e aaiG. Desse modo, se fossem utilizados apenas os genes plasmidiais (aggR e aat $A$ ) essas amostras não seriam detectadas. Portanto, houve um aumento de $60 \%$ na detecção de EAEC atípica com a inserção desses marcadores cromossômicos.

$O$ fato de ter havido um aumento na detecção de EAEC atípica na coleção estudada demonstra que a inserção dos genes cromossômicos (aaiA e aaiG) no ensaio de PCR multiplex para o diagnóstico de EAEC torna o teste mais abrangente, ou seja, amostras que anteriormente não seriam detectadas utilizando os genes aggR e/ou aatA têm maior probabilidade de serem reveladas com a utilização dos genes cromossômicos, demonstrando mais uma vez a eficiência da PCR multiplex proposta.

Nos laboratórios clínicos do nosso país a identificação dos patótipos de DEC na coprocultura é baseada na soroaglutinação de cepas de $E$. coli com antissoros polivalente que detectam os sorogrupos clássicos de EPEC, de EIEC e o sorogrupo O157 de EHEC (LEVY; VAZ, 2010). Essa técnica de diagnóstico além de não detectar EAEC, também exclui EPEC atípicas (não pertencentes aos sorogrupos clássicos de EPEC), DAEC, ETEC e outros sorogrupos de STEC (HERNANDES et al., 2009; NATARO; KAPER, 1998). 
$\mathrm{Na}$ tentativa de ampliar esse esquema diagnóstico o Laboratório de Bacteriologia do Instituto Butantan vem desenvolvendo um ensaio imunocromatográfico empregando anticorpos específicos para o diagnóstico de EPEC, ETEC e STEC (ROCHA, 2012). O patótipo EAEC não pôde ser incluído nesse diagnóstico devido à falta de um fator de virulência comum à maioria das cepas desse grupo.

A adição da PCR multiplex para EAEC ao teste imunocromatográfico permitiria a detecção dos quatro patótipos de DEC mais prevalentes em nosso meio (GUTH et al., 2010).

Segundo Mosammaparast et al. (2012) testes moleculares para a detecção de doenças infecciosas são cada vez mais comuns e devem ser executados no próprio laboratório clínico, ao invés de restritos a centros de referência. Embora essa técnica apresente limitações pela necessidade de um aparelho termociclador e de aparato para a eletroforese em gel de agarose, grande parte dos laboratórios clínicos de médio e grande porte já dispõe dessa tecnologia em nosso país.

A proposta de PCR multiplex para a detecção de EAEC típica e atípica representa uma possibilidade de melhora no diagnóstico de DEC em laboratórios clínicos. O teste proposto neste projeto mostrou uma alta sensibilidade e especificidade e dessa forma pode ser considerado como uma boa alternativa para o diagnóstico de EAEC tanto típica como atípica, a partir de colônias isoladas na coprocultura e já identificadas como E. coli.

Um avanço na proposta do ensaio de PCR multiplex para detecção de EAEC típica e atípica será a sua avaliação em colônias isoladas diretamente de meios de cultura seletivos (sem identificação bioquímica de $E$. coll) e também diretamente das fezes. Essas propostas terão continuidade por nosso grupo. 


\section{CONCLUSÃO}

O teste de PCR multiplex desenvolvido apresentou alta sensibilidade e especificidade para o diagnóstico de EAEC a partir de colônias isoladas de E. coli e permitiu um acréscimo na detecção de EAEC atípica. 


\section{REFERÊNCIAS}

ADACHI, J. A.; ERICSSON, C. D.; JIANG, Z. D.; DUPONT, M. W.; PALLEGAR, S. R.; DUPONT, H. I. Natural history of enteroaggregative and enterotoxigenic Escherichia coli infection among US travelers to Guadalajara, Mexico. J. Infect. Dis., v. 185, p. 16811683, 2002.

AFSET, J. E.; BEVANGER, L.; ROMUNDSTAD, P.; BERGH, K. Association of atypical enteropathogenic Escherichia coli (EPEC) with prolonged diarrhoea. J. Med. Microbiol., v. 53, p. 1137-1144, 2004.

ARANDA, K. R.; FABBRICOTTI, S. H.; FAGUNDES-NETO, U.; SCALETSKY, I.C. Single multiplex assay to identify simultaneously enteropathogenic, enteroaggregative, enterotoxigenic, enteroinvasive and Shiga toxin-producing Escherichia coli strains in Brazilian children. FEMS Microbiol. Lett., v. 267, p. 145-150, 2007.

ARANDA, K. R.; FAGUNDES-NETO, U.; SCALETSKY, I. C. Evaluation of multiplex PCRs for diagnosis of infection with diarrheagenic Escherichia coli and Shigella spp. J. Clin. Microbiol., v. 42, p. 5849-5853, 2004.

ARAUJO, J. M.; TABARELLI, G. F.; ARANDA, K. R.; FABBRICOTTI, S. H.; FAGUNDESNETO, U.; MENDES, C. M.; SCALETSKY, I. C. Typical enteroaggregative and atypical enteropathogenic types of Escherichia coli are the most prevalent diarrhea-associated pathotypes among Brazilian children. J. Clin. Microbiol., v. 45, p. 3396-3999, 2007.

ASLANI, M. M.; ALIKHANI, M. Y.; ZAVARI, A.; YOUSEFI, R.; ZAMANI, A. R. Characterization of enteroaggregative Escherichia coli (EAEC) clinical isolates and their antibiotic resistance pattern. Int. J. Infect. Dis., v. 15, p. 136-139, 2010.

BANDO, S. Y.; ANDRADE, F. B.; GUTH, B. E. C.; ELIAS, W. P.; MOREIRA-FILHO, C. A. PESTANA DE CASTRO A. F. Atypical enteropathogenic Escherichia coli genomic background allows the acquisition of non-EPEC virulence factors. FEMS Microbiol. Lett., v. 299, p. 22-30, 2009.

BAUDRY, B.; SAVARINO, S. J.; VIAL, P.; KAPER, J. B.; LEVINE, M. M. A sensitive and specific DNA probe to identify enteroaggregative Escherichia coli, a recently discovered diarrheal pathogen. J. Infect. Dis., v. 161, p. 1249-1251, 1990.

BENZ, I.; SCHMIDT, M. A. AIDA-I, the adhesin involved in diffuse adherence of the diarrhoeagenic Escherichia coli strain 2787 (O126:H27), is synthesized via a precursor molecule. Mol. Microbiol., v. 6, p. 1539-1546, 1992.

${ }^{*}$ De acordo com:

ASSOCIAÇÃO BRASILEIRA DE NORMAS TÉCNICAS. NBR 6023: informação e documentação:

referências: elaboração. Rio de Janeiro, 2002. 
BERGAN, J.; DYVE LINGELEM, A. B.; SIMM, R.; SKOTLAND, T.; SANDVIG, K. Shiga toxins. Toxicon., v. 60, p. 1085-1107, 2012.

BERNIER, C.; GOUNON, P.; LE BOUGUÉNEC, C. Identification of an aggregative adhesion fimbria (AAF) type III-enconding operon in enteroaggregative Escherichia coli as a sensitive probe for detecting the AAF-enconding operon family. Infect. Immun., v. 70, p. 4302-4311, 2002.

BHAN, M. K.; BHATNAGAR, S. Persistent diarrhea in infants and young children. Indian Pediatr., v. 30, p. 147-151, 1993.

BIELASZEWSKA, M.; MELLMANN, A.; ZHANG, W.; KÖCH, R.; FRUTH, A.; BAUWENS, A.; PETERS, G.; KARCH, H. Characterisation of the enteroaggregative Escherichia coli strain associated with an outbreak of haemolytic uraemic syndrome in Germany, 2011: a microbiological study. Lancet Infect. Dis., v. 11, p. 671-676, 2011.

BILGE, S. S.; CLAUSEN, C. R.; LAU, E.; MOSELEY, S. T. Molecular characterization of fimbrial adhesion, F1845, mediating diffuse adherence of diarrhea-associated Escherichia coli to HEp-2 cells. J. Bacteriol., v. 171, p. 4281-4289, 1989.

BISCHOFF, C.; LÜTHY, J.; ALTWEGG, M.; BAGGI F. Rapid detection of diarrheagenica E. coli by real-time PCR. J. Microbiol. Methods, v. 61, p. 355-341, 2005.

BLACK, R. E; COUSESNS, S.; JOHNSON, H. L.; LAWN, J. E.; RUDAN, I.; BASSANI, D. G.; JHA, P.; CAMPBELL, H.; WALKER, C. F.; CIBULSKIS, R.; EISELE, T.; LIU, L.; MATHERS, C. Global, regional, and national causes of child mortality in 2008: a systematic analysis. Lancet, v. 375, p. 1969-1987, 2010.

BOISEN, N.; StRUVE, C.; SCHEUTZ, F.; KROGFELT, K. A.; NATARO J. P. New adhesion of enteroaggregative Escherichia coli related to the Afa/Dr/AAF family. Infect. Immun., v. 76, p. 281-292, 2008.

BOISEN, N.; SCHEUTZ, F.; RASKO, D. A.;REDMAN, J. C.; PERSSON, S.; SIMON, J.; KOTLOFF, K.L.; LEVINE, M.M.; SOW, S.; TAMBOURA, B.; TOURE, A.; MALLE, D.; PANCHALINGAM, S.; KROGFELT, K.A.; NATARO, J.P. Genomic characterization of enteroaggregative Escherichia coli from children in Mali. J. Infect. Dis., v. 205, p. 431444, 2012.

BOOP, C. A.; BRENNER, F. W.; WELLS, J. G.; STROCKBINE, N. A.; FIELDS, P. I. Escherichia, Shigella and Salmonella. In: MURRAY, P. R.; BARON, E. J.; PFALLER, M. A.; TENOVER, F. C.; YOLKEN, R. H. (Ed.). Manual of clinical microbiology. 8th ed. Washington, D. C.: ASM Press, 2003. cap. 42, v. 1, p. 654-700.

BOUZARI, S.; JAFARI, A.; ZAREPOUR, M. Distribution of virulence related genes among enteroaggregative Escherichia coli isolates: using multiplex PCR and hybridization. Infect. Genet. Evol., v. 5, p. 79-83, 2005. 
BUERIS, V.; SIRCILLI, M. C.; TADDEI, C. R.; SANTOS, M. F.; FRANZOLIN, M. R.; MARTINEZ, M. B.; FERRER, S. R.; BARRETI, M. L.; TRABULSI, L. R. Detection of Escherichia coli from children with and without diarrhea in Salvador, Bahia, Brazil. Mem. Inst. Oswaldo Cruz, v. 102, p. 839-844, 2007.

CAMPOS, L. C.; FRANZOLIN, M. R.; TRABULSI, L. R. Diarrheagenic Escherichia coli categories among the traditional enteropathogenic $E$. coli $O$ serogroups: a review. Mem. Inst. Oswaldo Cruz, v. 99, p. 545-552, 2004.

CERNA, J. F.; NATARO, J. P.; GARCIA-ESTRADA T. Multiplex PCR for detection of three plasmid-borne genes of enteroaggregative Escherichia coli strains. J. Clin. Microbiol., v. 41, p. 2138-2140, 2003.

CHAUDHURI, R. R.; SEBAIHIA, M.; HOBMAN, J. L.; WEBBER, M. A.; Leyton, D. L.; GOLDBERG, M. D.; CUNNINGHAM, A. F.; SCOTT-TUCKER, A.; FERGUSON, P. R.; THOMAS, C. M.; FRANKEL, G.; TANG, C. M.; DUDLEY, E. G.; ROBERTS, I. S.; RASKO, D. A.; PALLEN, M. J.; PARKHILL, J.; NATARO, J. P.; THOMSON, N. R.; HENDERSON, I. R. Complete genome sequence and comparative metabolic profiling of the prototypical enteroaggregative Escherichia coli strain 042. PLoS One, v. 5, e8801, 2010.

CLEMENTS, A.; YOUNG, J. C.; CONSTANTINOU, N.; FRANKEL, G. Infection strategies of enteric pathogenic Esherichia coli. Gut. Microbes, v. 3, p. 71-87, 2012.

COBELJIĆ, M.; MILJKOVIĆ-SELIMOVIĆ, B.; PAUNOVIĆ-TODOSIJEVIĆ, D.; VELICKOVIĆ, Z.; LEPSANOVIĆ, Z.; ZEC, N.; SAVIĆ, D.; ILIĆ, R.; KONSTANTINOVIĆ, S.; JOVANOVIĆ, B.; KOSTIĆ, V. Enteroaggregative Escherichia coli associated with an outbreak of diarrhoea in a neonatal nursery ward. Epidemiol. Infect., v. 117, p. 11-16, 1996.

COHEN, M. B.; NATARO, J. P.; BERNSTEIN, D. I.; HAWKINS, J.; ROBERTS, N.; STAAT, M. A. Prevalence of diarrheagenic Escherichia coli in acute childhood enteritis: a prospective controlled study. J. Pediatr., v. 146, p. 54-61, 2005.

COOKSON, S. T.; NATARO, J. P. Characterization of HEp-2 cell projection formation induced by diffusely adherent Escherichia coli. Microb. Pathog., v. 21, p. 421-434, 1996.

CORDEIRO, F.; PEREIRA D. S. G.; ROCHA, M.; ASSENSI, M. D; ELIAS, W. P.; CAMPOS, L. C. Evaluation of a multiplex PCR for identification of enteroaggregative Escherichia coli. J. Clin. Microbiol., v. 46, p. 828-829, 2008.

COSSART, P.; SANSONETTI, P. J. Bacterial invasion: the paradigms of enteroinvasive pathogens. Science, v. 304, p. 242-248, 2004.

CRAVIOTO, A.; TEllo, A.; NAVARRO, A.; RUIZ, J.; VILLAFÁN, H.; URIBE, F.; ESLAVA, C. Association of Escherichia coli HEp-2 adherence patterns with type and duration of diarrhea. Lancet, v. 337, p. 262-264, 1991. 
CREPIN, V. F.; SHAW, R.; ABE, C. M.; KNUTTON, S.; FRANKEL, G. Polarity of enteropathogenic Escherichia coli EspA filament assembly and protein secretion. J. Bacteriol., v. 187, p. 2881-2889, 2005.

CROXEN, M. A.; FINLAY, B. B. Molecular mechanisms of Escherichia coli pathogenicity. Nat. Rev. Microbiol., v. 8, p. 26-38, 2010.

CROWTHER, J. R. The ELISA guidebook. New Jersey: Humana Press, 2001. v. 149, cap. 8 p. 314-315.

CZECZULIN, J. R.; BALEPUR, S.; HICKS, S.; PHILLIPS, A.; HALL, R.; KOTHARY, M. H.; NAVARRO-GARCIA, F.; NATARO, J. P. Aggregative adherence fimbria II, a second fimbrial antigen mediating aggregative adherence in enteroaggregative Escherichia coli. Infect. Immun., v. 65, p. 4135-4145, 1997.

CZECZULIN, J. R.; WHITTAM, T. S.; HENDERSON, I. R.; NAVARRO-GARCIA, F.; NATARO, J. P. Phylogenetic analysis of enteroaggregative and diffusely adherent Escherichia coli. Infect. Immun., v. 67, p. 2692-2699, 1999.

DUDLEY, E. G.; ABE, C.; CHIGO, J. M.; LAROUR-LAMBERT, P.; HORMAZABAL, J. C.; NATARO, J. P. An Incl1 plasmid contributes to the adherence of the atypical enteroaggregative Escherichia coli strain C1096 to cultured cells and abiotic surfaces. Infect. Immun., v. 74 p. 2102-2114, 2006a.

DUDLEY, E. G; THOMSON, N. R.; PARKHILL, J.; MORIN, N. P.; NATARO, J. P. Proteomic and microarray characterization of the $\mathrm{AggR}$ regulon identifies a pheU pathogenicity island in enteroaggregative Escherichia coli. Mol. Microbiol., v. 61, p. 1267-1282, 2006b.

ElIAS, W. P.; SUZART, S.; TRABULSI, L. R.; NATARO, J. P.; GOMES, T. A. Distribution of aggA and aafA gene sequences among Escherichia coli isolates with genotypic or phenotypic characteristics, or both, of enteroaggregative E. coli. J. Clin. Microbiol., v. 48, p. 597-599, 1999.

ELIAS, W. P.; UBER, A. P.; TOMITA, S. K.; TRABULSI, L. R.; GOMES, T. A. T. Combinations of putative virulence markers in typical and variant enteroaggregative Escherichia coli strains from children with and without diarrhoea. Epidemiol. Infect., v. 129, p. 49-55, 2002.

ESLAVA, C.; NAVARRO-GARCIA, G.; CZECZULIN, J. R.; HENDERSON, I. R.; CRAVIOTO, A.; NATARO, J. P. Pet, na autotransporter enterotoxin from enteroaggregative Escherichia coli. Infect. Immun., v. 66, p. 3155-3163, 1998.

ESTRADA-GARCIA, T.; NAVARRO-GARCIA, F. Enteroaggregative Escherichia coli pathotype: a genetically heterogeneous emerging foodborne enteropathogen. FEMS Immunol. Med. Microbiol., v. 66, p. 281-298, 2012.

FANG, G. D.; LIMA, A.; MARTINS, C. V; NATARO, J. P.; GUERRANT, R. L. Etiology and epidemiology of persistent diarrhea in northeastern Brazil: a hospital-based, 
prospective, case-control study. J. Pediatr. Gastroenterol. Nutr., v. 21, p. 137-144, 1995.

FRANKEL, G.; PHILLIPS, A. D. Attaching effacing Escherichia coli and paradigms of Tir-triggered actin polymerization: getting off the pedestal. Cell. Microbiol., v. 10, p. 549-556, 2008.

FISCHER WALKER, C. L.; PERIN, J.; ARYEE, M. J.; BOSCHI-PINTO, C.; BLACK, R. E. Diarrhea incidence in low- and middle-income countries in 1990 and 2010: a systematic review. BMC Public. Health., v. 12, p. 220, 2012.

FOUHY, F.; ROSS, R. P.; FITZGERALD, G. F.; STANTON, C.; COTTER, P. D. Composition of the early intestinal microbiota: knowledge, knowledge gaps and the use of high-throughput sequencing to address these gaps. Gut. Microbes, v. 3, p. 203-220, 2012.

FUJIOKA, M.; KASAI, K.; MIURA, T.; SATO, T.; OTOMO, Y. Rapid diagnostic method for the detection of diarrheagenic Escherichia coli by multiplex PCR. Jpn. J. Infect. Dis., v. 62, p. 476-480, 2009.

FUJIYAMA, R; NISHI, J.; IMUTA, N.; TOKUDA, K.; MANAGO, K.; KAWANO, Y. The shf gene of Shigella flexneri homologue on the virulent plasmid pAA2 of enteroaggregative Escherichia coli 042 is required for firm biofilm formation. Curr. Microbiol., v. 56, p. 474-480, 2008.

GAASTRA, W.; SVENNERHOLM, A. M. Colonization factors of human enterotoxigenic Escherichia coli (ETEC). Trends Microbiol. v. 4, p. 444-452, 1996.

GARCIA, P. G.; SILVA, V. L.; DINIZ, C. G. Occurrence and antimicrobial drug susceptibility patterns of commensal and diarrheagenic Escherichia coli in fecal microbiota from children with and without acute diarrhea. J. Microbiol., v. 49, p. 46-52, 2011.

GIOPPO, N. M. R.; ELIAS, W. P.; VIDOTTO, M. C.; LINHARES, R. E.; SARIDAKIS, H. O.; GOMES, T. A. T.; TRABULSI, L. R.; PELAYO, J. S. Prevalence of HEp-2 celladherent Escherichia coli and characterization of enteroaggregative $E$. coli and chainlike adherent $E$. coli isolated from children with and without diarrhoea, in Londrina, Brazil. FEMS Microbiol. Lett., v. 190, p. 293-298, 2000.

GIRÓN, J. A.; DONNENBERG, M. S.; MARTIN, W. C.; JARVIS, K. G.; KAPER, J. B. Distribution of the bundle-forming pilus structural gene (bfpA) among enteropathogenic Escherichia coli. J. Infect. Dis., v. 168, p. 1037-1041, 1993.

GIRÓN, J. A.; JONES, T.; MILLÁN-VELASCO, F.; CASTRO-MUNOZ, E.; ZARATE, L.; FRY, J.; FRANKEL, G.; MOSELEY, S. L.; BAUDRY, B.; KAPER, J. B.; SCHOOLNIK, G. K.; RILEY, L. W. Diffuse-adhering Escherichia coli (DAEC) as a putative cause of diarrhea in Mayan children in Mexico. J. Infect. Dis., v. 163, p. 507-513, 1991. 
GOMES, T. A.; VIEIRA, M. A.; ABE, C. M.; RODRIGUES, D.; GRIFFIN, P. M.; RAMOS, S. R. Adherence patterns and adherence-related DNA sequences in Escherichia coli isolates from children with and without diarrhea in São Paulo city, Brazil. J. Clin. Microbiol., v. 36, p. 3609-3613, 1998.

GUIGNOT, J.; CHAPLAIS, C.; COCONNIER-POLTER, M. H.; SERVIN, A. L. The secreted autotransporter toxin, Sat, functions as a virulence factor in $\mathrm{Afa} / \mathrm{Dr}$ diffusely adhering Escherichia coli by promoting lesions in tight junction of polarized epithelial cells. Cell. Microbiol., v. 9, p. 204-221, 2007.

GUION, C. E.; OCHOA, T. J.; WALKER, C. M.; BARLETTA, F.; CLEARY, T. G. Detection of diarrheagenic Escherichia coli by use of melting-curve analysis and realtime multiplex PCR. J. Clin. Microbiol. v. 46, p. 1752-1757, 2008.

GUTH, B. E. C.; PICHETH, C. F.; GOMES, T. A. T. Escherichia coli situation in Brazil. In: TORRES, A. G. (Ed.). Pathogenic Escherichia coli in Lantim America. Oak Park: Bentham Science Publishers, 2010. cap. 11, p. 162-178. elSBN: 978-1-60805-192-2.

GUNZBURG, S. T.; CHANG, B. J.; ELLIOTT, S. J.; BURKE, V.; GRACEY, M. Diffuse and enteroaggregative patterns of adherence of enteric Escherichia coli isolated from aboriginal children from the Kimberley region of Western Australia. J. Infect. Dis., v. 67, p. $755-8,1993$.

HARADA, T.; HIROI, M.; KAWAMORI, F.; FURUSAWA, A.; OHATA, K.; SUGIYAMA, K.; MASUDA, T. A food poisoning diarrhea outbreak caused by enteroaggregative Escherichia coli serogroup 0126:H27 in Shizuoka, Japan. Jpn. J. Infect. Dis., v. 60, p. 154-155, 2007.

HARRINGTON, S. M.; DUDLEY, E. G.; NATARO, J. P. Pathogenesis of enteroaggregative Escherichia coli infection. FEMS Microbiol. Lett., v. 254, p. 12-18, 2006.

HENDERSON, I. R.; CZECZULIN, J.; ESLAVA, C.; NORIEGA, F.; NATARO, J. P. Characterization of pic, a secreted protease of Shigella flexneri and enteroaggregative Escherichia coli. Infect. Immun., v. 67, p. 5587-5596, 1999.

HERNANDES, R. T.; ELIAS, W. P.; VIEIRA, M. A. M.; GOMES, T. A.T. An overview of atypical enteropathogenic Escherichia coli. FEMS Microbiol. Lett., v. 297, p. 137-149, 2009.

HERNANDES, R. T.; VIEIRA, M. A. M.; CARNEIRO, S. M.; SALVADOR, F. A.; GOMES, T. A. T. Characterization of atypical enteropathogenic Escherichia coli strains that express typical localized aderence in HeLa cells in the absence of the bundleforming pilus. J. Clin. Microbiol., v. 44, p. 4214-4217, 2006.

HODGES, K.; GILL, R. Infectious diarrhea: cellular and molecular mechanisms. Gut. Microbes., v. 1, p. 4-21, 2010. 
HUANG, D. B.; JIANG, Z. D.; DUPONT, H. L. Association of virulence factor-positive and -negative enteroaggregative Escherichia coli and occurrence of clinical illness in travelers from the United States to Mexico. Am. J. Trop. Med. Hyg., v. 69, p. 506-508, 2003.

HUANG, D. B.; DUPONT, H. L. Enteroaggregative Escherichia coli: an emerging pathogen in children. Semin. Pediatr. Infect. Dis., v. 15, p. 266-271, 2004.

HUANG, D. B.; NATARO, J. P.; DuPONT, H. L.; KAMAT, P. P.; MHATRE, A. D.; OKHUYSEN, P. C.; CHIANG T. Enteroaggregative Escherichia coli as a cause of diarrheal illness: a meta-analysis. Clin. Infect. Dis., v. 43, p. 556-563, 2006.

HUANG, D. B.; MOHAMED, J. A.; NATARO, J. P.; DUPONT, H. L.; JIANG, Z. D.; OKAHUYSEN, P. C. Virulence characteristics and molecular epidemiology of enteroaggregative Escherichia coli isolates from travellers to developing countries. J. Med. Microbiol., v. 56, p. 1386-1392, 2007.

HUNT, J. M. Shiga toxin-producing Escherichia coli (STEC). Clin. Lab. Med., v. 30, p. 21-45, 2010.

INSTITUTO BRASILEIRO DE GEOGRAFIA E ESTATÍSTICA. Pesquisa nacional por amostra de domicílios. v. 31, p. 1-135, 2011.

ISIDEAN, S. D.; RIDDLE, M. S.; SAVARINO, S. J.; PORTER, C. K. A systematic review of ETEC epidemiology focusing on colonization factor and toxin expression. Vaccine, $v$. 29, p. 6167-6178, 2011.

ITOH, Y.; NAGANO, I.; KUNISHIMA, M.; EZAKI, T. Laboratory investigation of enteroaggregative Escherichia coli $\mathrm{O}$ untypeable: $\mathrm{H} 10$ associated with a massive outbreak of gastrointestinal illness. J. Clin. Microbiol., v. 35, p. 2546-2550, 1997.

JENKINS, C.; CHART, H.; WILLSHAW, A.G.; CHEASTY, T.; SMITH, H.R. Genotyping of enteroaggregative Escherichia coli and identification of target genes for the detection of both typical and atypical strains. Diag. Microbiol. Infect. Dis., v. 55, p.13-19, $2006 a$.

JENKINS, C.; TEMBO, M.; CHART, H.; CHEASTY, T.; WILLSHAW, G. A.; PHILLIPS, A. D.; SMITH, H. Detection of enteroaggregative Escherichia coli in faecal samples from patients in the community with diarrhea. J. Med. Microbiol., v. 55, p. 1493-1497, 2006b.

JIANG, Z. D.; GREENBERG, D.; NATARO, J. P.; STEFFEN, R.; DUPONT, H. L. Rate of occurrence and pathogenic effect of enteroaggregative Escherichia coli virulence factors in intestinal travelers. J. Clin. Microbiol., v. 40, p. 4185-4190, 2002.

JOHNSON, T. J.; NOLAN, L. K. Pathogenomics of the virulence plasmids of Escherichia coli. Microbiol. Mol. Biol. Rev., v. 73, p. 750-774, 2009.

KAPER, J. B. Defining EPEC. Rev. Microbiol., v. 27, p. 130-133, 1996. 
KAPER, J. B.; NATARO, J. P.; MOBLEY, H. L. T. Pathogenic Escherichia coli. Nat. Rev., v. 2, p. 123-140, 2004.

KARMALI, M. A.; GANNON, V.; SARGEANT, J. M. Verocytotoxin-producing Escherichia coli (VTEC). Vet. Microbiol., v.140, p. 360-370, 2010.

KNUTTON, S. R.; SHAW, A. D.; PHILLIPS, H. R.; SMITH, G. A.; WILLSHAW, P.; WATSON, E. P. Phenotypic and genetic analysis of diarrhea-associated Escherichia coli isolated from children in the United Kingdom. J. Pediatr. Gastroenterol. Nutr., v. 33 p. 32-40, 2001.

LE BOUGUÉNEC, C.; SERVIN, A. L. Diffusely adherent Escherichia coli strains expressing Afa/Dr adhesins (Afa/Dr DAEC): hitherto unrecognized pathogens. FEMS Microbiol. Lett., v. 256, p. 185-194, 2006.

LEVY, E. C.; VAZ, T. M. Enterobactérias. In: AGÊNCIA NACIONAL DE VIGILÂNCIA SANITÁRIA. Microbiologia Clínica para o controle de infecção relacionada à assistência à saúde. Brasília, 2010. cap. 3, p. 35-58. Disponível em: <www.anvisa.gov.br>. Acesso em: 20 jun. 2013.

LIMA, I. F.; BOISEN, N.; QUETZ, J. S.; HAVT, A.; DE CARVALHO, E. B.; SOARES, A. M.; LIMA, N. L.; MOTA, R. M.; NATARO, J. P.; GUERRANT, R. L.; LIMA, A. A. Prevalence of enteroaggregative Escherichia coli and its virulence-related genes in a case-control study among children from north-eastern Brazil. J. Med. Microbiol., v. 62, p. 683-6, 2013a.

LIMA, I. F.; QUETZ, J. D. A. S.; GUERRANT, R. L.; NATARO, J. P.; HOUPT, E. R.; LIMA, A. A.; HAVT, A. Enteroaggregative Escherichia coli quantification in children stool samples using quantitative PCR. APMIS., v. 121, p. 643-651, 2013b.

LIMA, A. A.; FANG, G.; SHORLING, J. B.; DE ALBUQUERQUE, L.; MCAULIFFE, J. J.; MOTA, S.; LEITE, R.; GUERRANT, R. L. Persistent diarrhea in northeast Brazil: etiologies and interactions with malnutrition. Acta Pediatr. Suppl., v. 381, p. 37-44, 1992.

MAIRENA, E. C.; NEVES B. C.; TRABULSI L. R.; ELIAS, W. P. Detection of LEE 4 region-encoded genes from different enteropathogenic and enterohemorrhagic Escherichia coli serotypes. Curr. Microbiol., v. 48, p. 412-418, 2004.

MARQUES, L. R.; ABE, C. M.; GRIFFIN, P. M.; GOMES, T. A. Association between alpha-hemolysin production and HeLa cell-detaching activity in fecal isolates of Escherichia coli. J. Clin. Microbiol., v. 33 p. 2707-2709, 1995.

MARTINEZ, M. B.; WHITTAM, T. S.; MCGRAW, E. A.; RODRIGUES, J.; TRABULSI, L. R. Clonal relationships among invasive and non-invasive strains of enteroinvasive Escherichia coli serogroups. FEMS Microbiol. Lett., v. 172, p. 145-151, 1999.

MATHEWSON, J. J.; JIANG, Z. D.; ZUMLA, A.; CHINTU, C.; LUO, N.; CALAMARI, S. R.; GENTA, R. M.; STEEPHEN, A.; SCHWARTZ, P.; DUPONT, H. L. HEp-2 cell- 
adherent Escherichia coli in patients with human immunodeficiency virus-associated diarrhea. J. Infect. Dis., v. 171, p. 1636-1639, 1995.

McDANIEL, J. K.; JARVIS, K. G.; DONNENBERG, M. S.; KAPER, J. B. A genetic locus of enterocyte effacement conserved among diverse enterobacterial pathogens. Proc. Natl. Acad. Sci. U. S. A., v. 92, p. 1664-1668, 1995.

MENEZES, C. A.; IMAMURA, S. Y.; TRABULSI, L. R.; FERNANDES-FILHO, A.; MARTINEZ, M. B.; GUTH, B. E. C.; GIRÃO, D. M.; PIAZZA, R. M. F. Production, characterization, and application of antibodies against heat-labile type-I toxin (LT-I) for detection of enterotoxigenic Escherichia coli. Mem. Inst. Oswaldo Cruz, v. 101, p. 875880, 2006.

MIQDAY, M. S.; JIANG, Z. D.; NATARO, J. P.; DUPONT, H.L. Detection of enteroaggregative Escherichia coli with formalin-preserved HEp-2 cells. J. Clin. Microbiol., v. 40, p. 3066-3067, 2002.

MOHAMED, J. A.; HUANG, D. B.; JIANG, Z. D.; DUPONT, H. L.; NATARO, J. P.; BELKIND-GERSON, J.; OKHUYSEN, P. C. Association of putative enteroaggregative Escherichia coli virulence genes and biofilm production in isolates from travelers to developing countries. J. Clin. Microbiol., v. 45, p. 121-126, 2007.

MONTEIRO, B .T.; CAMPOS, L. C.; SIRCILI P. M.; FRANZOLIN M. R.; BEVILACQUA, L. F.; NATARO, J. P.; ELIAS, W. P. The dispersin-encoding gene (aap) is not restricted to enteroaggregative Escherichia coli. Diag. Microbiol. Infect. Dis., v. 65, p. 81-84, 2009.

MONFRADINI, M. V. Caracterização Genotípica e Fenotípica de Amostras de Escherichia coli Enteroagregativa (EAEC) e com Padrão Chain-like adhesion (CLA) de Crianças com e sem Diarreia. 2012. 96f. Dissertação (Mestrado em Doenças Infecciosas). Universidade Federal do Espírito Santo. UFES.

MOON, H. W.; WHIPP, S. C.; ARGENZIO, R. A.; LEVINE, M. M.; GIANNELLA, R. A. Attaching and effacing activities of rabbit and human enteropathogenic Escherichia coli in pig and rabbit intestines Infect. Immun., v. 41, p. 1340-1351, 1983.

MORAIS, T. B.; GOMES, T. A.; SIGULEM, D. M. Enteroaggregative Escherichia coli in infant feeding bottles. Lancet. v. 349 p. 1448-1449, 1997.

MORENO, A. C. R.; FERNANDES-FILHO, A.; GOMES, T. A. T.; RAMOS, S. T. S.; MONTEMOR, L. P. G.; TAVARES, V. C.; SANTOS-FILHO, L.; IRINO, K.; MARTINEZ, M. B. Etiology of childhood diarrhea in the northeast of Brazil: significant emergent diarrheal pathogens. Diag. Microbiol. Infect. Dis., v. 66, p. 50-57, 2010.

MORIN, N.; SANTIAGO, A. E.; ERNST, R. K.; GUILLOT S. J.; NATARO, J. P. Characterization of the AggR Regulon in enteroaggregative E. coli. Infect. Immun., v. 81, p. 122-132, 2012. 
MOSAMMAPARAST, N.; MCADAM, A. J.; NOLTE, F. S. Molecular testing for infectious diseases should be done in the clinical microbiology laboratory. J. Clin. Microbiol., v. 50, p. 1836-1840, 2012.

MÜLLER, D.; GREUNE, L.; HEUSIPP, G.; KARCH， H.; FRUTH， A.; TSCHÄPE, H.; Identification of unconventional intestinal pathogenic Escherichia coli isolates expressinginterme diate virulence factor profiles by using a novel single-step multiplex PCR. Appl Environ. Microbiol., v. 73, p. 3380-3390, 2007.

MUNIESA, M.; HAMMERL, J. A.; HERTWIG, S.; APPEL, B.; BRÜSSOW, H. Shiga toxin-producing Escherichia coli: a new challenge for microbiology. Appl. Environ. Microbiol., v. 78, p. 4065-4073, 2012.

NATARO, J. P. Enteroaggregative Escherichia coli pathogenesis Curr. Opin. Gastroenterol., v. 21, p. 4-8, 2005.

NATARO, J. P.; KAPER, J. B. Diarrheagenic Escherichia coli. Clin. Microbiol. Rev., v. 11, p. 142-201, 1998.

NATARO, J. P.; DENG, Y.; COOKSON, S.; CRAVIOTO, A.; SAVARINO, S. J.; GUERS, L. D.; LEVINE, M. M.; TACKET, C. O. Heterogeneity of enteroaggregative Escherichia coli virulence demonstrated in volunteers. J. Infect. Dis., v. 171, p. 465-468, 1995.

NATARO, J. P.; YIKANG, D.; YINGKANG, D.; WALKER, K. AggR, a transcriptional activator of enteroaggregative adherence fimbria I expression in enteroaggregative adherence fimbria I expression in enteroaggregative Escherichia coli. J. Bacteriol., v. 176, p. 4691-4699, 1994.

NATARO, J. P.; DENG, Y.; MANEVAL, D. R.; GERMAN, A. L.; MARTIN, W. C.; LEVINE, M. M. Aggregative adherence fimbriae I of enteroaggregative Escherichia coli mediate adherence to HEp-2 cells and hemagglutination of human erythrocytes. Infect. Immun., v. 60, p. 2297-2304, 1992.

NATARO, J. P.; BALDINI, M. M.; KAPER, J. B.; BLACK, R. E.; BRAVO, N.; LEVINE, M. $M$. Detection of an adherence factor of enteropathogenic Escherichia coli with a DNA probe. J. Infect. Dis., v. 152, p. 560-565, 1985.

NATARO, J. P.; KAPER, J. B.; ROBINS-BROWNE, E.; PRADO, V.; VIAL, P. A.; LEVINE, M. M. Patterns of adherence of diarrheagenic Escherichia coli to HEp-2 cells. Pediatr. Infect. Dis. J., v. 16, p. 829-831, 1987.

NAVARRO-GARCIA, F.; ELIAS, W. P. Autotransporters and virulence of enteroaggregative Escherichia coli. Gut. Microbes, v. 2, p. 13-24, 2011.

NAVARRO-GARCIA, F.; ELIAS, W. P.; FLORES, J.; OKHUYSEN, P. C. Enteroaggregative Escherichia coli. In: TORRES, A. G. (Ed.). Pathogenic Escherichia coli in Latin America. Oak Park: Bentham Science Publishers, 2010. cap. 4, p. 48-64. elSBN: 978-1-60805-192-2. 
NAVARRO-GARCÍA, F.; ESLAVA, C.; VILLASECA, J. M.; LÓPEZ-REVILLA, R.; CZECZULIN, J. R.; SRINIVAS, S.; NATARO, J. P.; CRAVIOTO, A. In vitro effects of a high-molecular-weight heat-labile enterotoxin from enteroaggregative Escherichia coli. Infect. Immun., v. 66 p. 3149-3154, 1998.

NGUYEN, Y.; SPERANDIO, V. Enterohemorrhagic E. coli (EHEC) pathogenesis. Front. Cell. Infect. Microbiol., v. 2, p. 1-7, 2012.

NGUYEN, T. V.; VAN, P. L.; HUY, C. L.; NGUYEN-GIA, K.; WEINTRAUB, A. Detection and characterization of diarrheagenic Escherichia coli from young children in Hanoi, Vietnam. J. Clin. Microbiol., v.43, p. 755-760, 2005.

NISHI, J.; SHEIKH, J.; MIZUGUCHI, K.; LUISI, B.; BURLAND, V.; BOUTIN, A.; ROSE, D. J.; BLATTNER, F. R.; NATARO, J. P. The export of coat protein from enteroaggregative Escherichia coli by a specific ATP-binding cassette transporter system. J. Biol. Chem., v. 278, p. 45680-45689, 2003.

OCHOA, T. J.; CONTRERAS, C. A. Enteropathogenic E. coli (EPEC) infection in children. Curr. Opin. Infect. Dis., v. 24, p. 478-483, 2011.

OCHOA, T. J.; BARLETTA, F.; CONTRERAS, C.; MERCADO, E. New insights into the epidemiology of enteropathogenic Escherichia coli infection. Trans. R. Soc. Trop. Med. Hyg., v. 102, p. 852-856, 2008.

OKEKE, I. N. Diarrheagenic Escherichia coli in sub-Saharan Africa: status, uncertainties and necessities. J. Infect. Dev. Ctries., v. 3, p. 817-842, 2009.

OKEKE, I. N.; OJO, O.; LAMOKANRA, A.; KAPER, J. B. Etiology of acute diarrhea in adults in southwestern Nigeria. J. Clin. Microbiol., v. 41, p. 4525-4230, 2003.

OKEKE, I. N.; LAMIKANRA, A.; STEINRÜCK, H.; KAPER, J. B. Characterization of Escherichia coli strains from cases of childhood diarrhea in provincial southwestern Nigeria. J. Clin. Microbiol., v. 38, p. 7-12, 2000.

OLIVEIRA, T. C. R.; LATORRE, M. R. D. O. Tendências da internação e da mortalidade infantil por diarreia: Brasil, 1995 a 2005. Rev. Saúde Pública, v. 44, p. 102-111, 2010.

PANCHALINGAM, S.; ANTONIO, M.; HOSSAIN, A.; MANDOMANDO, I.; OCHIENG, B.; OUNDO, J.; RAMAMURTHY, T.; TAMBOURA, B.; ZAIDI, A. K.; PETRI, W.; HOUPT, E.; MURRAY, P.; PRADO, V.; VIDAL, R.; STEELE, D.; STROCKBINE, N.; SANSONETTI, P.; GLASS, R. I.; ROBINS-BROWNE, R. M.; TAUSCHEK, M.; SVENNERHOLM, A. M.; KOTLOFF, K.; LEVINE, M. M.; NATARO, J. P. Diagnostic microbiologic methods in the GEMS-1 case/control study. Clin. Infect. Dis., v. 55, Suppl 4, S294-302, 2012.

PARSOT, C. Shigella spp. and enteroinvasive Escherichia coli pathogenicity factors. FEMS Microbiol. Lett., v. 252, p. 11-18, 2005.

PEREIRA, A. L.; FERRAZ, $\quad$ L. $\quad$ R.; SILVA, R. S.; GIUGLIANO, L. G. Enteroaggregative Escherichia coli virulence markers: positive association with distinct 
clinical characteristics and segregation into 3 enteropathogenic E. coli serogroups. J. Infect. Dis., v. 195, p. 366-374, 2007.

PETRI, W. A.; MILLER, M.; BINDER, H. J.; LEVINE, M. M.; DILLINGHAM, R.; GUERRANT, R. L. Enteric infections, diarrhea, and their impact on function and development. J. Clin. Invest., v. 118, p. 1277-1290, 2008.

PIVA, I. C.; PEREIRA, A. L.; FERRAZ, L. R.; SILVA, R. S. N.; VIEIRA, A. C.; BLANCO, J. E.; BLANCO, M.; BLANCO, J.; GIUGLIANO, L. G. Virulence markers of enteroagregative Escherichia coli from children and adults with diarrhea in Brasília, Brazil. J. Clin. Microbiol., v. 41, p. 1827-1832, 2003.

POLITO, M. G.; KIRZTAJN, G. M. Microangiopatias trombóticas: púrpura trombocitopênica trombótica e síndrome hemolítico-urêmica. J. Bras. Nefr., v. 32, p. 303-315, 2010.

PUKATZKI, S.; MA, A. T.; STURTEVANT, D.; KRASTINS, B.; SARRACINO, D.; NELSON, W. C.; HEIDELBERG, J. F.; MEKALANOS, J. J. Identification of a conserved bacterial protein secretion system in Vibrio cholerae using the Dictyostelium host model system. Proc. Natl. Acad. Sci. U. S. A., v. 103 p. 1528-1533, 2006.

QADRI, F.; SVENNERHOLM, A. M.; FARUQUE, A. S. G.; SACK, R. B. Enterotoxigenic Escherichia coli in developing countries: epidemiology, microbiology, clinical features, treatment and prevention. Clin. Microbiol. Rev., v. 18, p. 465-483, 2005.

RASKO, D. A.; WEBSTER, D. R; SAHL, J. W.; BASHIR, A.; BOISEN, N.; SCHEUTZ, F.; PAXINOS, E. E.; SEBRA, R.; CHIN, C. S.; ILIOPOULOS, D.; KLAMMER A.; PELUSO, P.; LEE, L.; KISLYUK, A. O.; BULLARD, J.; KASARSKIS, A.; WANG, S.; EID, J.; RANK, D.; REDMAN, J. C.; STEYERT, S. R.; FRIMODT-MØLLER, J.; STRUVE, C.; PETERSEN, A. M.; KROGFELT, K. A.; NATARO, J. P.; SCHADT, E. E.; WALDOR, M. $\mathrm{K}$. Origins of the Escherichia coli strain causing an outbreak of hemolytic-uremic syndrome in Germany. N. Engl. J. Med., v. 365, p. 709-717, 2011.

REGUA-MANGIA, A. H.; GOMES, T. A. T.; VIEIRA, M. A. M.; ANDRADE, J. R.; IRINO, K.; TEIXEIRA, L. M. Frequency and characteristics of diarrhoeagenic Escherichia coli strains isolated from children with and without diarrhoea in Rio de Janeiro, Brazil. J. Infect., v. 48, p. 161-167, 2004.

RILEY, L. W.; REMIS, R. S.; HELGERSON, S. D.; MCGEE, H. B.; WELLS, J. G.; DAVIS, B. R.; HEBERT, R. J.; OLCOTT, E. S.; JONHSON, L. M.; HARGRETT, N. T.; BLAKE, P. A.; COHEN, M. L. Hemorragic colitis associated with a rare Escherichia coli serotype. N. Engl. J. Med., v. 308, p. 681-685, 1983.

ROBINS-BROWNE, R. M.; BORDUN, A. M.; TAUSCHEK, M.; BENNETT-WOOD, V. R.; RUSSEL, J.; OPPEDISANO, F.; LISTER, N. A.; BETTELHEIM, K. A.; FAIRLEY, C. K.; SINCLAIR, M. I.; HELLARD, M. E. Escherichia coli and community-acquired gastroenteritis, Melbourne, Australia. Emerg. Infect. Dis., v. 10, p. 1797-1805, 2004. 
ROCHA, L. B. Desenvolvimento e padronização de testes imunocromatográficos para diagnóstico de Escherichia coli produtora da toxina de Shiga (STEC) e Escherichia coli enterotoxigênica (ETEC). 158 f. 2012. Tese (Doutorado em Biotecnologia) - Instituto de Ciências Biomédicas, Universidade de São Paulo, São Paulo, 2012.

RODRIGUES, J.; ACOSTA, V. C.; CANDEIAS, J. M.; SOUZA, L. O.; FILHO, F. J. Prevalence of diarrheogenic Escherichia coli and rotavirus among children from Botucatu. Braz. J. Med. Biol. Res., v. 35, p. 1311-1318, 2002.

RODRIGUES, J.; SCALETSKY, I. C.; CAMPOS, L. C.; GOMES, T. A.; WHITTAM, T. S.; TRABULSI, L. R. Clonal structure and virulence factors in strains of Escherichia coli of the classic serogroup O55. Infect. Immun., v. 64, p. 2680-2686, 1996.

RUSSO, T. A.; JOHNSON, J. R. Proposal for a new inclusive designation for extraintestinal pathogenic isolates of Escherichia coli: ExPEC. J. Infect. Dis., v. 181, p. 1753-1754, 2000.

RÜTTLER, M. E.; YANZÓN, C. S.; CUTTIÑO, M. J.; RENNA, N. F.; PIZARRO, M. A.; ORTIZ, A. M. Evaluation of multiplex PCR method to detect enteroaggregative Escherichia coli. Biocellular, v. 30, p. 301-308, 2006.

SAMBROOK, J.; FRITSCH, E. F.; MANIATIS, T. Molecular Cloning: a Laboratory Manual. New York: Cold Spring Harbor, 1989.

SAMIE, A.; OBI, C. L.; DILLINGHAM, R.; PINKERTON, R. C.; GUERRANT, R. L. Enteroaggregative Escherichia coli in Venda, South Africa: distribution of virulencerelated genes by multiplex polymerase chain reaction in stool samples of human immunodeficiency virus (HIV)-positive and HIV-negative individuals and primary school children. Am. J. Trop. Med. Hyg., v. 77, p. 142-150, 2007.

SARANTUYA, J.; NISHI, J.; WAKIMOTO, N.; ERDENE, S.; NATARO, J. P.; SHEIKH, J.; IWASHITA, M.; MANAGO, K.; TOKUDA, K.; YOSHINAGA, M.; MIYATA, K.; KAWANO, Y. Typical enteroaggregative Escherichia coli is the most prevalent pathotype among E. coli strains causing diarrhea in Mongolian children. J. Clin. Microbiol., v. 42, p. 133-139, 2004.

SAVARINO, S. J.; MCVEIGH, A.; WATSON, J.; MOLINA, J.; CRAVIOTO, A.; ECHEVERRIA, P.; BHAN, M. K.; LEVINE, M. M.; FASANO, A. Enteroaggregative Escherichia coli heat-stable enterotoxin is not restricted to enteroaggregative Escherichia coli. J. Infect. Dis., v. 173, p. 1019-1022, 1996.

SAVARINO, S. J.; FASANO, A; WATSON, J.; MARTIN, B. M.; LEVINE, M. M.; GUANDALINI, S.; GUERRY, P. Enteroaggregative Escherichia coli heat-stable enterotoxin 1 represents another subfamily of E. coli heat-stable toxin. Proc. Natl. Acad. Sci. U.S.A., v. 90, p. 3093-3097, 1993. 
SAVARINO, S. J.; FOX, P.; DENG, Y.; NATARO, J. P. Identification and characterization of a gene cluster mediating enteroaggregative Escherichia coli aggregative adherence fimbria I biogenesis. J. Bacteriol., v. 176 p. 4949-4957, 1994.

SAVARINO, S. J.; FASANO, A.; ROBERTSON, D. C.; LEVINE, M. M. Enteroaggregative Escherichia coli elaborate a heat-stable enterotoxin demonstrable in an in vitro rabbit intestinal model. J. Clin. Invest., v. 87, p. 1450-1455, 1991.

SCALETSKY, I. C. A.; FABBRICOTI, S. H.; SILVA, S. O.; MORAIS, M. B.; FAGUNDESNETO, U. HEp-2-adherent Escherichia coli strains associated with acute diarrhea, São Paulo, Brazil. Emerg. Infect. Dis., v. 8, p. 855-858, 2002.

SCALETSKY, I. C. A.; PEDROSO, M. Z.; OLIVA, C. A.; CARVALHO, R. L.; MORAIS, M. B.; FAGUNDES-NETO, U. A localized adherence pattern as a second pattern of adherence of classic enteropathogenic Escherichia coli to HEp-2 cells that is associated with infantile diarrhea. Infect. Immun., v. 67, p. 3410-3415, 1999.

SCALETSKY, I. C. A.; SILVA, M. L. M.; TRABULSI, L. R. Distinctive patterns of adherence of enteropathogenic Escherichia coli to HeLa cells. Infect. Immun., v. 45, p. 534-536, 1984.

SCHMIDT, H.; KNOP, C.; FRANKE, S.; ALESKIC, S.; HEESEMANN, J.; KARCH, H. Development of PCR for screening of enteroaggregative Escherichia coli. J. Clin. Microbiol., v. 33, p. 701-705, 1995.

SHEIKH, J.; DUDLEY, E. G.; SUI, B.; TAMBOURA, B.; SULEMAN, A.; NATARO, J. P. EilA, a HilA-like regulator in enteroaggregative Escherichia coli. Mol. Microbiol., v. 61, p. 338-350, 2006.

SHEIKH, J.; CZECZULIN, J. R.; HARRINGTON, S.; HICKS, S.; HENDERTON, I. R.; LE BOUGUÉNEC, C.; GOUNON, P.; PHILLIPS, A.; NATARO, J. P. A novel dispersin protein in enteroaggregative Escherichia coli. J. Clin. Invest., v. 110, p. 1329-1337, 2002.

SMITH, H. R.; CHEASTY, T.; ROWE, B. Enteroaggregative Escherichia coli and outbreaks of gastroenteritis in UK. Lancet, v. 350, p. 814-815, 1997.

SOBEL, J.; GOMES, T. A.; RAMOS, R. T.; HOEKSTRA, M.; RODRUIGUE, D.; RASSI, V.; GRIFFIN, P. M. Pathogen-specific risk factors and protective factors for acute diarrheal illness in children aged 12-59 months in São Paulo, Brazil. Clin. Infect. Dis., v. 38 p. 1545-1551, 2004.

SOUZA, T. B; LOZER, D. M; KITAGAWA, S. M.; SPANO, L. C.; SILVA, N. P.; SCALETSKY, I. C. Real-time multiplex PCR assay and melting curve analysis for identifying diarrheagenic Escherichia coli. J. Clin. Microbiol., v. 51, p.1031-1033, 2013.

SPANGLER, B. D. Structure and function of cholera toxin and the related Escherichia coli heat-labile enterotoxin. Microbiol. Rev., v. 56, p. 622-647, 1992. 
SPANO, L. C.; SADOVSKY, A. D. I.; SEGUI, P. N.; SAICK, K. E.; KITAGAWA, S. M. S.; PEREIRA, F. E. L.; FAGUNDES-NETO, U.; SCALETSKY, I. C. A. Age-specific prevalence of diffusely adherent Escherichia coli in Brazilian children with acute diarrhea. J. Med. Microbiol., v. 57, p. 359-363, 2008.

TADDEI, C. R.; MORENO A. C. R.; FERNANDES-FILHO A.; MONTEMOR L. P. G.; MARTINEZ, M. B. Prevalence of secreted autotransporter toxin gene among diffusely adhering Escherichia coli isolated from stools of children. FEMS Microbiol. Lett., v. 227, p. 249-253, 2003.

TANIUCHI, M.; WALTES, C. C.; GRATZ, J; MARO, A.; KUMBURU, H.; SERICHANTALERGS, O.; SETHABUTR, O.; BODHIDATTA, L.; KIBIKI, G.; TONEY, D. M.; BERKELEY, L.; NATARO, J. P.; HOUPT, E. R. Development of a multiplex polymerase chain reaction assay for diarrheagenic Escherichia coli and Shigella spp. and its evaluation on colonies, culture broths, and stool. Diagn. Microbiol. Infect. Dis., v. 73, p. 121-128, 2012.

TOMA, C.; LU, Y.; HIGA, N.; NAKASONE, N.; CHINEN, I.; BASCHKIER, A.; RIVAS, M.; IWANAGA, M. Multiplex PCR assay for identification of human diarrheagenic Escherichia coli. J. Clin. Microbiol., v. 41, p. 2669-2671, 2003.

TRABULSI, L. R.; KELLER, R.; GOMES, T. A. T. Typical and atypical enteropathogenic Escherichia coli. Emerg. Infect. Dis., v. 8, p. 508-513, 2002.

TURNER, S. M.; SCOTT-TUCKER, A.; COOPER, L. M.; HENDERSON, I. R. Weapons of mass destruction: virulence factors of the global killer enterotoxigenic Escherichia coli. FEMS Microbiol. Lett., v. 263, p. 10-20, 2006.

UNITED NATIONS CHILDREN'S FUND; WORLD HEATTH ORGANIZATION.

Diarrhoea: why children are still dying and what can be done, 2009. Disponível em:

<http://www.who.int/maternal_child_adolescent/documents/9789241598415/en/index.ht $\mathrm{ml}$. Acesso em: 15 nov. $201 \overline{2}$.

VASCONCELLOS, F. M. Padrão de adesão agregativa e formação de biofilme em Escherichia coli enteroagregativa típica e atípica: papel da proteína Shf. 2009. 96 f. Dissertação (Mestrado em Microbiologia) - Instituto de Ciências Biomédicas Universidade de São Paulo, São Paulo, 2009.

VELARDE, J. J.; VARNEY, K. M.; INMAN, K. G.; FARFAN, M.; DUDDLEY, E.; FLETCHER, J.; WEBER, D. J.; NATARO, J. P. Solution structure of the novel dispersin protein of enteroaggregative Escherichia coli. Mol. Microbiol., v. 66, p. 1123-1135, 2007.

VIDAL, J. E.; CANIZÁLEZ-ROMÁN, A.; GUTIÉRREZ-JIMÉNEZ, J.; NAVARROGARCIA, F. Molecular pathogenesis, epidemiology and diagnosis of enterophathogenic Escherichia coli. Salud. Publica Mex., v. 49, p. 376-386, 2007. 
VILA, J.; VARGAS, M.; HENDERSON, I. R.; GASCÓN, J.; NATARO, J. P. Enteroaggregative Escherichia coli virulence factors in traveler's diarrhea strains. J. Infect. Dis., v.182, p. 1780-1783, 2000.

VILLASECA, J. M.; NAVARRO-GARCÍA, F.; MENDOZA-HERNÁNDES, G.; NATARO, J. P.; CARVIOTO, A.; ESLACA, C. Pet toxin from enteroaggregative Escherichia coli produces cellular damage associated with fodrin disruption. Infect. Immun., v. 68, p. 5920-5927, 2000.

WINFIELD, M. D.; GROISMAN, E. A. Role of nonhost environments in the lifestyles of Salmonella and Escherichia coli. Appl. Environ. Microbiol., v. 69 p. 3687-94, 2003.

WORLD HEALTH ORGANIZATION. Improving diarrhea estimates. Child and adolescent health and development. Geneva, 2009.

YAMAMOTO, T.; KOYAMA, Y.; MATSUMOTO, M.; SONODA, E.; NAKAYAMA, S.; UCHIMURA, M.; PAVEENKITTIPORN, W.; TAMURA, K.; YOKOTA, T.; ECHEVERRIA, P. Localized, aggregative, and diffuse adherence to HeLa cells, plastic, and human small intestines by Escherichia coli isolated from patients with diarrhea. J. Infect. Dis., v. 166, p. 1295-12310, 1992.

ZAMBONI, A.; FABRICOTTI S. H.; FAGUNDES-NETO, U.; SCALETSKY, I. C. A. Enteroaggregative Escherichia coli virulence factors are found to be associated with infantile diarrhea in Brazil. J. Clin. Microbiol., v. 42, p. 1058-1063, 2004. 